\title{
Layered Double Hydroxide (LDH) Based Photocatalysts: An Outstanding Strategy for Efficient Photocatalytic $\mathrm{CO}_{2}$ Conversion
}

\author{
Abdul Razzaq ${ }^{1}$, Shahzad Ali ${ }^{1,2}$, Muhammad Asif ${ }^{1}$ and Su-Il In ${ }^{2, *(1)}$ \\ 1 Department of Chemical Engineering, COMSATS University Islamabad, Lahore Campus, \\ 1.5 KM Defence Road, Off Raiwind Road, Lahore 54000, Pakistan; abdulrazzaq@cuilahore.edu.pk (A.R.); \\ shahzadali@dgist.ac.kr (S.A.); asufarooq@gmail.com (M.A.) \\ 2 Department of Energy Science \& Engineering, DGIST, 333 Techno Jungang-daero, Hyeonpung-eup, \\ Dalseong-gun, Daegu 42988, Korea \\ * Correspondence: insuil@dgist.ac.kr; Tel.: +82-53-785-6417
}

Received: 15 September 2020; Accepted: 9 October 2020; Published: 14 October 2020

\begin{abstract}
CO}_{2}$ conversion to solar fuels/chemicals is an alluring approach for narrowing critical issues of global warming, environmental pollution, and climate change, caused by excess atmospheric $\mathrm{CO}_{2}$ concentration. Amongst various $\mathrm{CO}_{2}$ conversion strategies, photocatalytic $\mathrm{CO}_{2}$ conversion (PCC) is considered as a promising approach, which utilizes inexpensive sunlight and water with a photocatalyst material. Hence, development of an efficient and a stable photocatalyst is an essential activity for the respective scientific community to upscale the PCC research domain. Until today, metal oxides, such as $\mathrm{TiO}_{2}, \mathrm{ZnO}$, etc., are categorized as standard photocatalysts because of their relative stability, abundant availability and low cost. However, their performance is tethered by limited light absorption and somewhat physical properties. Recently, layered double hydroxides (LDHs) have offered an exciting and efficient way for PCC due to their superb $\mathrm{CO}_{2}$ adsorption and moderate photocatalytic properties. The LDH based photocatalysts show marvelous physiochemical and electrical properties like high surface area, stability, and excellent conductivity. In the present review article, a summarized survey is portrayed regarding latest development for LDH based photocatalysts with a focus on synthesis strategies employing various photocatalyst materials, influencing parameters and possible mechanism involved in PCC to useful fuels and chemicals like $\mathrm{CO}, \mathrm{CH}_{4}, \mathrm{CH}_{3} \mathrm{OH}$, and $\mathrm{H}_{2}$.
\end{abstract}

Keywords: layered double hydroxide; photocatalytic $\mathrm{CO}_{2}$ conversion; surface modifications; composite nanostructures; $\mathrm{CO}_{2}$ conversion mechanism

\section{Introduction}

Ever increasing energy demand for rapid industrialization/urbanization, being fulfilled mainly from fossil fuels, is continuously stimulating the alarming and severe threats of environmental pollution and global warming [1]. It is believed that amongst various global house gases (GHG), increased atmospheric $\mathrm{CO}_{2}$ gas concentration contributes to the major portion for the respective critical issue [2-4]. Industrialization and utilization of fossil fuels are considered as the prime driving factors for excessive $\mathrm{CO}_{2}$ levels. Therefore, in accordance with the adverse sentiment, it is imperative to adopt and promote an alternative technology that provides an efficient, renewable, and sustainable pathway to counterbalance excessive atmospheric $\mathrm{CO}_{2}$ level. In this regard, photocatalytic $\mathrm{CO}_{2}$ conversion (PCC) or photo-reduction to useful/value added chemicals $\left(\mathrm{CO}, \mathrm{CH}_{4}, \mathrm{C}_{2} \mathrm{H}_{6}, \mathrm{C}_{2} \mathrm{H}_{5} \mathrm{OH}, \mathrm{C}_{2} \mathrm{H}_{4}, \mathrm{CH}_{3} \mathrm{OH}\right.$, $\mathrm{HCOOH}$, etc.) is one of the most engaging and alluring approaches. PCC is based on the concept of natural photosynthesis, employing a semiconductor material acting as a photocatalyst with a 
reducing agent (e.g., $\mathrm{H}_{2} \mathrm{O} / \mathrm{H}_{2}$ etc.) for $\mathrm{CO}_{2}$ conversion to useful chemicals under the light irradiation, a free energy source [5-7]. Generally, PCC is considered as a research domain under the umbrella of artificial photosynthesis, targeting normalization of $\mathrm{CO}_{2}$ level and providing chemicals/fuels in a sustainable manner.

Since the pioneering work of Inoue et al., the photocatalysis field has been researched extensively with respect to materials [8]. As well-established, titanium dioxide $\left(\mathrm{TiO}_{2}\right)$ is counted on as one of the best photocatalytic materials due to its specific characteristics of abundant availability, high stability, better charge lifetime, favorable surface area, non-toxicity, and cost effectiveness [9]. However, despite certain benefits, $\mathrm{TiO}_{2}$ also possesses the major drawback of a limited light absorption due to its wide band gap and limited $\mathrm{CO}_{2}$ surface adsorption. Until now, enormous efforts and researches have been done to achieve an efficient photocatalytic $\mathrm{CO}_{2}$ conversion on the account of process development, such as materials with broadened light absorption, higher surface area, enhanced $\mathrm{CO}_{2}$ adsorption, and photocatalytic reactors advancement [10-14]. For the case of photocatalytic materials development, certain strategies have been executed such as doping [15,16], composite/hybrid/heterojunction formation [17-21], nano-architectures [22-24], and coupling with noble metals or carbon-based materials $[22,25,26]$. All such approaches are oriented towards attaining outstanding photocatalytic $\mathrm{CO}_{2}$ conversion efficiency.

Recently, layered double hydroxide (LDH), an interesting class of layered anionic clays, has captivated the researchers' interest for their development and application in a variety of research domains such as adsorption [27], photocatalysis [28], electrochemistry [29-32], and biomedical science [33]. Generally, LDHs are synthetically produced and rarely occur in nature. The exceptional properties of $\mathrm{LDH}$, i.e., their superb adsorption capacity extended light absorption via compositional variation, cheap synthesis procedure, and unique layered morphology, making them suitable materials for photocatalysis applications [28]. Until now, a moderate number of researches and studies have been reported employing LDH regarding their synthesis approaches and electronic and physical properties influencing photocatalytic applications [32,34]. However, specific to PCC, there exist limited reports employing bare LDH, surface modified LDH, or hybrid LDH based photocatalysts.

In the present review, the recent progress of bare LDH and LDH based photocatalysts employed for photocatalytic $\mathrm{CO}_{2}$ conversion to useful chemicals/fuels are briefly overviewed. The synthesis procedure involved, key reaction conditions, PCC mechanism, and prime parameters promoting the improvement of photocatalytic performance are detailed. In short, the review is a brief overview of LDH based photocatalysts offering excellent performance for PCC.

\section{Layered Double Hydroxide (LDH) Structure and Synthesis}

LDH are mainly synthetic materials with their structure mimicking natural mineral hydrotalcite $\left(\mathrm{Mg}_{6} \mathrm{Al}_{2}(\mathrm{OH})_{16}\right) \mathrm{CO}_{3} . \mathrm{H}_{2} \mathrm{O}$ was discovered in 1842 and synthetically prepared in 1942 [35]. The detailed structural investigation of the LDH was conducted by Allmann and co-authors in 1969 [36]. Hence, LDH are composed of layered structure and are also termed hydrotalcite-like compounds comprising brucite like metal hydroxide layers and water molecules balanced by interlayer anions. The commonly accepted formula representing the $\mathrm{LDH}$ is $\left[\mathrm{M}_{1-x}^{2+} M_{x}^{3+}(\mathrm{OH})_{2}^{A ?}\right] A^{x+}\left[A^{n-}\right]_{x / n} \cdot \mathrm{mH}_{2} \mathrm{O}$, where $\mathrm{M}^{2+}\left(\right.$ e.g., $\mathrm{Mg}^{2+}, \mathrm{Cu}^{2+}$, $\mathrm{Ni}^{2+}, \mathrm{Zn}^{2+}$ etc.) and $\mathrm{M}^{3+}$ (e.g., $\mathrm{Al}^{3+}, \mathrm{Fe}^{3+}, \mathrm{Ga}^{3+}$ etc.) represents the divalent and trivalent cations, respectively. $\mathrm{A}^{\mathrm{n}-}$ indicates the interlayer gallery ions such as $\mathrm{CO}_{3}{ }^{2-}, \mathrm{NO}_{3}{ }^{2-}, \mathrm{Cl}^{-}$, etc. along with water molecules. The illustration of commonly acknowledged and endorsed LDH is shown in Figure 1.

It is well established that the composition of the LDH, their structure, and certain properties can be controlled and manipulated by the nature of the synthesis procedure. Primarily the synthesis procedure can be classified based on the phase involved, i.e., (1) solid phase and (2) liquid phase synthesis approach. Solid state synthesis approach mainly consists of mechanochemical process employing wet and dry milling methods $[37,38]$. Such approach offers benefit of less pollution in terms of liquids used but again is an expensive method, with a major drawback of structure distortion and nonuniform LDH structure. On the contrary, liquid phase synthesis approach is a commonly adopted 
and dominant strategy because of its easiness, cost effectiveness, and provision of the prime benefits of complete and uniform LDH structural morphology. The liquid phase synthesis approach is further branched into variety of synthesis methods based on the reaction type [39-41]. Some of important and commonly practiced liquid phase synthesis methods can be listed as follows:

I. Co-precipitation method;

II. Anion exchange method;

III. Reconstruction/rehydration method;

IV. Solution mixing method.

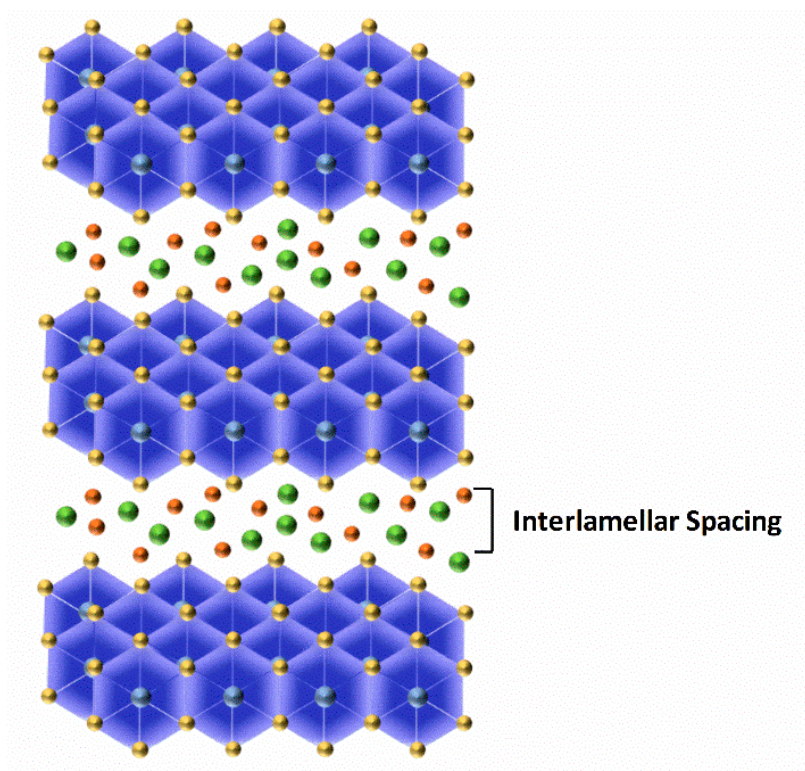

\section{- Anion $\left(\mathrm{A}^{\mathrm{n}-}\right) \cdot \mathrm{H}_{2} \mathrm{O} \rightarrow$ Metal $\left(\mathrm{M}^{2+} / \mathrm{M}^{3+}\right)$}

Figure 1. Structural illustration of layered double hydroxide (LDH).

Amongst the above-mentioned methods, co-precipitation method is the most frequently adopted synthesis approach offering a direct method for the synthesis of LDH. Co-precipitation method practices slow addition of anionic solution to the divalent or trivalent metal cations solution, with addition of alkali or urea, resulting in hydrolysis and finally precipitation of LDH. The addition of base or urea in metal cations solution leads to co-precipitation of metallic salts via condensation of hexa-aqua metal complexes finally resulting in brucite-like metal cations layers with solvated interlamellar anions.

Anion exchange method employs the exchange of the intercalated anions by other targeted anions. In this method, already prepared LDH is subjected to stirring in the targeted anions solution, which are to be intercalated to achieve the required LDH. Moreover, when the co-precipitation method is not feasible, anion exchange method is utilized, e.g., when either metal cations or anions are unstable in alkaline solution or when there is chance of direct reaction between the cations and intercalated anions. Under these specific circumstances, anion exchange method offers viable alternative approach to synthesize the desired LDH by exchanging the intercalated anions with the target anions.

Another interesting synthesis method is the reconstruction method. Like shape memory materials, LDH materials also tend to return to their original structure. Generally, when the LDH materials are calcined at higher temperatures $\left(400-500{ }^{\circ} \mathrm{C}\right)$, the intercalated anions and water molecules are completely erased, and hydroxides are converted to respective metal oxides. These metal oxides are immersed in water or targeted anion solution, and the metal hydroxide and intercalated layers of anions are regenerated, and LDH is reformed. Such process is very fruitful for intercalating the specific targeted anions in the interlayer gallery of the LDH. 
Simple solution mixing and then subjecting it to high temperature and pressure conditions such as hydrothermal or solvothermal approaches are another effective mean to fabricate the LDH and/or LDH based composites with other semiconductor materials.

In addition to the abovementioned methods, i.e., hydrothermal [42], there exist a variety of synthesis methods such as sol-gel [43], and microemulsion methods [44], which can be adopted based on the required features and properties of the $\mathrm{LDH}$.

\section{Bare and Modified Layered Double Hydroxide (LDH) Photocatalysts}

Layered double hydroxide (LDH) is mainly comprised of layered morphology, providing important aspects of (i) broader light absorption (generally in the visible light range) and (ii) better $\mathrm{CO}_{2}$ sorption capability because of their layered morphology. Moreover, the choice of metal cations within LDH can well tune the photocatalytic activity by influencing its light absorption and sorption attributes. Ahmed et al. [45] studied the effect of the metal cation for zinc-copper-M (III) LDH, where M stands for aluminum ( $\mathrm{Al}$ ) or gallium $(\mathrm{Ga})$ metal. It was observed that samples composed of ternary metal ions, i.e., $\mathrm{ZnCuAl}$ and $\mathrm{ZnCuGa} \mathrm{LDH,} \mathrm{show} \mathrm{a} \mathrm{red} \mathrm{shift} \mathrm{in} \mathrm{their} \mathrm{light} \mathrm{absorption} \mathrm{as} \mathrm{compared} \mathrm{to} \mathrm{ZnAl}$ and $\mathrm{ZnGa}$ LDHs. Hence, the insertion of $\mathrm{Cu}$ in both mentioned LDHs extends their absorption towards the visible range, which might be due to the generation of an electronic state induced by $\mathrm{Cu}$ ions, thus narrowing down the band gap. Under the UV-Vis photo irradiation and reactant mixture consisting of $\mathrm{CO}_{2}$ and $\mathrm{H}_{2}$, the $\mathrm{ZnCuAl}$ and $\mathrm{ZnCuGa} \mathrm{LDH}$ produced mainly $\mathrm{CH}_{3} \mathrm{OH}$ as a key product component as compared to $\mathrm{ZnAl}$ and $\mathrm{ZnGa} \mathrm{LDHs}$, which mainly yielded $\mathrm{CO}$ as a key product. Hence, the selectivity of the product mainly from $\mathrm{CO}$ switches to $\mathrm{CH}_{3} \mathrm{OH}$ with the incorporation of the $\mathrm{Cu}$ in the $\mathrm{LDH}$. The role of $\mathrm{Cu}$ addition is responsible for increased production of $\mathrm{CH}_{3} \mathrm{OH}$ as compared to $\mathrm{CO}$. $\mathrm{Cu}$ sites within the $\mathrm{LDH}$ might be providing a binding site for $\mathrm{CO}_{2}$, thus interacting with photogenerated electrons, protons, and probably the $\mathrm{Cu}^{\mathrm{I}} / \mathrm{Cu}^{\mathrm{II}}$ redox couple. The proposed mechanism is shown in Figure 2a, where the interlayer hydroxl group linked with $\mathrm{Ga} / \mathrm{Al}$ and $\mathrm{Cu}$ ties with the $\mathrm{CO}_{2}$ molecule resulting in hydrogen carbonate, which undergoes a series of reduction reactions in presence of protons finally forming the $\mathrm{CH}_{3} \mathrm{OH}$ as a major product. Furthermore, the insertion of $\mathrm{Cu}$ narrows down the band gap and well, aligning it with the redox level of $\mathrm{CO}_{2} / \mathrm{CH}_{3} \mathrm{OH}$ as shown by energy level diagram in Figure $2 \mathrm{~b}$. Such a band gap alignment is favorable for producing $\mathrm{CH}_{3} \mathrm{OH}$ under light irradiation.

As investigated in their previous research [45], the interlayer space within LDH layers acts as an active site for the $\mathrm{CO}_{2}$ conversion to $\mathrm{CH}_{3} \mathrm{OH}$ with higher selectivity when $\mathrm{Cu}$ is inserted. Hence, extending their investigation with the modification of the interlayer space of the LDH for enhancing the photocatalytic performance via anionic species between the cationic LDH layers, Ahmed and co-authors [46] found an increased $\mathrm{CH}_{3} \mathrm{OH}$ formation rate. They found, during the synthesis process of $\mathrm{Zn}_{3} \mathrm{Ga} \mid \mathrm{CO}_{3}$ and $\mathrm{Zn}_{1.5} \mathrm{Cu}_{1.5} \mathrm{Ga} \mid \mathrm{CO}_{3} \mathrm{LDH}$, the $\left(\mathrm{CO}_{3}\right)^{2-}$ is replaced with $\left[\mathrm{Cu}(\mathrm{OH})_{4}\right]^{2-}$ anions by $\left[\mathrm{CuCl}_{4}\right]^{2-}$ ions hydrolyzed in the alkaline solution. It was observed with the intercalation of the $\left[\mathrm{Cu}(\mathrm{OH})_{4}\right]^{2-}$ anions that the light absorption is shifted towards the lower energy as compared to samples with $\left(\mathrm{CO}_{3}\right)^{2-}$ anions. Moreover, $\mathrm{Cu}$ insertion also exhibits the absorption in the visible range due to intrinsic property of $\mathrm{Cu}$ ions. The $\mathrm{Zn}_{3} \mathrm{Ga} \mid \mathrm{Cu}(\mathrm{OH})_{4} \mathrm{LDH}$ photocatalyst exhibits 5.9 times higher $\mathrm{CH}_{3} \mathrm{OH}$ production as compared to $\mathrm{Zn}_{3} \mathrm{Ga} \mid \mathrm{CO}_{3}$ and similar to that of $\mathrm{Zn}_{1.5} \mathrm{Cu}_{1.5} \mathrm{Ga} \mid \mathrm{CO}_{3}$. However, $\mathrm{Zn}_{1.5} \mathrm{Cu}_{1.5} \mathrm{Ga} \mid \mathrm{Cu}(\mathrm{OH})_{4}$ shows an increase selectivity of $\mathrm{CH}_{3} \mathrm{OH}$ up to $88 \%$. The investigation concludes that the modification of the respective LDH photocatalysts with the $\mathrm{Cu}(\mathrm{OH})_{4}$ anions instead of $\mathrm{CO}_{3}$ anions leads to increase of interlayer space between the LDH thus resulting in more reactive space. Secondly, the insertion of the $\mathrm{Cu}$ ions narrows the bandgap of the resulting LDH photocatalyst with more light absorption and thus better photocatalytic performance.

Another report investigates the role of the precursor anions for hydroxide sheets, for various LDH photocatalysts including Ni-Al, Zn-Al, Mg-In, and Ni-In [47]. The LDH were synthesized by both nitrates $\left(\mathrm{LDH}-\mathrm{NO}_{3}{ }^{-}\right)$and chlorides $\left(\mathrm{LDH}-\mathrm{Cl}^{-}\right)$and evaluated for their photocatalytic activity in terms of $\mathrm{CO}_{2}$ conversion to useful chemicals. It was observed that the $\mathrm{LDH}$ with Ni/Al ratio of 4 
and synthesized using chlorides exhibited the maximum $\mathrm{CO}_{2}$ conversion to $\mathrm{CO}$. It was noticed that except Ni-Al LDH-Cl- all other samples selectively generate $\mathrm{H}_{2}$; however, $\mathrm{Ni}-\mathrm{Al} \mathrm{LDH}-\mathrm{Cl}^{-}$mainly yielded $\mathrm{CO}$ from $\mathrm{CO}_{2}$ photo-reduction. The production rate of various products obtained from variety of LDH photocatalysts can be seen in Figure 3a. The reason for the selective formation of $\mathrm{CO}$ for $\mathrm{Ni}-\mathrm{Al} \mathrm{LDH}-\mathrm{Cl}^{-}$can be attributed to the co-catalytic behavior of the Ni species, which in turn leads to the enhancement of $\mathrm{CO}$ formation as the Ni ratio is increased. For the other LDH photocatalysts, $\mathrm{H}_{2}$ is mainly produced due to competition of $\mathrm{H}^{+}$being reduced during the $\mathrm{CO}_{2}$ photo-reduction, a well-known competitive reaction phenomenon. Furthermore, when the Ni content is decreased within $\mathrm{Ni}-\mathrm{Al} \mathrm{LDH}-\mathrm{Cl}^{-}$, the $\mathrm{CO}$ formation is decreased, and $\mathrm{H}_{2}$ formation is increased, which endorses $\mathrm{Ni}$ species to act as a co-catalyst during the $\mathrm{CO}_{2}$ photo-reduction reaction. The Ni-Al $\mathrm{LDH}-\mathrm{NO}_{3}{ }^{-}$, on the contrary, showed the production of $\mathrm{CH}_{4}$ when employed for $\mathrm{CO}_{2}$ photo-reduction. The authors also found that $\mathrm{Cl}^{-}$ions in the aqueous solution also act as hole scavengers, thus promoting the selective formation of $\mathrm{CO}$ instead of other products.

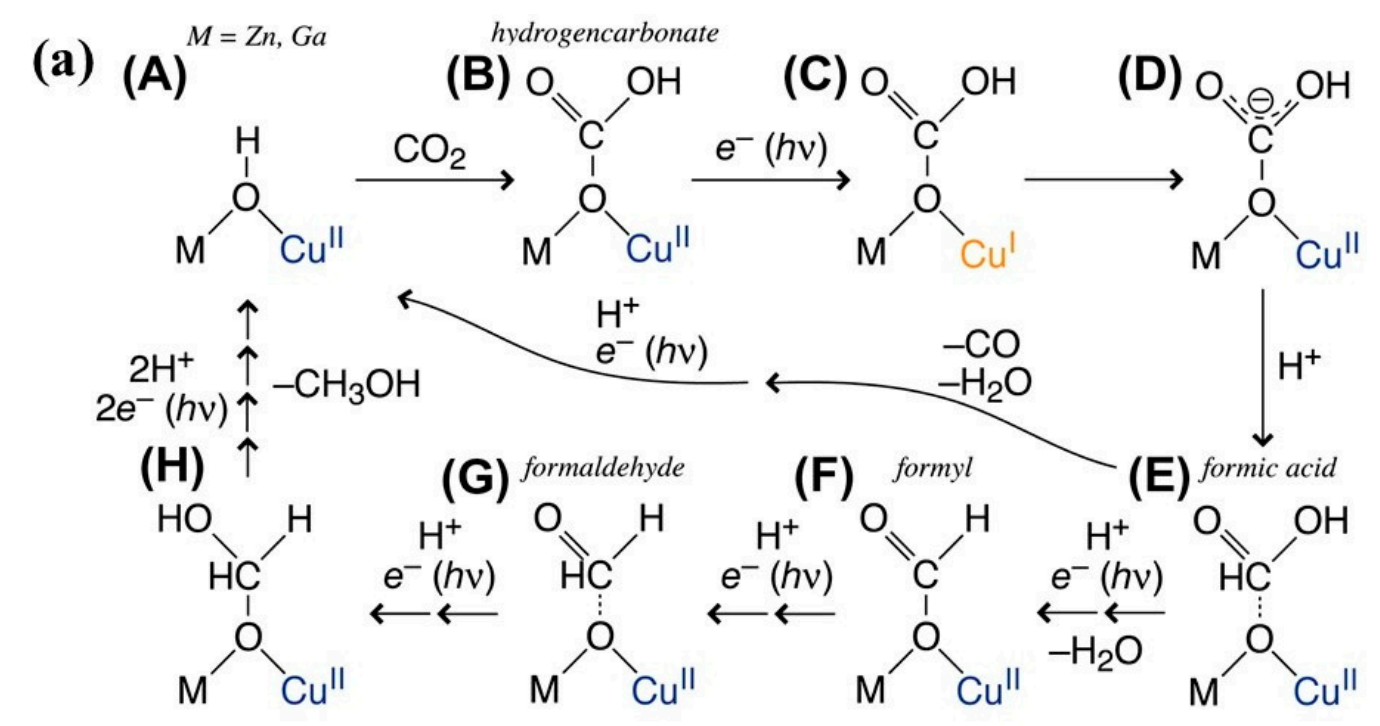

(b)

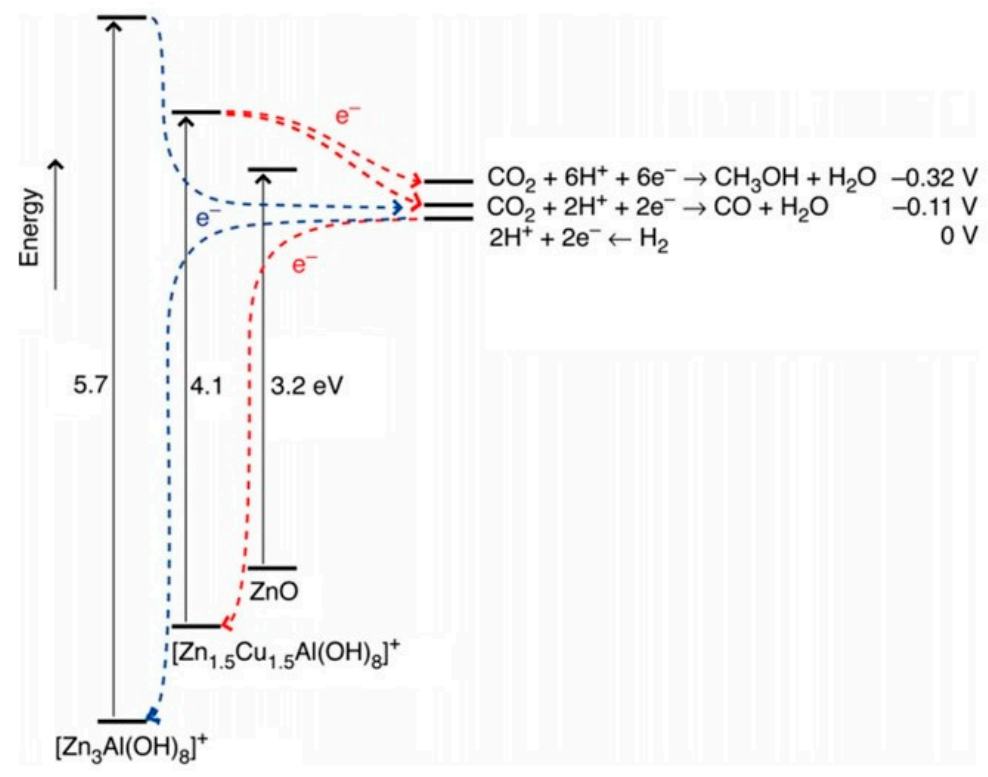

Figure 2. (a) Photocatalytic reactions proposed for the $\mathrm{CO}_{2}$ photo-reduction to $\mathrm{CH}_{3} \mathrm{OH}$ employing $\mathrm{ZnCuGa} \mathrm{LDH}$. (b) Band gap alignment of $\mathrm{ZnCuAl} \mathrm{LDH}$ (with varied $\mathrm{Zn}, \mathrm{Cu}$ and $\mathrm{Al}$ ratio) against the redox potential of $\mathrm{CH}_{3} \mathrm{OH}, \mathrm{CO}$ and $\mathrm{H}_{2}$. (taken with permission from reference [45]. Copyright 2011, Elsevier). 
(a)

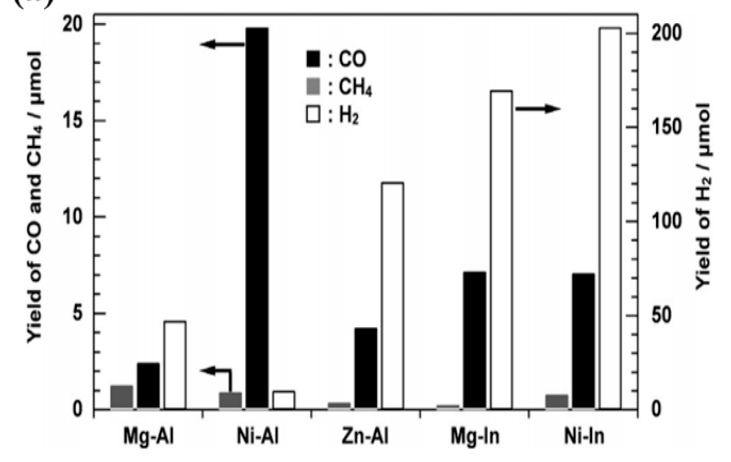

(b)

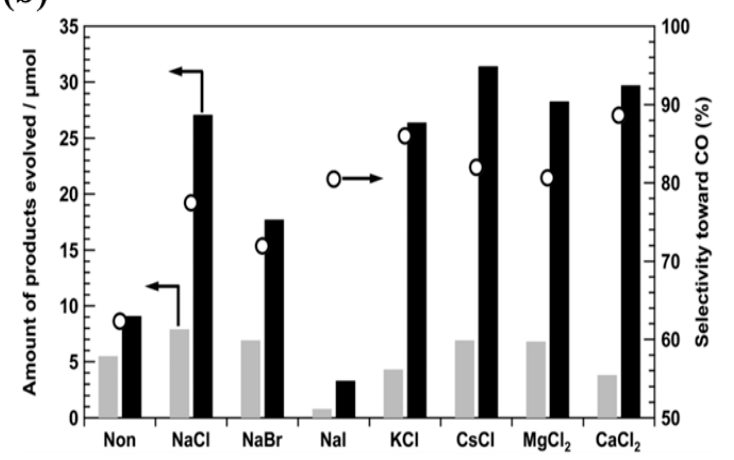

Figure 3. (a) Photocatalytic $\mathrm{CO}_{2}$ conversion to useful chemicals over various $\mathrm{M}-\mathrm{Al}$ or $\mathrm{M}-\mathrm{In} \mathrm{LDH}$, where $\mathrm{M}$ stands for $\mathrm{Mg}$, Ni, $\mathrm{Zn}$. (b) Photocatalytic CO evolution rate and its selectivity for Ni-Al LDH with various salt additives (Figures taken with permission from reference [47] copyright 2011, Elsevier and [48] copyright 2015, The royal society of chemistry).

Continuing the role of $\mathrm{Cl}^{-}$ions, Iguchi et al. researched the effect of $\mathrm{Cl}^{-}$ions as a hole scavenger in $\mathrm{CO}_{2}$ photo-reduction employing $\mathrm{Ni}-\mathrm{Al} \mathrm{LDH} \mathrm{[48].} \mathrm{Various} \mathrm{additives} \mathrm{were} \mathrm{added} \mathrm{in} \mathrm{the} \mathrm{aqueous}$ solution containing suspended LDH photocatalyst, bubbled with $\mathrm{CO}_{2}$ gas, and irradiated using $400 \mathrm{~W}$ high pressure mercury lamp. The additives were $\mathrm{NaHCO}_{3}, \mathrm{Na}_{2} \mathrm{CO}_{3}, \mathrm{Na}_{2} \mathrm{SO}_{4}, \mathrm{NaNO}_{3}$, and $\mathrm{NaCl}$. It was observed that $\mathrm{NaHCO}_{3}$ and $\mathrm{Na}_{2} \mathrm{CO}_{3}$ exhibited a greater selectivity towards $\mathrm{H}_{2}$ generation due to favorable reduction of $\mathrm{H}^{+}$ions generated in water. $\mathrm{The} \mathrm{Na}_{2} \mathrm{SO}_{4}$ and $\mathrm{NaNO}_{3}$ did not contribute in the formation of either product, $\mathrm{H}_{2}$ or $\mathrm{CO}$. However, when $\mathrm{NaCl}$ was used as an additive, a significant amount of $\mathrm{CO}$ was produced with higher selectivity as compared to all other additives. The selectivity along with production rate of $\mathrm{H}_{2}$ and $\mathrm{CO}$ with various inorganic additives can be viewed in Figure $3 \mathrm{~b}$ (dark bar represents $\mathrm{CO}$, grey bar $\mathrm{H}_{2}$ and circle represents selectivity towards $\mathrm{CO}$ formation). In order to understand the mechanism involved, DPD $(\mathrm{N}, \mathrm{N}$-dimethyl-p-phenylenediamine) test was performed. The DPD test indicated that when the $\mathrm{NaCl}$ was added to aqueous solution, the product was consisted of $\mathrm{CO}, \mathrm{H}_{2}$ and $\mathrm{HClO}$ under photoirradiation as a reaction amongst $\mathrm{CO}_{2}, \mathrm{H}^{+}$and $\mathrm{Cl}^{-}$. Hence, the formation of $\mathrm{HClO}$ as an oxidant product during the photoreaction indicates that $\mathrm{Cl}^{-}$is expected to be a strong reducing agent and is rapidly oxidized by holes in the solution leading to yield $\mathrm{HClO}$ and selective formation of $\mathrm{CO}$.

Another report investigated the role of fluorinated surface of LDH photocatalysts and their role in the $\mathrm{CO}_{2}$ conversion enhancement [49]. The authors fabricated fluorinated $\mathrm{Mg}-\mathrm{Al}$ and $\mathrm{Ni}-\mathrm{Al} \mathrm{LDH}$ photocatalysts and evaluated their photocatalytic performance for the $\mathrm{CO}_{2}$ conversions in aqueous solution. The fluorination was done by incorporating hexafluoroaluminate $\left(\mathrm{AlF}_{6}{ }^{3-}\right)$ units within the hydroxide sheets of the LDH. In addition, various samples of LDH were prepared by changing the concentration of fluorine precursor, with the optimized sample providing the maximum yield of $\mathrm{CO}$ as a main product of $\mathrm{CO}_{2}$ photo-reduction. It was observed and confirmed in authors previous works that the $\mathrm{Ni}-\mathrm{Al} \mathrm{LDH}$ is more efficient in selective formation of $\mathrm{CO}$ as compared to $\mathrm{Mg}$ - $\mathrm{Al} \mathrm{LDH}$ as Ni species are supposed to act as co-catalyst, thus suppressing the formation of $\mathrm{H}_{2}$. However, the optimized fluorine content (which was estimated by ratio of fluorine precursor to the aluminum precursor of LDH and was found 7.5) significantly enhances the formation of $\mathrm{CO}$ with $\mathrm{NaCl}$ as an additive for the hole scavenger. Such an improvement is mainly associated with the increased surface area of the fluorinated $\mathrm{LDH}$, which leads to higher sites for $\mathrm{CO}_{2}$ adsorption and thus increased $\mathrm{CO}_{2}$ photo-reduction to $\mathrm{CO}$.

The work done by Flores et al. investigates the role of various $\mathrm{Mg}$ sources, organic precursor and a one-step microwave-hydrothermal method on the photocatalytic activity of Mg-Al LDH [50]. Two different salts of magnesium, i.e., magnesium acetate and magnesium nitrate, were used with organic urea as a source of $\mathrm{CO}_{3}{ }^{-}$and $\mathrm{OH}^{-}$within $\mathrm{LDH}$ layers. The $\mathrm{LDH}$ photocatalysts were then subjected for two different times for microwave radiation for 20 and $40 \mathrm{~min}$ and at a temperature of $100{ }^{\circ} \mathrm{C}$. All the samples were employed for photocatalytic $\mathrm{CO}_{2}$ conversion in gas as well as liquid 
phase reactions. It was observed that the crystallinity of the synthesized LDH was significantly influenced by the nature of the $\mathrm{Mg}$ precursor and microwave irradiation time. The greater microwave irradiation time leads to formation of a larger crystallite size along with decomposition of organic urea resulting in formation of $\mathrm{NH}_{4}{ }^{+}, \mathrm{OH}^{-}, \mathrm{H}^{+}$, and $\mathrm{CO}_{3}{ }^{2-}$ ions, which will readily react with $\mathrm{Mg}^{2+}$ due to higher dipole moment, thus resulting in better crystallinity. When the prepared LDH photocatalysts were employed in liquid phase for $\mathrm{CO}_{2}$ conversion, the key product formed was $\mathrm{CH}_{3} \mathrm{OH}$ with the highest yield obtained from $\mathrm{Mg}-\mathrm{Al} \mathrm{LDH}$ prepared by respective acetate salt under 40 min microwave radiation. Hence, by increasing the microwave irradiation time, the crystallite size and crystallinity are improved, which leads to decreased impedance, whereas, the decomposition of acetate anions adsorbed on LDH surface in turn facilitated the electron transfer towards the $\mathrm{CO}_{2}$ sites within LDH. Such decomposition for $\mathrm{LDH}$ obtained by nitrates salts resulted in formation of $\mathrm{NO}_{3}{ }^{-}$, which can occupy the $\mathrm{CO}_{2}$ active site. Figure 4 a displays the $\mathrm{CH}_{3} \mathrm{OH}$ production by various $\mathrm{LDH}$ photocatalysts prepared in the reported work. When the optimized LDH photocatalysts were employed for gas phase reactions, the key products obtained were $\mathrm{CO}$ and $\mathrm{CH}_{4}$. Such formation of $\mathrm{CO}$ and $\mathrm{CH}_{4}$ under gas phase is more favorable due to its potential lowering than the $\mathrm{CH}_{3} \mathrm{OH}$ formation and deoxygenation of C-species with electrons. The band gap alignment of all the $\mathrm{Mg}-\mathrm{Al} \mathrm{LDH}$ prepared in the respective work is shown in Figure 4b.
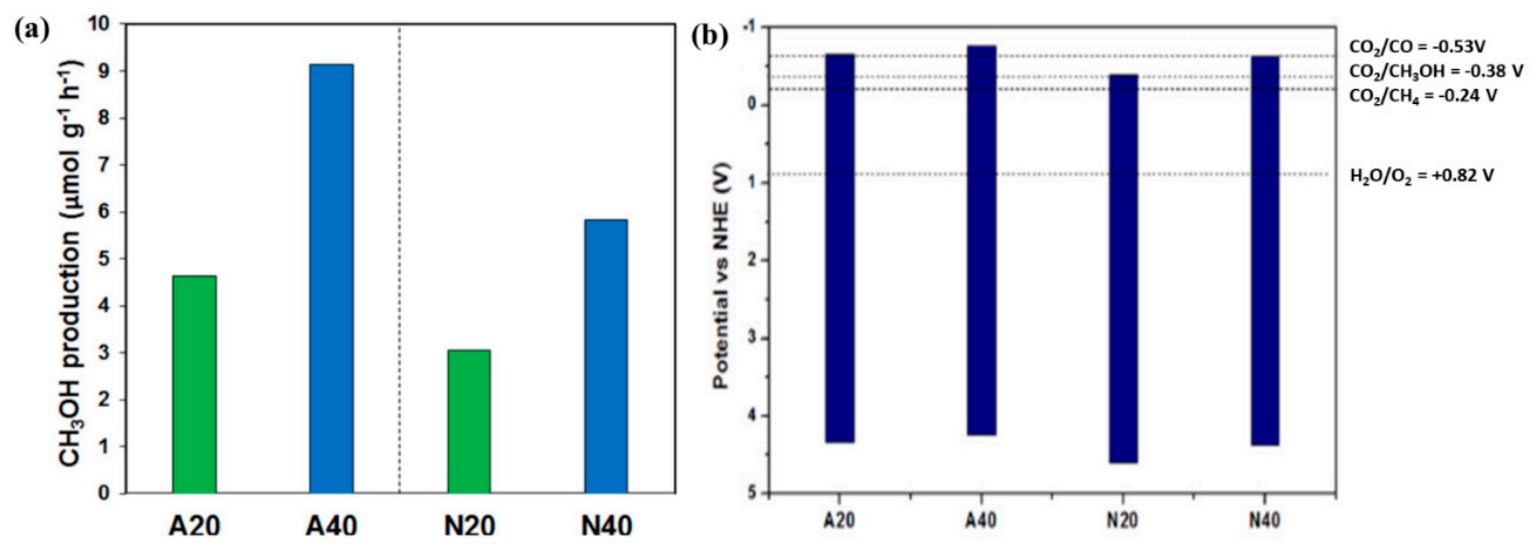

Figure 4. (a) Photocatalytic $\mathrm{CO}_{2}$ conversion to $\mathrm{CH}_{3} \mathrm{OH}$ for $\mathrm{Mg}-\mathrm{Al} \mathrm{LDH}$ photocatalyst; A represents acetate precursor, and $\mathrm{N}$ stands for nitrate precursor; 20 and 40 stands for microwave radiation time in minutes. (b) Band gap alignment of respective $\mathrm{Mg}-\mathrm{Al} \mathrm{LDH}$ against the redox potential of $\mathrm{CH}_{3} \mathrm{OH}, \mathrm{CO}$, $\mathrm{CH}_{4}$, and $\mathrm{H}_{2} \mathrm{O}$. (Figures taken with permission from reference [50] Copyright 2018, Elsevier)).

A recent work done by Wang et al. presents synthesis of $\mathrm{Co}-\mathrm{Al} \mathrm{LDH}$ nanosheets for the conversion of very low concentration atmospheric $\mathrm{CO}_{2}$ and water to $\mathrm{CH}_{4}$ [51]. Furthermore, the investigation also focuses on the importance of alkaline $\mathrm{OH}$ group and divalent cobalt for efficient $\mathrm{CO}_{2}$ conversion to $\mathrm{CH}_{4}$. Figure $5 \mathrm{a}$,b show the morphology of the prepared Co-Al LDH nanosheets, showing hexagonal sheet like morphology and thickness of $18 \mathrm{~nm}$. The unique attribute was the uniform composition of $\mathrm{Co}, \mathrm{Al}$, and $\mathrm{O}$ elements. The UV-Vis absorption spectrum for the Co-Al LDH nanosheets suggests the light absorption of the synthesized photocatalyst lies in the visible range with an estimated band gap of $2.1 \mathrm{eV}$. Thus, the respective photocatalyst can capture the visible range of the light, which can probably lead to improve photocatalytic performance. The synthesized Co-Al LDH nanosheets were found to be active for $55 \mathrm{~h}$ of irradiation with atmospheric $\mathrm{CO}_{2}\left(400 \mathrm{ppm}\right.$ ), yielding $\mathrm{CH}_{4}$ as a main product with rate of $4.3 \mu \mathrm{mol} \mathrm{g}-1 \mathrm{~h}^{-1}$, which is 13 times higher as compared to standard $\mathrm{TiO}_{2}$ sample, i.e., P25. The improved $\mathrm{CH}_{4}$ generation was mainly attributed to the enhanced $\mathrm{CO}_{2}$ adsorption by surface $\mathrm{OH}$ groups and unique effect of divalent cobalt. The divalent characteristic of cobalt was investigated by oxidation of the $\mathrm{Co}-\mathrm{Al} \mathrm{LDH}$ in oxygen atmosphere, and it was observed that the photocatalytic performance was sharply decreased when the LDH was oxidized. Moreover, the LDH photocatalyst exhibited a stable photocatalytic performance over five cycles of repeated reaction as 
shown in Figure 5c. The mechanistic view displaying the proposed reduction mechanism for $\mathrm{CO}_{2}$ conversion upon the surface of Co-Al LDH is shown in Figure $5 \mathrm{~d}$. The $\mathrm{CO}_{2}$ reduction is proposed to initiate with the chemisorption of $\mathrm{CO}_{2}$ and $\mathrm{OH}$ groups, which can bend linear $\mathrm{CO}_{2}$ molecule, thus activating them to form carbonate species. These carbonate species in the presence of electrons and protons undergo multistep proton assisted reaction forming $\mathrm{CO}$, which is finally converted to $\mathrm{CH}_{4}$ and other useful chemicals.
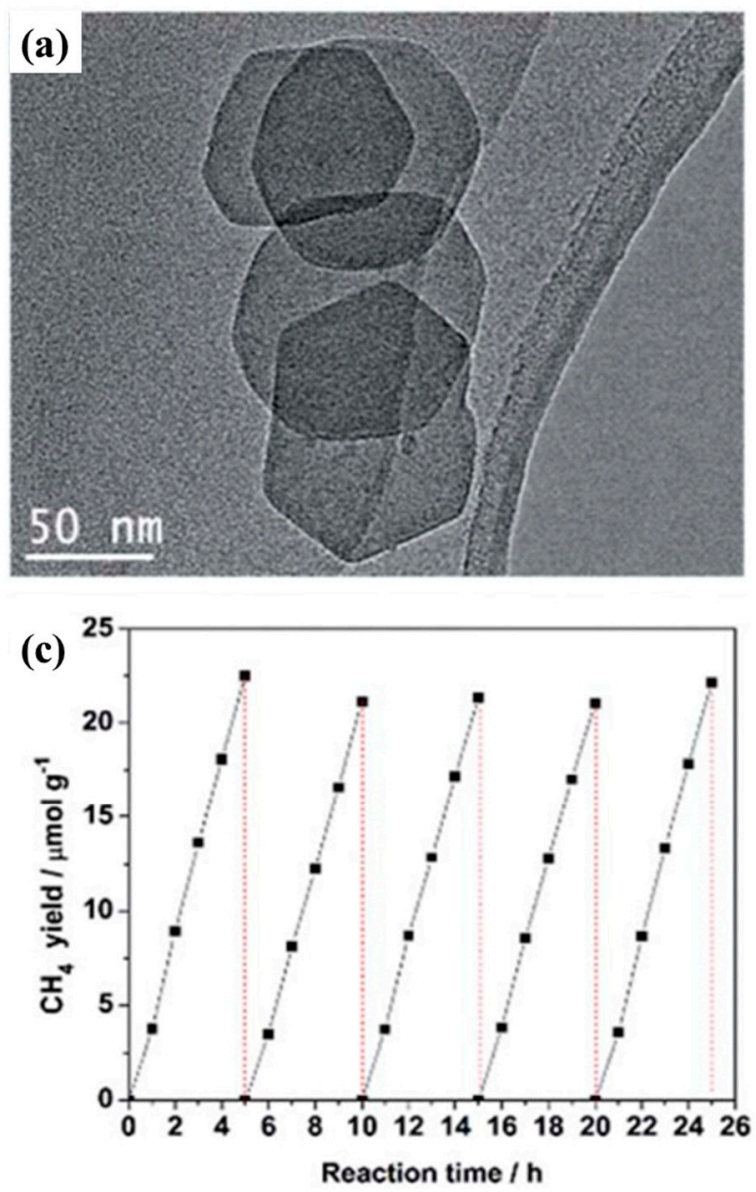

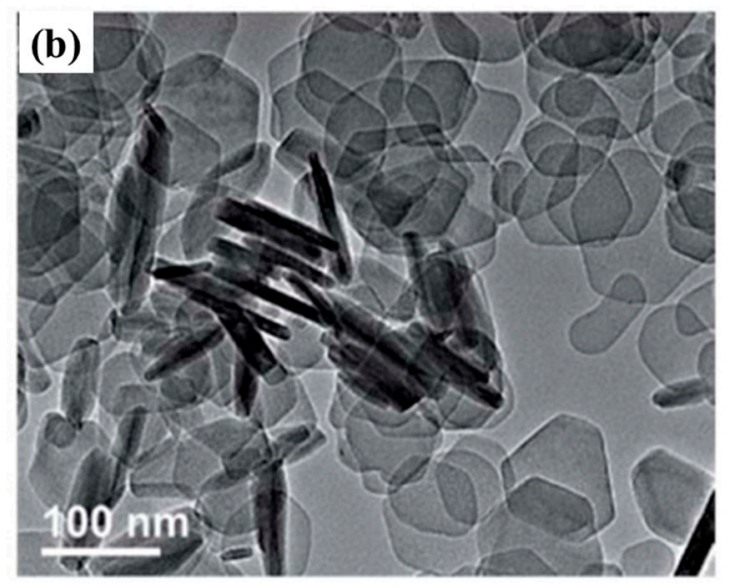

(d)

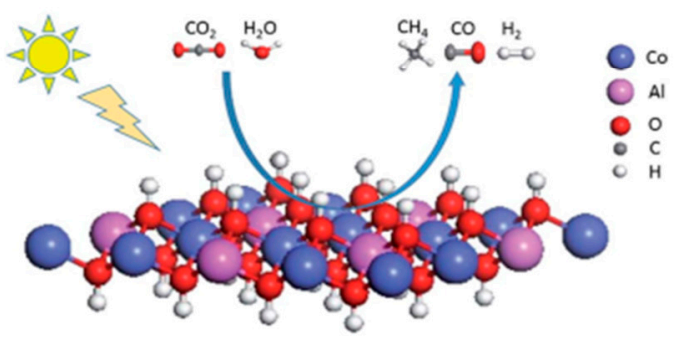

Figure 5. (a,b) TEM images of the Co-Al LDH Nanosheets displaying a hexagonal type morphology. (c) Photocatalytic $\mathrm{CO}_{2}$ conversion to $\mathrm{CH}_{4}$ for $\mathrm{Co}-\mathrm{Al} \mathrm{LDH}$ photocatalyst over more than 5 cycles of evaluation. (d) Mechanistic view of the photocatalytic process occurring at the surface of the Co-Al LDH.

(Figures taken with permission from reference [51]. Copyright 2018, The Royal Society of Chemistry).

In another work, Tokudome et al. reported synthesis of nanocrystalline Ni-Al LDH ( $20 \mathrm{~nm})$ by simple homogenous supersaturation process induced via rapid increase of $\mathrm{pH}$ form concentrated aqueous salt solutions of precursors [52]. When $\mathrm{Ni}-\mathrm{Al} \mathrm{LDH}$ was employed for $\mathrm{CO}_{2}$ conversion in aqueous medium, the $\mathrm{CO}$ formation rate (selectivity of $80 \%$ ) was found 7 times higher as compared to the standard Ni-Al LDH prepared by conventional method. The key for the improved photocatalytic performance was attributed to the metastable surface of the nano LDH due to high degree of supersaturation. Figure 6a shows the morphology of the nano LDH and standard LDH. Nano LDH mainly consists of $20 \mathrm{~nm}$ particle size in agglomerated form whereas the conventional LDH is mainly composed of various size ranges of platelets within a range of $40-200 \mathrm{~nm}$. Figure $6 \mathrm{~b}$ shows the photocatalytic $\mathrm{CO}_{2}$ conversion to $\mathrm{CO}$ in aqueous media. It was observed that nano LDH exhibited a significant increase in $\mathrm{CO}$ production as compared to standard LDH. This was mainly attributed to the surface affinity of the nano $\mathrm{LDH}$ towards the $\mathrm{CO}_{2}$ adsorption in gaseous phase. Such a specific surface nature is induced mainly due to synthesis process designed in the research work. Furthermore, for the 
purpose of comparison, various control samples were synthesized in order to investigate the role of morphology and crystallinity of nano $\mathrm{LDH}$ for $\mathrm{CO}_{2}$ conversion. However, it was observed that all those parameters, when improved, exhibited a decrease in photocatalytic performance; hence ultimately, the metastable surface of the nano $\mathrm{LDH}$ and its superb affinity towards $\mathrm{CO}_{2}$ adsorption can only be considered as the key to success of improved photocatalytic performance.

(a)

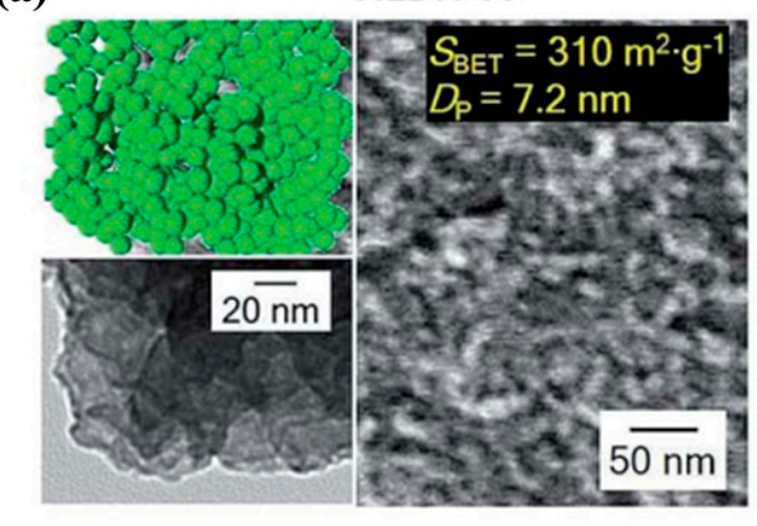

NLDH-05

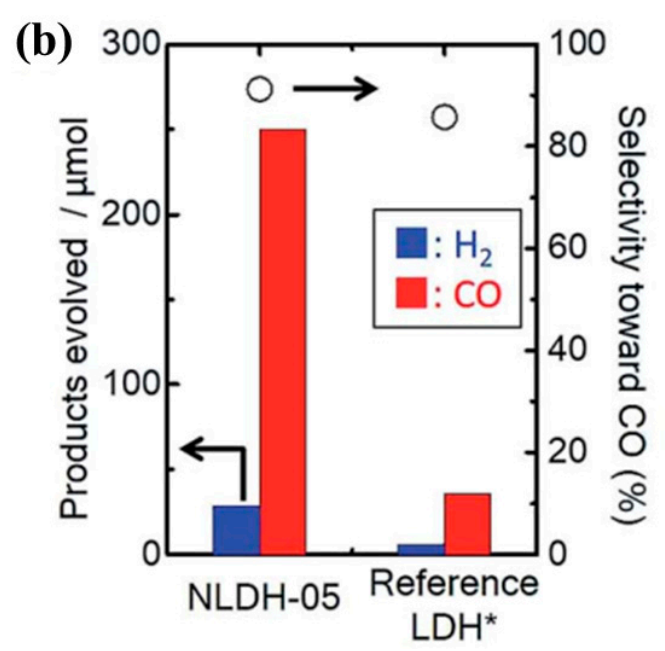

Figure 6. (a) Surface morphology of the nano Ni-Al LDH and bulk Ni-Al LDH with its surface area and particle size. (b) Photocatalytic $\mathrm{CO}_{2}$ conversion to $\mathrm{CO}$ and $\mathrm{H}_{2}$ for nano Ni-Al LDH (NLDH) and bulk Ni-Al LDH (reference LDH) with respective selectivity (Figures taken with permission from reference [52]. Copyrights 2018, The Royal Society of Chemistry).

A recently published research work by Gao et al. presented an ultrathin Mg-Al LDH modified with $\mathrm{Fe}_{3} \mathrm{O}_{4}$ by a simple coprecipitation approach [53]. It was observed that $\mathrm{Fe}_{3} \mathrm{O}_{4} / \mathrm{Mg}-\mathrm{Al} \mathrm{LDH}$ (FMAL) exhibited significant improvement in the photocatalytic activity, which was due to synergetic effect of efficient separation of electron-hole pairs and reduction of resistance for charges transmission induced by $\mathrm{Fe}_{3} \mathrm{O}_{4}$ and ultrathin $\mathrm{Mg}-\mathrm{Al} \mathrm{LDH}$, respectively. Figure 7a shows the transmission electron microscopy (TEM) image of $\mathrm{Fe}_{3} \mathrm{O}_{4} / \mathrm{Mg}-\mathrm{Al} \mathrm{LDH}$, which exhibits thin 2D nanosheets of $\mathrm{Mg}-\mathrm{Al} \mathrm{LDH}$ with $\mathrm{Fe}_{3} \mathrm{O}_{4}$ nanoparticles loaded on nanosheets. The UV-Vis DRS for the $\mathrm{Fe}_{3} \mathrm{O}_{4} / \mathrm{Mg}-\mathrm{Al} \mathrm{LDH}$ is shown in Figure $7 \mathrm{~b}$. The light absorption spectrum covers visible region due to presence of $\mathrm{Fe}_{3} \mathrm{O}_{4}$ nanoparticles, which possess a narrow band gap and almost act like a conductor. Such conductive behavior leads to inhibition of photogenerated electron-hole recombination, thus contributing to improved photocatalytic performance. Figure $7 \mathrm{c}$,d show the photocatalytic production of $\mathrm{CO}$ and $\mathrm{CH}_{4}$ by various $\mathrm{Fe}_{3} \mathrm{O}_{4} / \mathrm{Mg}-\mathrm{Al} \mathrm{LDH}$ samples (with varied content of $\mathrm{Fe}_{3} \mathrm{O}_{4}$ ). It was observed that the sample FMAL-10 with 10 wt. \% of $\mathrm{Fe}_{3} \mathrm{O}_{4}$, exhibited the highest $\mathrm{CO}$ and $\mathrm{CH}_{4}$ yield, and hence, it was selected 
as an optimized sample. The key factors as explained above were supposed to be the efficient charge separation by the $\mathrm{Fe}_{3} \mathrm{O}_{4}$ content and the rapid transformation of the photoexcited charges towards the reactive sites on $\mathrm{Fe}_{3} \mathrm{O}_{4} / \mathrm{Mg}$ - $\mathrm{Al} \mathrm{LDH}$ surface. Further increase of $\mathrm{Fe}_{3} \mathrm{O}_{4}$ content decreased the light transmission characteristic and hence reduced photocatalytic performance.

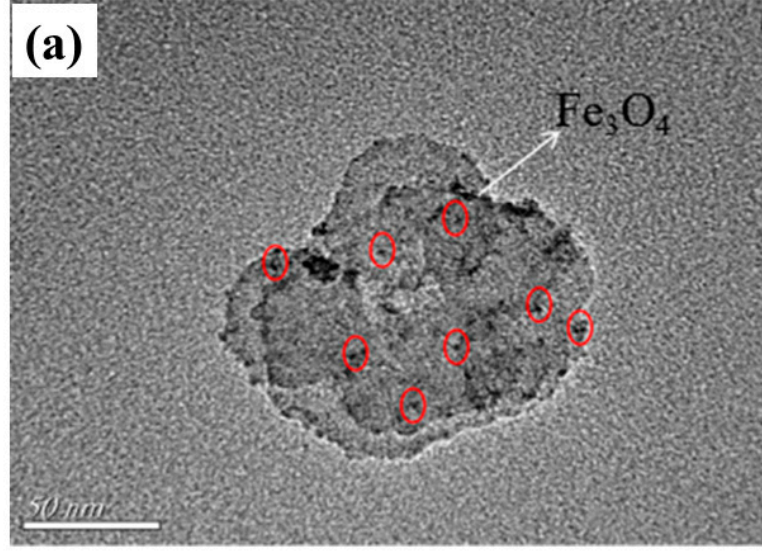

(c)

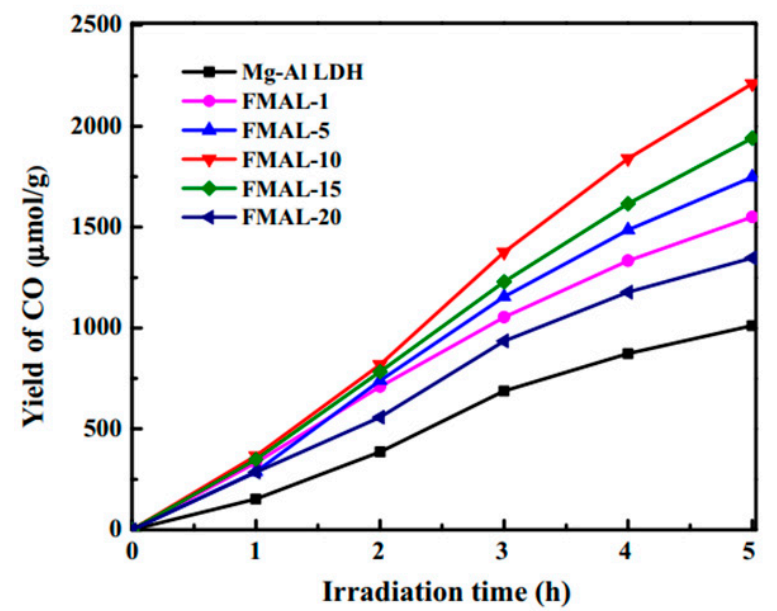

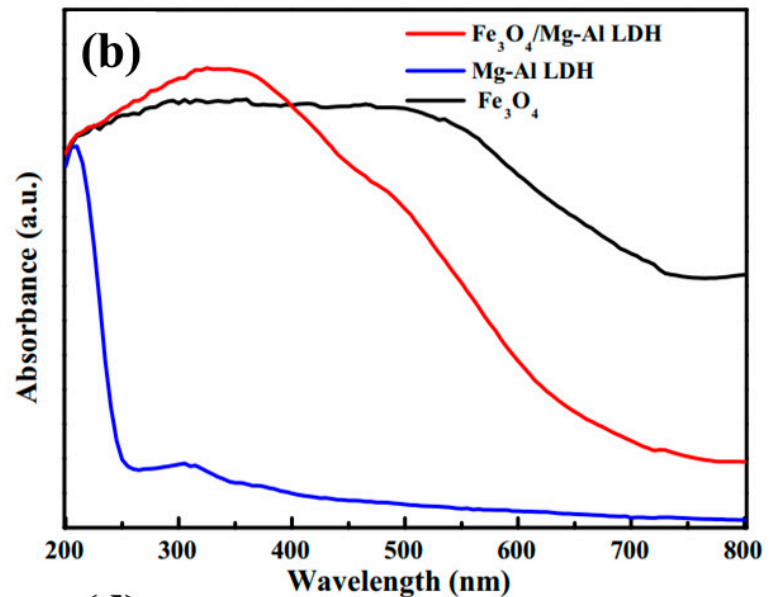

(d)

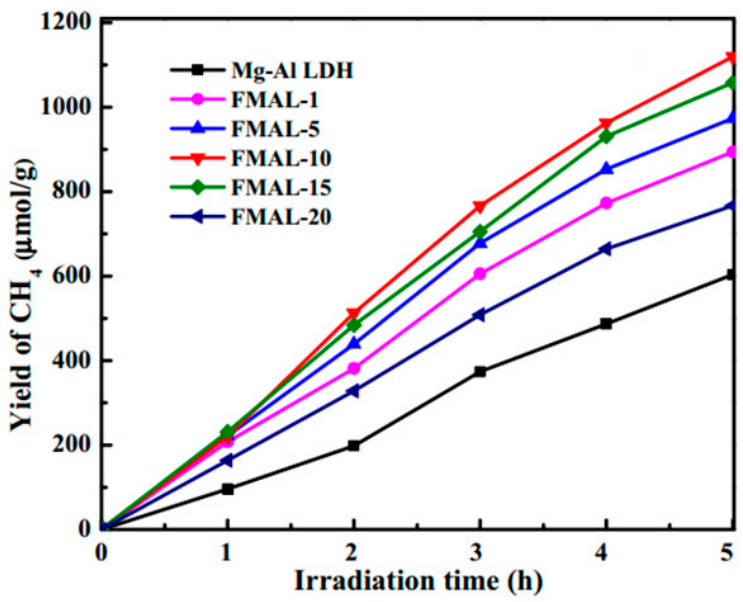

Figure 7. (a) Surface morphology of the $\mathrm{Fe}_{3} \mathrm{O}_{4} / \mathrm{Mg}-\mathrm{Al} \mathrm{LDH}$. (b) UV-Vis DRS for $\mathrm{Fe}_{3} \mathrm{O}_{4} / \mathrm{Mg}-\mathrm{Al} \mathrm{LDH}$, $\mathrm{Mg}$-AL LDH and $\mathrm{Fe}_{3} \mathrm{O}_{4}$. (c,d) Photocatalytic $\mathrm{CO}_{2}$ conversion to $\mathrm{CO}$ and $\mathrm{CH}_{4}$, respectively, for various $\mathrm{Fe}_{3} \mathrm{O}_{4} / \mathrm{Mg}-\mathrm{Al} \mathrm{LDH}$, represented by FMAL with varied amount of $\mathrm{Fe}_{3} \mathrm{O}_{4}$ (Figures taken with permission from reference [53]. Copyright 2019, Elsevier).

Recently, Bai et al. reported four different types of ultrathin MAl-LDH photocatalysts (u-MAl-LDH, where $\mathrm{M}$ stands for $\mathrm{Mg}^{2+}, \mathrm{Ni}^{2+}, \mathrm{CO}^{2+}$ and $\mathrm{Zn}^{2+}$ ) for $\mathrm{CO}_{2}$ conversion to mainly $\mathrm{CO}$ [54]. The synthesized u-MAl-LDH were tested under visible light irradiation $(\lambda=400-800 \mathrm{~nm})$ and employed with a $\left[\mathrm{Ru}(\mathrm{bpy})_{3}\right] \mathrm{Cl}_{2} \cdot 6 \mathrm{H}_{2} \mathrm{O}$ photosensitizer for photocatalytic $\mathrm{CO}_{2}$ conversion to $\mathrm{CO}$. Amongst various samples synthesized, the u-CoAl-LDH showed the highest efficiency, Figure 8a shows the schematic view of proposed photocatalytic $\mathrm{CO}_{2}$ conversion employing u-CoAl-LDH with production of $\mathrm{CO}$ and $\mathrm{H}_{2}$ when irradiated with visible light $(400-800 \mathrm{~nm})$ and light at $600 \mathrm{~nm}$ wavelength. Figure $8 \mathrm{~b}$ shows that the photocatalytic reactions were not initiated without $\left[\mathrm{Ru}(\mathrm{bpy})_{3}\right] \mathrm{Cl}_{2} \cdot 6 \mathrm{H}_{2} \mathrm{O}$ and triethanolamine, thus endorsing the important roles of $\left[\mathrm{Ru}(\mathrm{bpy})_{3}\right] \mathrm{Cl}_{2} \cdot 6 \mathrm{H}_{2} \mathrm{O}$ as a photosensitizer and triethanolamine as a hole scavenger for regeneration of LDH photocatalysts valence bands. Figure $8 \mathrm{c}$ illustrates the photocatalytic $\mathrm{CO}_{2}$ conversion products for all the synthesized u-MAl-LDH photocatalysts. It could be observed that all samples exhibit less amount of $\mathrm{CO}$ and $\mathrm{H}_{2}$ production as than u-CoAl-LDH, which exhibited the highest conversion rate. The $\mathrm{u}-\mathrm{NiAl}-\mathrm{LDH}$ sample also exhibited production of 
$\mathrm{CH}_{4}$ due to well-known selectivity of $\mathrm{Ni}$ towards $\mathrm{CH}_{4}$. The key reason for improved photocatalytic performance can be associated to (i) defects on the photocatalyst surface due to its ultrathin nature thus promoting the $\mathrm{CO}_{2}$ adsorption; (ii) improved light absorption, thus capturing the maximum of visible light region; and (iii) well matched energy levels of $\mathrm{u}-\mathrm{CoAl}-\mathrm{LDH}$ with $\left[\mathrm{Ru}(\mathrm{bpy})_{3}\right] \mathrm{Cl}_{2} \cdot 6 \mathrm{H}_{2} \mathrm{O}$ photosensitizer, thus on light irradiation the photogenerated charges are drained towards the LDH surface where they can efficiently react with the adsorbed $\mathrm{CO}_{2}$.

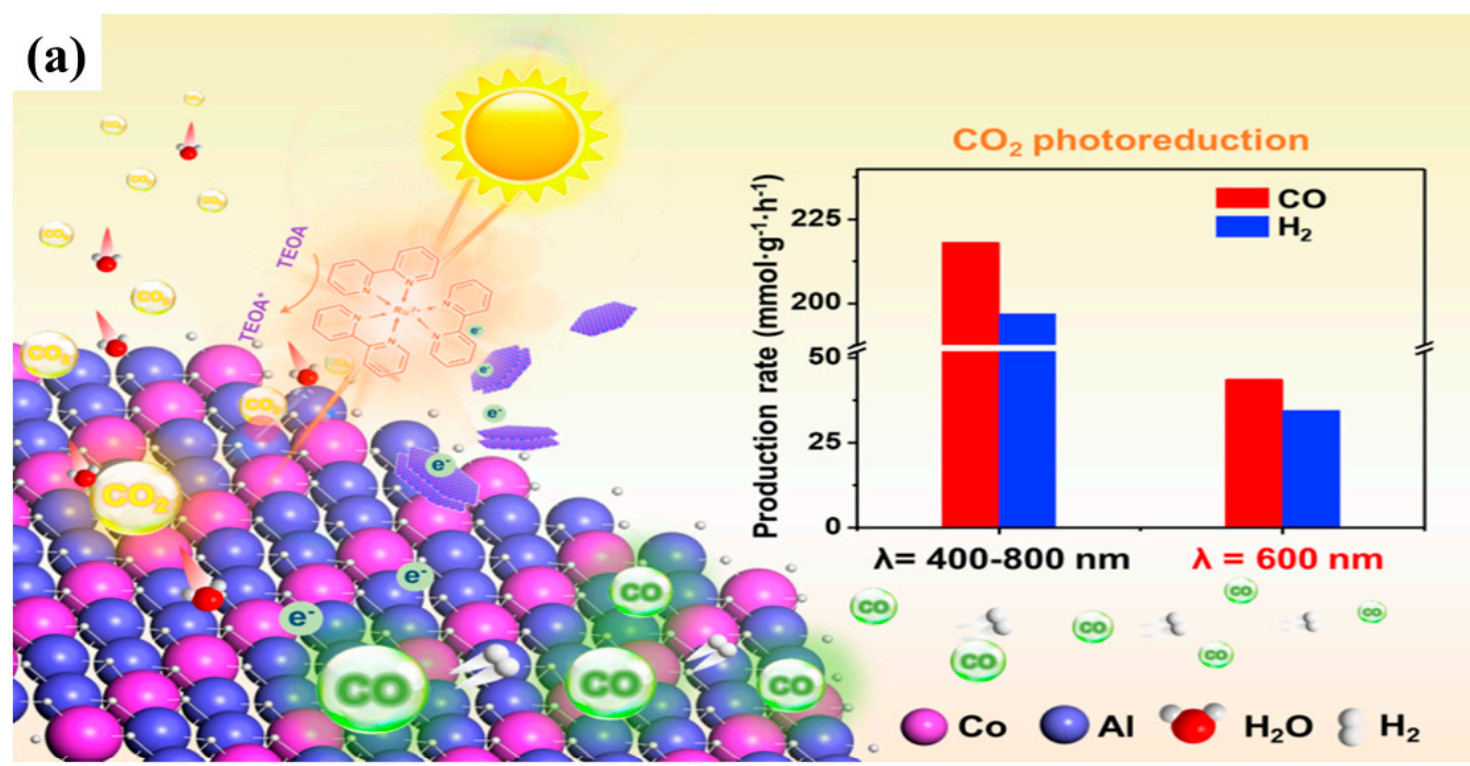

(b)

(c)
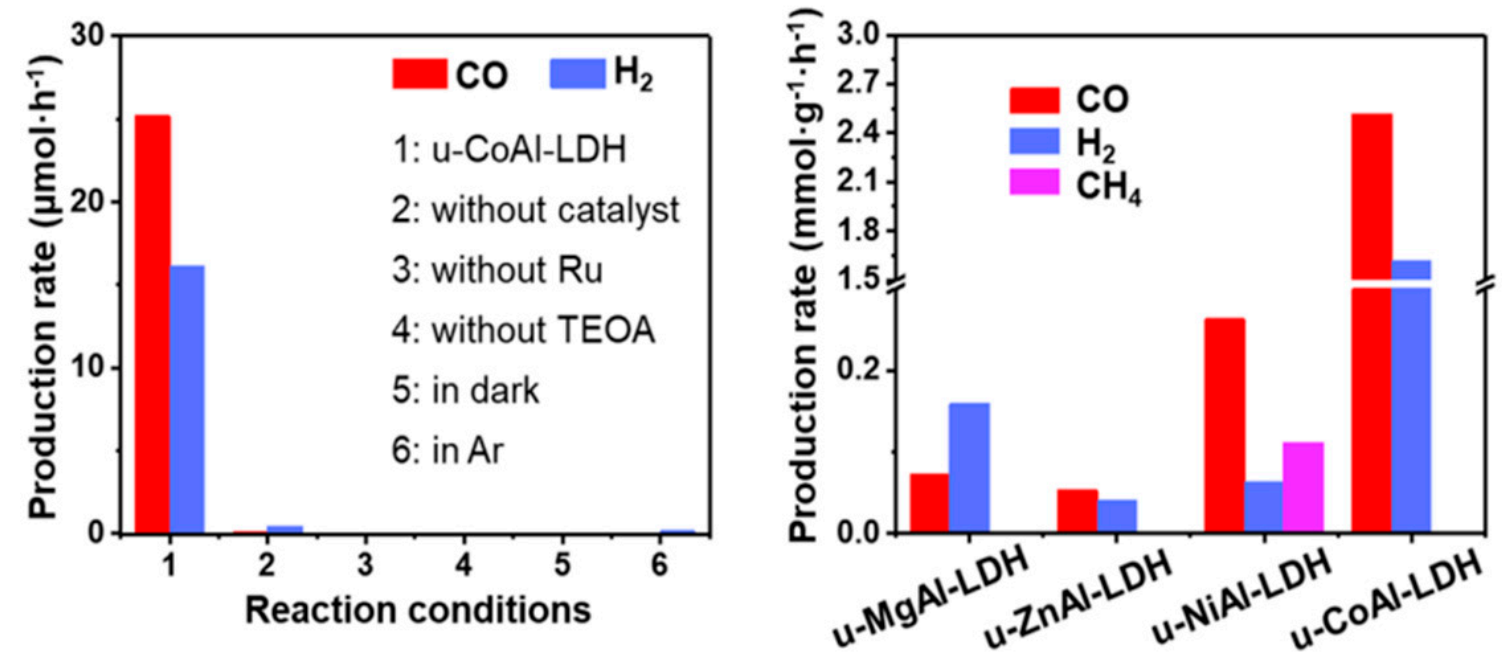

Figure 8. Photocatalytic $\mathrm{CO}_{2}$ conversion to $\mathrm{CO}, \mathrm{CH}_{4}$, and $\mathrm{H}_{2}$ over (a) ultrathin $\mathrm{CoAl}-\mathrm{LDH}$, (b) under various conditions, and (c) with different ultrathin $\mathrm{LDH}$ photocatalysts. (Figures taken with permission from reference [54]. Copyrights 2020, American chemical society).

Another work proposed by Xiong et al. presented the role of trivalent and tetravalent in $\mathrm{Zn}$ based LDH photocatalysts employed for photocatalytic $\mathrm{CO}_{2}$ conversion [55]. It was observed that choice of trivalent or tetravalent cation in the LDH photocatalyst alters the selectivity of the product. Authors synthesized a variety of $\mathrm{ZnM}-\mathrm{LDH}$ (where $\mathrm{M}=\mathrm{Ti}^{4+}, \mathrm{Fe}^{3+}, \mathrm{Co}^{3+}, \mathrm{Ga}^{3+}, \mathrm{Al}^{3+}$ ) and observed that $\mathrm{ZnTi}-\mathrm{LDH}$ generates $\mathrm{CH}_{4}$ as main product, whereas $\mathrm{ZnFe}-\mathrm{LDH}$ and $\mathrm{ZnCo}-\mathrm{LDH}$ were unable to reduce $\mathrm{CO}_{2}$ and yield $\mathrm{H}_{2}$ by water splitting only. Moreover, $\mathrm{ZnGa-LDH}$ and $\mathrm{ZnAl}-\mathrm{LDH}$ yielded $\mathrm{CO}$ as main product of $\mathrm{CO}_{2}$ photo-reduction. By help of in situ diffuse reflection, infrared Fourier transform spectroscopy (DRIFT), and computational calculations, it was revealed that the metal cations with $\mathrm{d}$ 
band level $\left(\varepsilon_{d}\right)$ closer to the fermi level interact favorably with $\mathrm{CO}_{2}$, leading to its well adsorption, and hence, light irradiation converts the adsorbed $\mathrm{CO}_{2}$ into carbon containing products, i.e., $\mathrm{CH}_{4}$ and $\mathrm{CO}$, whereas the metals with $\mathrm{d}$ band level far from the fermi level exhibited very less $\mathrm{CO}_{2}$ adsorption, thus yielding $\mathrm{H}_{2}$ due to water splitting. Figure 9a shows the mechanistic view of the synthesized $\mathrm{ZnM}-\mathrm{LDH}$ photocatalysts and their selectivity to certain products. Figure $9 \mathrm{~b}$ shows the photocatalytic product generated by the ZnM-LDH photocatalysts, and Figure 9c exhibits the respective selectivity.

(a)
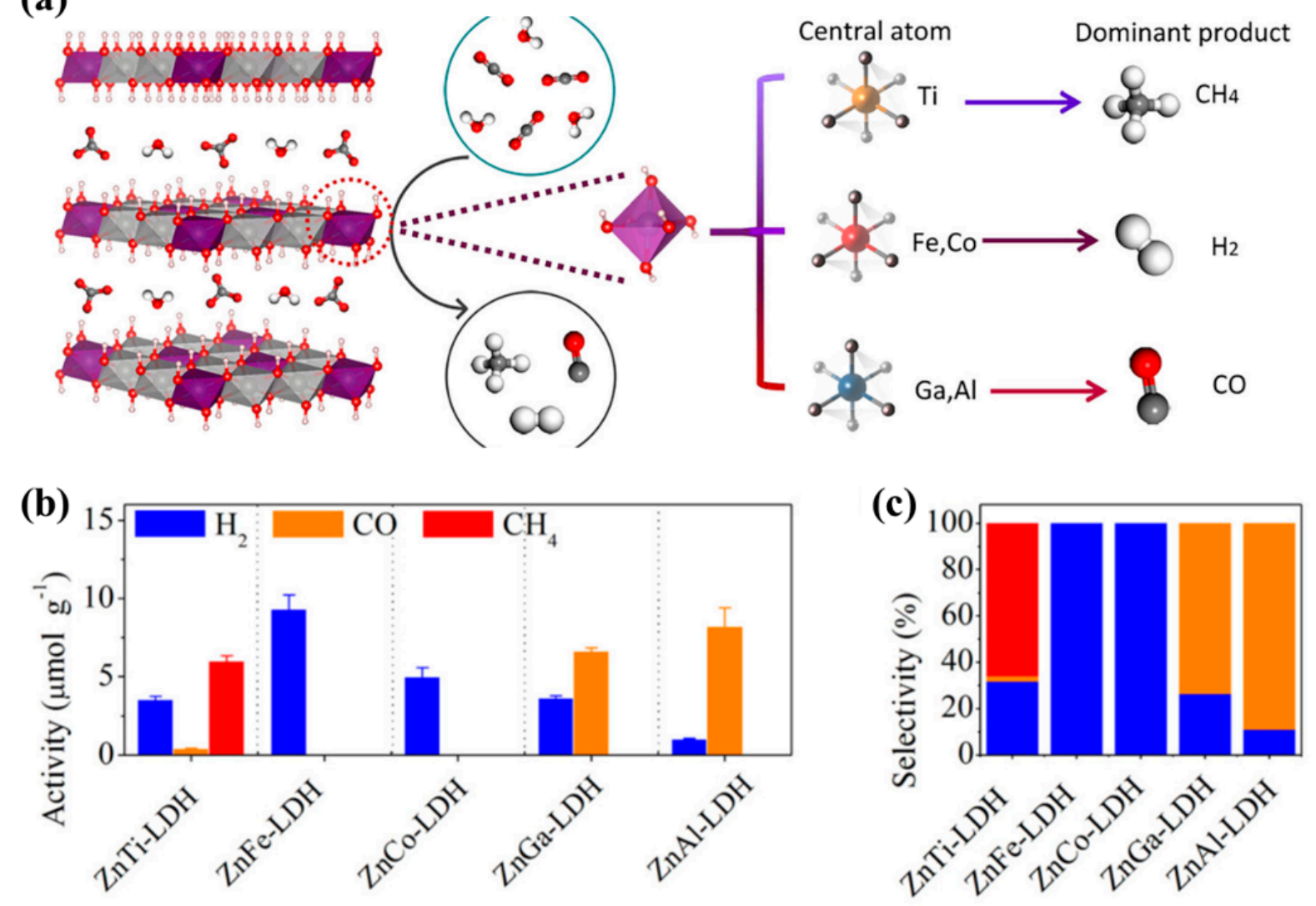

Figure 9. (a) Mechanistic view of various products obtained from different $\mathrm{Zn}$ based LDH (ZnM-LDH, where $\mathrm{M}=\mathrm{Ti}, \mathrm{Fe}, \mathrm{Co}, \mathrm{Ga}, \mathrm{Al}$ ) photocatalysts. (b) Photocatalytic $\mathrm{CO}_{2}$ conversion to useful chemicals. (c) Selectivity for various ZnM-LDH photocatalysts. (Figures taken with permission from reference [55]. Copyright 2020, Elsevier).

In addition to the development of LDH photocatalysts, another important and beneficial approach is to use the $\mathrm{LDH}$ as a base material to convert it into a highly efficient photocatalyst. Recently, Wang et al. fabricated thin and defective $\mathrm{NiO} / \mathrm{Al}_{2} \mathrm{O}_{3}$ composite from NiAl-LDH [56]. The NiAl-LDH photocatalyst was transformed to $\mathrm{NiO}$ with $\mathrm{Ni}$ and oxygen vacancies under oxidation and was investigated at various oxidation temperatures from $200-800{ }^{\circ} \mathrm{C}$. The schematic view of the proposed mechanism for synthesis methodology is exhibited in Figure 10a. The photocatalytic $\mathrm{CO}_{2}$ conversion to various products with selectivity can be seen in Figure 10b,c, respectively. It could be observed, $\mathrm{NiO}$ sample synthesized at a temperature of $275{ }^{\circ} \mathrm{C}$, yielded maximum $\mathrm{CH}_{4}$ under the irradiation of $600 \mathrm{~nm}$ wavelength light. Hence, this temperature meant to be an optimum condition for having the best oxygen and nickel vacancies.

The summary of the various bare/pure LDH photocatalysts regarding their research objective, reaction conditions, products yielded, and influential parameters are tabulated in Table 1. 
Table 1. Summary of various pure/bare $\mathrm{LDH}$ photocatalysts with research objective, reaction conditions, value added chemicals production by photocatalytic $\mathrm{CO}_{2}$ conversion, and key parameters for improved performance.

\begin{tabular}{|c|c|c|c|c|c|}
\hline LDH Photocatalysts & Research Objective & $\begin{array}{l}\text { Light Source and } \\
\text { Reactants Employed }\end{array}$ & $\begin{array}{c}\text { Photocatalytic Activity, } \mathrm{CO}_{2} \\
\text { Conversion to Value Added } \\
\text { Chemicals }\end{array}$ & $\begin{array}{l}\text { Parameters Contributing towards } \\
\text { Improved Performance }\end{array}$ & Ref \\
\hline $\begin{array}{l}\mathrm{ZnCuGa} \mathrm{LDH} \text { and } \\
\mathrm{ZnCuAl} \mathrm{LDH}\end{array}$ & $\begin{array}{l}\text { Development of } \\
\text { UV-Visible light active } \\
\text { LDH with tailoring the } \\
\text { product selectivity via } \\
\text { Zn and Cu sites }\end{array}$ & $\begin{array}{l}\text { UV-visible light } \\
\text { obtained from } 500 \mathrm{~W} \\
\text { Xenon arc lamp } \\
\mathrm{CO}_{2} \text { with } \mathrm{H}_{2} \text { gas } \\
\text { were used } \\
\text { as reactants }\end{array}$ & $\begin{array}{l}\text { - } \mathrm{ZnCuGa} \mathrm{LDH} \\
\text { selectively produces } \\
\mathrm{CH}_{3} \mathrm{OH}: 179 \mathrm{nmol} \mathrm{g}^{-1} \\
\mathrm{~h}^{-1}(68 \mathrm{~mol} \% \text {, } \\
\text { selectivity) and CO: } 79 \\
\text { nmol g }{ }^{-1} \mathrm{~h}^{-1} \\
\text { - } \mathrm{ZnCuAl} \mathrm{LDH} \mathrm{was} \\
\text { selective to produce CO: } \\
82 \text { nmol g }{ }^{-1} \mathrm{~h}^{-1} \text { with a } \\
\text { selectivity of } 94 \text { mol.\% }\end{array}$ & $\begin{array}{l}\text { - LDH prepared were UV-Vis } \\
\text { light active material with } \\
\text { improved } \mathrm{CO}_{2} \text { adsorption } \\
\text { The inclusion of } \mathrm{Cu} \text { sites } \\
\text { improves the } \\
\mathrm{CH}_{3} \mathrm{OH} \text { selectivity } \\
\text { - The key to } \mathrm{CH}_{3} \mathrm{OH} \text { vs. } \mathrm{CO} \\
\text { selectivity was attributed to } \\
\text { the binding nature of } \mathrm{CO}_{2} \text { at } \\
\mathrm{Cu} \text { species in form } \\
\text { of carbonates }\end{array}$ & [45] \\
\hline $\begin{array}{l}\mathrm{ZnCuGa} \mid \mathrm{Cu}(\mathrm{OH})_{4} \\
\mathrm{LDH}\end{array}$ & $\begin{array}{l}\text { Development of } \\
\mathrm{ZnCuGa|Cu}(\mathrm{OH})_{4} \mathrm{LDH} \\
\text { by replacing the anions } \\
\text { in } \mathrm{ZnCuGa} \mid \mathrm{CO}_{3} \text { and } \\
\text { investigation of metal } \\
\text { cations composition } \\
\text { ratio of product } \\
\text { selectivity and } \mathrm{CO}_{2} \\
\text { photoreduction efficiency }\end{array}$ & $\begin{array}{l}\text { UV-visible light } \\
\text { obtained from } 500 \mathrm{~W} \\
\text { Xenon arc lamp } \\
\text { - } \mathrm{CO}_{2} \text { with } \mathrm{H}_{2} \text { gas as } \\
\text { a reductant }\end{array}$ & $\begin{array}{l}\text { Photoreduction of } \mathrm{CO}_{2} \\
\text { to } \mathrm{CH}_{3} \mathrm{OH} \text { for } \\
\mathrm{Zn}_{3} \mathrm{Ga} \mid \mathrm{Cu}(\mathrm{OH})_{4} \mathrm{LDH} \\
\text { was obtained } \\
0.49 \mu \mathrm{mol} \mathrm{g}^{-1} \mathrm{~h}^{-1} \text { with } \\
88 \mathrm{~mol} \% \text { selectivity } \\
\text { which is } 5.9 \text { times higher } \\
\text { as compared to } \\
\mathrm{ZnCuGa|CO} \mathrm{CO}_{3}\end{array}$ & $\begin{array}{l}\text { - The stearic availability for the } \\
{\left[\mathrm{Cu}(\mathrm{OH})_{4}\right]^{2-} \text { is attributed to }} \\
\text { play the role in enhanced } \\
\mathrm{CH}_{3} \mathrm{OH} \text { formation rate } \\
\text { - The narrower bandgap value } \\
\text { also contributes to the } \\
\text { photocatalytic performance } \\
\text { The hydroxy groups bounded } \\
\text { to } \mathrm{Cu} \text { sites plays an important } \\
\text { role in the } \mathrm{CH}_{3} \mathrm{OH} \text { production }\end{array}$ & [46] \\
\hline
\end{tabular}


Table 1. Cont

\begin{tabular}{|c|c|c|c|c|c|}
\hline LDH Photocatalysts & Research Objective & $\begin{array}{l}\text { Light Source and } \\
\text { Reactants Employed }\end{array}$ & $\begin{array}{c}\text { Photocatalytic Activity, } \mathrm{CO}_{2} \\
\text { Conversion to Value Added } \\
\text { Chemicals }\end{array}$ & $\begin{array}{l}\text { Parameters Contributing towards } \\
\text { Improved Performance }\end{array}$ & Ref \\
\hline $\begin{array}{c}\text { Various } \mathrm{M}-\mathrm{Al}(\mathrm{M}= \\
\mathrm{Mg}, \mathrm{Zn} \text { and } \mathrm{Ni}) \mathrm{LDH} \\
\text { and } \mathrm{M}-\mathrm{Ni} \mathrm{LDH} \text { (where } \\
\mathrm{M}=\mathrm{Mg}, \mathrm{Zn}) \text { prepared } \\
\text { from aqueous solution } \\
\text { of metal nitrates and } \\
\text { chlorides }\end{array}$ & 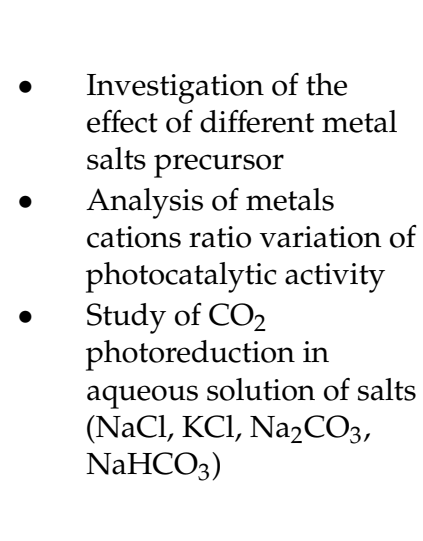 & $\begin{array}{ll}\text { - } & \text { UV-visible light } \\
\text { - Obtained from } 400 \mathrm{~W} \\
\mathrm{Hg} \text { high pressure lamp } \\
\mathrm{CO}_{2} \text { with } \mathrm{H}_{2} \mathrm{O} \text { and } \\
\text { aqueous solution of salts } \\
\left(\mathrm{NaCl}, \mathrm{KCl}, \mathrm{Na}_{2} \mathrm{CO}_{3}\right. \\
\left.\mathrm{NaHCO}_{3}\right) \text { were used in } \\
\text { a closed system }\end{array}$ & 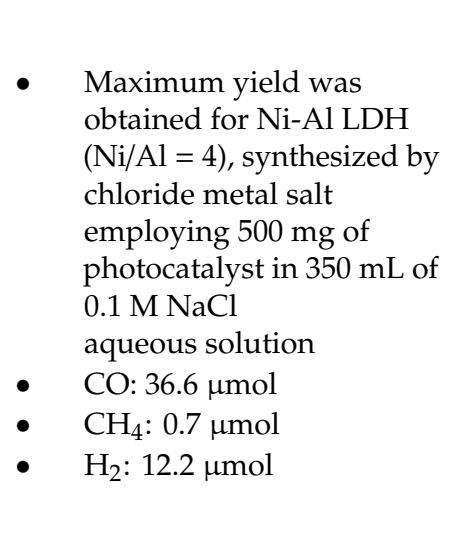 & $\begin{array}{l}\text { The Ni-Al LDH prepared by } \\
\text { chloride metal salt precursor } \\
\text { compensate the } \\
\text { photogenerated charges well } \\
\text { than } \mathrm{LDH} \text { prepared from } \\
\mathrm{NO}_{3} \text { salts } \\
\mathrm{CO}_{2} \text { photoreduction in } \mathrm{NaCl} \\
\text { solution exhibits maximum } \\
\text { performance which was } \\
\text { attributed to the presence of } \\
\text { interlayer } \mathrm{Cl}^{-} \text {ion in aqueous } \\
\text { solution acting as a hole } \\
\text { scavenger under } \mathrm{UV} \\
\text { light irradiation }\end{array}$ & [47] \\
\hline $\begin{array}{l}\mathrm{Ni}-\mathrm{Al} \mathrm{LDH} \text { (Chloride } \\
\quad \text { ion, } \mathrm{Cl}^{-} \text {effect) }\end{array}$ & $\begin{array}{l}\text { Investigation regarding } \\
\text { the } \mathrm{Cl}^{-} \text {ion effect as a } \\
\text { holes scavenger on } \\
\mathrm{CO}_{2} \text { photoreduction }\end{array}$ & $\begin{array}{ll}\text { - } & \text { UV-visible light } \\
\text { Obtained from } 400 \mathrm{~W} \\
\text { high pressure } \mathrm{Hg} \text { lamp } \\
\mathrm{CO}_{2} \text { bubbled in aqueous } \\
\text { solution of the } \mathrm{NaCl} \\
\text { containing } \\
\text { suspended photocatalyst }\end{array}$ & $\begin{array}{l}\text { - } \mathrm{Ni-Al} \text { LDH within } 0.1 \mathrm{M} \\
\mathrm{NaCl} \text { solution, } 0.5 \mathrm{~g} \text { of } \\
\text { suspended photocatalysts } \\
\text { and } 8 \mathrm{~h} \text { of light } \\
\text { irradiation produces: } \\
\text { - } \quad \mathrm{CO}: 56.4 \mu \mathrm{mol} \\
\text { - } \quad \mathrm{H}_{2}: 9.3 \mu \mathrm{mol} \\
\text { - } \quad \text { with selectivity towards } \\
\text { CO of } 86 \mathrm{~mol} \% \\
\text { - } \mathrm{After} 29 \mathrm{~h} \text { of irradiation } \\
\text { CO: } 110.9 \mu \text { molwith } \\
\text { selectivity towards CO of } \\
88.4 \text { mol. } \%\end{array}$ & $\begin{array}{l}\text { The chloride ions }\left(\mathrm{Cl}^{-}\right) \text {in the } \\
\text { aqueous solution of } \mathrm{NaCl} \\
\text { improved the } \mathrm{CO}_{2} \text { reduction } \\
\text { via clear suppression of } \mathrm{H}_{2} \\
\text { production and acts as an } \\
\text { efficient hole scavenger }\end{array}$ & [48] \\
\hline
\end{tabular}


Table 1. Cont

\begin{tabular}{|c|c|c|c|c|c|}
\hline LDH Photocatalysts & Research Objective & $\begin{array}{l}\text { Light Source and } \\
\text { Reactants Employed }\end{array}$ & $\begin{array}{c}\text { Photocatalytic Activity, } \mathrm{CO}_{2} \\
\text { Conversion to Value Added } \\
\text { Chemicals }\end{array}$ & $\begin{array}{l}\text { Parameters Contributing towards } \\
\text { Improved Performance }\end{array}$ & Ref \\
\hline $\begin{array}{l}\text { Fluorinated } \\
\text { Ni-Al LDH } \\
\text { and } \\
\text { Fluorinated } \\
\text { Mg-Al LDH }\end{array}$ & $\begin{array}{l}\text { Investigation of } \\
\text { fluorination of } \mathrm{LDH} \\
\text { surfaces and its effect on } \\
\mathrm{CO}_{2} \text { photoreduction in } \\
\text { aqueous solution. }\end{array}$ & $\begin{array}{l}\text { - UV-visible light } \\
\text { obtained from } 400 \mathrm{~W} \mathrm{Hg} \\
\text { high pressure lamp } \\
\mathrm{CO}_{2} \text { bubbled in water } \\
\text { with } \\
\text { suspended photocatalysts }\end{array}$ & $\begin{array}{l}\text { Fluorinated } \mathrm{Ni}-\mathrm{Al} \mathrm{LDH} \text {, } \\
\text { with } 7.5 \text { ratio of } \mathrm{Na}_{2} \mathrm{AlF}_{6} \\
\text { in total } \mathrm{Al} \text { species } \\
\left(\mathrm{Na}_{2} \mathrm{AlF}_{6}+\mathrm{AlCl}_{3}\right) \text { with } \\
0.5 \text { g suspended } \\
\text { photocatalysts in } 350 \mathrm{~mL} \\
\text { of } 0.1 \mathrm{M} \mathrm{NaCl} \text { solution } \\
\text { The maximum } \mathrm{CO}_{2} \\
\text { conversion rate producing } \\
\text { CO: } 93.3 \mu \text { molafter } 20 \mathrm{~h} \\
\text { irradiation and selectivity } \\
\text { of } 80 \%\end{array}$ & $\begin{array}{l}\text { - Fluorination incorporates the } \\
\left(\mathrm{AlF}_{6}\right)^{-3} \text { units in } \mathrm{LDH} \text { sheets, } \\
\text { an important parameter } \\
\text { leading to better } \mathrm{CO}_{2} \\
\text { adsorption and } \mathrm{Cl}^{-} \text {ion in } \\
\text { aqueous solution suppressing } \\
\mathrm{H}_{2} \text { formation and acting as a } \\
\text { hole scavenger }\end{array}$ & [49] \\
\hline Mg-Al LDH & $\begin{array}{l}\text { Investigating the effect } \\
\text { of various } \mathrm{Mg}^{+2} \\
\text { precursor (acetates and } \\
\text { nitrates) and microwave } \\
\text { irradiation time for } \\
\text { conversion of } \mathrm{CO}_{2} \text { by } \\
\mathrm{Mg}-\mathrm{Al} \mathrm{LDH}\end{array}$ & $\begin{array}{l}\text { - Solar simulator using } \\
150 \mathrm{~W} \text { Xe lamp } \\
\text { Reaction is carried out in } \\
\text { both liquid and gas } \\
\text { phase with } \mathrm{CO}_{2} \text { and } \\
\mathrm{H}_{2} \mathrm{O} \text { as reactants }\end{array}$ & 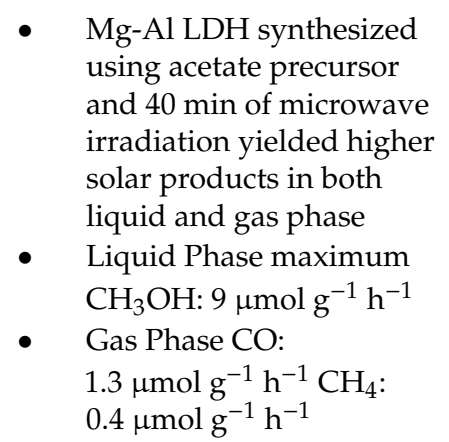 & $\begin{array}{l}\text { - } \quad \text { An optimal cut off various } \\
\text { parameters enhanced the } \\
\text { photocatalytic performance } \\
\text { which includes the following: } \\
\text { - } \quad \text { LDH Crystallinity } \\
\text { - } \quad \text { Flat band potential } \\
\text { - } \mathrm{CO}_{2} \text { adsorption } \\
\text { - } \quad \text { Charge transfer resistance }\end{array}$ & {$[50]$} \\
\hline
\end{tabular}


Table 1. Cont

\begin{tabular}{|c|c|c|c|c|c|}
\hline LDH Photocatalysts & Research Objective & $\begin{array}{l}\text { Light Source and } \\
\text { Reactants Employed }\end{array}$ & $\begin{array}{c}\text { Photocatalytic Activity, } \mathrm{CO}_{2} \\
\text { Conversion to Value Added } \\
\text { Chemicals }\end{array}$ & $\begin{array}{l}\text { Parameters Contributing } \\
\text { towards Improved Performance }\end{array}$ & Ref \\
\hline Co-Al LDH & $\begin{array}{l}\text { The nanosheets of } \mathrm{Co}-\mathrm{Al} \\
\text { LDH were synthesized } \\
\text { and applied for } \\
\text { atmospheric } \mathrm{CO}_{2} \\
\text { conversion to useful } \\
\text { products } \mathrm{CO} \text { and } \mathrm{CH}_{4}\end{array}$ & $\begin{array}{l}\text { - Simulated solar light } \\
\text { obtained using } 500 \mathrm{~W} \\
\text { Xe lamp } \\
\mathrm{CO}_{2} \text { and } \mathrm{H}_{2} \mathrm{O} \text { vapors } \\
\text { were employed as } \\
\text { reactants under gaseous } \\
\text { closed system }\end{array}$ & $\begin{array}{l}\text { Co-Al } \mathrm{LDH} \text { nanosheets } \\
\text { yielded } \mathrm{CH}_{4}: \\
4.3 \mu \mathrm{mol} \mathrm{g}^{-1} \mathrm{~h}^{-1} \text { after } 5 \mathrm{~h} \\
\text { of irradiation and the yield } \\
\text { reaches to } 90 \% \text { selectivity } \\
\text { in } 55 \mathrm{~h} \text { of reaction }\end{array}$ & $\begin{array}{l}\text { - } \quad \text { Better light adsorption as } \\
\text { band gap is } 2.1 \mathrm{eV} \\
\text { - } \quad \text { Surface alkaline } \mathrm{OH} \text { groups } \\
\text { for better } \mathrm{CO}_{2} \text { adsorption } \\
\text { - } \quad \text { Divalent } \mathrm{Co} \text { for efficient } \\
\text { water splitting producing } \\
\mathrm{H}_{2} \text { for } \\
\text { hydrogenation reactions }\end{array}$ & [51] \\
\hline $\begin{array}{l}\text { Nano crystals of Ni-Al } \\
\text { LDH }\end{array}$ & $\begin{array}{l}\text { Development of } \\
\text { nanocrystals of } \mathrm{Ni}-\mathrm{Al} \\
\mathrm{LDH} \text { for enhanced } \\
\mathrm{CO}_{2} \text { photoreduction }\end{array}$ & $\begin{array}{l}\text { - Light is obtained from } \\
\mathrm{Hg} \text { high pressure Lamp } \\
\text { of } 400 \mathrm{~W} \\
\mathrm{CO}_{2} \text { gas was bubbled } \\
\text { through aqueous } \\
\text { solution of } 0.1 \mathrm{M} \mathrm{NaCl} \\
\text { with suspended } \\
\text { photocatalyst }(1.0 \mathrm{~g})\end{array}$ & $\begin{array}{l}\text { - } \mathrm{Ni}-\mathrm{Al} \mathrm{LDH} \text { synthesized } \\
\text { from nanocrystals (around } \\
20 \mathrm{~nm} \text { ) produces CO: } \\
50 \mu \mathrm{mol} \mathrm{h}^{-1}, \text { which is } 7 \\
\text { times greater than } \\
\text { standard crystalline } \\
\text { Ni-Al LDH }\end{array}$ & $\begin{array}{l}\text { The high surface affinity of } \\
\text { the nano Ni-Al LDH to } \mathrm{CO}_{2} \\
\text { is attributed to the } \\
\text { enhanced performance } \\
\text { Such specific surface } \\
\text { property is related to the } \\
\text { quenching of the metastable } \\
\text { surface by rapid hydroxide } \\
\text { formation form the } \\
\text { respective molten salts }\end{array}$ & [52] \\
\hline $\begin{array}{l}\text { Ultrathin magnetic } \\
\mathrm{Mg} \text {-Al LDH } \\
\text { represented as } \\
\mathrm{Fe}_{3} \mathrm{O}_{4} / \mathrm{Mg}-\mathrm{Al} \mathrm{LDH}\end{array}$ & $\begin{array}{l}\text { - Synthesis of 2-D } \\
\text { ultrathin magnetic } \\
\mathrm{Mg}-\mathrm{Al} \mathrm{LDH} \text { by coupling } \\
\text { with } \mathrm{Fe}_{3} \mathrm{O}_{4} \text { for enhanced } \\
\mathrm{CO}_{2} \text { photoreduction and } \\
\text { recyclability of } \\
\text { the photocatalyst }\end{array}$ & $\begin{array}{l}\text { - Ultraviolet light is } \\
\text { obtained from } 8 \mathrm{~W} \text { lamp } \\
\mathrm{CO}_{2} \text { gas was passed } \\
\text { through solution of } 0.1 \\
\mathrm{M} \mathrm{NaOH}(70 \mathrm{~mL}) \text { and } \\
\text { acetonitrile }(5 \mathrm{~mL}) \text { with } \\
\text { photocatalyst }(0.05 \mathrm{~g}) \\
\text { suspended in it }\end{array}$ & $\begin{array}{l}\mathrm{Fe}_{3} \mathrm{O}_{4} / \mathrm{Mg}-\mathrm{Al} \mathrm{LDH} \text { with } \\
10 \% \text { of } \mathrm{Fe}_{3} \mathrm{O}_{4} \text { content } \\
\text { exhibited the maximum } \\
\text { yield with production rate } \\
\text { of, } \mathrm{CO}: 442.3 \mu \mathrm{mol} \mathrm{g}^{-1} \mathrm{~h}^{-1} \\
\mathrm{CH}_{4}: 223.9 \mu \mathrm{mol} \mathrm{g}^{-1} \mathrm{~h}^{-1}\end{array}$ & $\begin{array}{l}\text { - } \mathrm{Fe}_{3} \mathrm{O}_{4} \text { induces synergetic } \\
\text { effect of photogenerated } \\
\text { charges separation } \\
\text { The 2D ultra-thin } \mathrm{Mg}-\mathrm{Al} \\
\text { LDH also reduces the } \\
\text { transmission resistance of } \\
\text { charge carriers resulting in } \\
\text { increased reactions sites }\end{array}$ & [53] \\
\hline
\end{tabular}


Table 1. Cont.

\begin{tabular}{|c|c|c|c|c|c|}
\hline LDH Photocatalysts & Research Objective & $\begin{array}{l}\text { Light Source and } \\
\text { Reactants Employed }\end{array}$ & $\begin{array}{c}\text { Photocatalytic Activity, } \mathrm{CO}_{2} \\
\text { Conversion to Value Added } \\
\text { Chemicals }\end{array}$ & $\begin{array}{l}\text { Parameters Contributing towards } \\
\text { Improved Performance }\end{array}$ & Ref \\
\hline $\begin{array}{c}\mathrm{u}-\mathrm{MAl} \mathrm{LDH}, \text { where } \\
\mathrm{M}=\mathrm{Mg}^{2+}, \mathrm{Co}^{2+} \\
\mathrm{Ni}^{2+} \text {, and } \mathrm{Zn}^{2+}\end{array}$ & 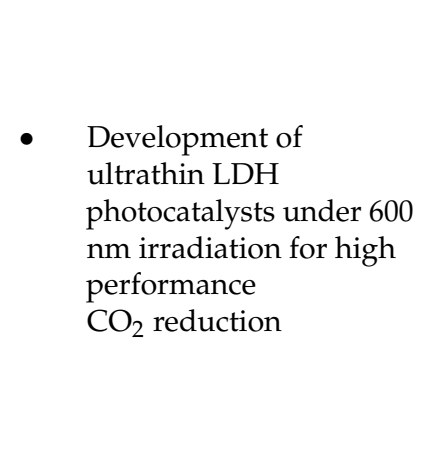 & $\begin{array}{l}\text { - Light is obtained } \\
(400-800 \mathrm{~nm}) \text { from } \\
\text { Xenon Lamp of } \\
300 \mathrm{~W} \\
\mathrm{CO}_{2} \text { was bubbled } \\
\text { through the solution } \\
\text { containing } \\
\text { TEOA/ } \mathrm{H}_{2} \mathrm{O} / \mathrm{CH}_{3} \mathrm{CN} \\
\text { with dispersed } \\
\text { photocatalysts and } \\
\text { Ru } \\
\text { based photosensitizer }\end{array}$ & 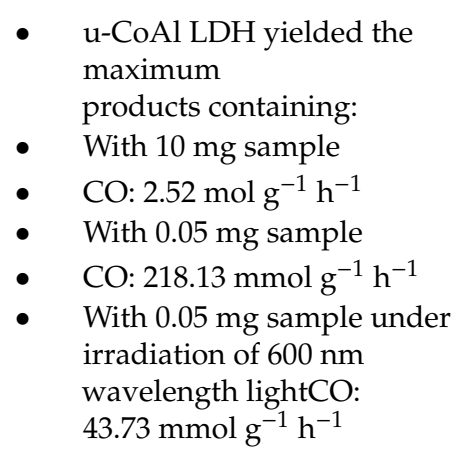 & $\begin{array}{l}\text { - Abundant availability of } \\
\text { vacancies in terms of } V_{o} \text { and } \\
V_{M} \text { enhances the } \\
\text { photocatalytic performance } \\
\text { due to enhanced charge } \\
\text { transport and separation }\end{array}$ & [54] \\
\hline $\begin{array}{l}\text { Zn based LHD, } \\
\text { represented by } \\
\text { ZnM-LDH, where } \mathrm{M} \\
=\mathrm{Ti}, \mathrm{Fe}, \mathrm{Co}, \mathrm{Ga} \text {, and } \\
\mathrm{Al}\end{array}$ & $\begin{array}{l}\text { To investigate the role of } \\
\text { trivalent and tetravalent } \\
\text { metal cations in the } \mathrm{LDH} \\
\text { towards } \mathrm{CO}_{2} \\
\text { photoreduction and } \\
\text { product selectivity }\end{array}$ & $\begin{array}{l}\text { - UV light is obtained } \\
\text { from Xenon lamp of } \\
300 \mathrm{~W} \text { with } \\
\text { wavelength of } \\
400-800 \mathrm{~nm} \\
\text { - The water and } \\
\text { photocatalyst are } \\
\text { spread on the base of } \\
\text { the reaction chamber } \\
\text { and } \mathrm{CO}_{2} \text { gas in } \\
\text { introduced to } \\
\text { the reactor }\end{array}$ & 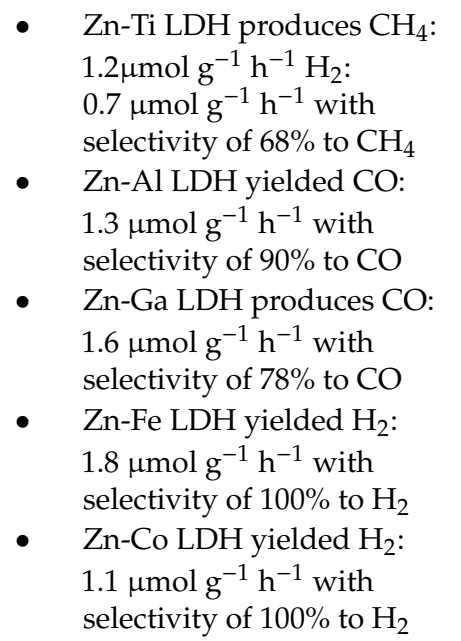 & $\begin{array}{l}\text { - Trivalent and tetravalent } \\
\text { metal cations improved alters } \\
\text { the selectivity of the products } \\
\text { The metal ions with d-band } \\
\text { centers relatively close to } \\
\text { Fermi level strongly adsorb } \\
\text { the } \mathrm{CO}_{2} \text { and produced } \mathrm{CH}_{4} \text { or } \\
\mathrm{CO} \text { dominantly } \\
\text { Whereas the metal ions with } \\
\text { d-band centers far from Fermi } \\
\text { level poorly adsorb the } \mathrm{CO}_{2} \\
\text { and yielded } \mathrm{H}_{2} \text { as a } \\
\text { major product }\end{array}$ & [55] \\
\hline
\end{tabular}


Table 1. Cont.

\begin{tabular}{|c|c|c|c|c|c|}
\hline LDH Photocatalysts & Research Objective & $\begin{array}{l}\text { Light Source and } \\
\text { Reactants Employed }\end{array}$ & $\begin{array}{c}\text { Photocatalytic Activity, } \mathrm{CO}_{2} \\
\text { Conversion to Value Added } \\
\text { Chemicals }\end{array}$ & $\begin{array}{l}\text { Parameters Contributing towards } \\
\text { Improved Performance }\end{array}$ & Ref \\
\hline $\begin{array}{l}\text { NiO Nano sheets } \\
\text { synthesized form } \\
\text { oxidation of } \\
\text { NiAl-LDH }\end{array}$ & $\begin{array}{l}\text { Synthesis approach for } \\
\text { thins } \mathrm{NiO} \text { sheets having } \\
\mathrm{Ni} \text { and } \mathrm{O} \text { vacancies via } \\
\text { oxidation of NiAl-LDH }\end{array}$ & $\begin{array}{l}\text { Light irradiation was } \\
\text { obtained from } 300 \mathrm{~W} \\
\text { Xe lamp } \\
(300-800 \mathrm{~nm}) \\
\text { The reaction } \\
\text { occurred in liquid } \\
\text { phase with } \mathrm{CO}_{2} \\
\text { bubbled through } \\
\text { water/acetonitrile } \\
\text { mixture, Ru based } \\
\text { photosensitizer and } \\
\text { TEOA as a } \\
\text { sacrificial agent }\end{array}$ & $\begin{array}{l}\text { - } \mathrm{NiO} \text { nanosheets produced } \\
\text { at a temperature of } 275^{\circ} \mathrm{C} \text {, } \\
\text { represented by NiAl-275 } \\
\text { showed the maximum } \\
\text { product yield, i.e., } \mathrm{CH}_{4} \text { : } \\
95 \mu \mathrm{mol} \mathrm{g}^{-1} \mathrm{~h}^{-1}\end{array}$ & $\begin{array}{l}\text { - At the optimum temperature, } \\
\text { i.e., } 275{ }^{\circ} \mathrm{C} \text {, a special increase } \\
\text { in the concentration's special } \\
\text { structure with optimized } \\
\text { defects of Ni and oxygen is } \\
\text { achieved, which tunes the } \\
\text { selectivity and performance of } \\
\text { the photocatalyst }\end{array}$ & [56] \\
\hline
\end{tabular}


(a)
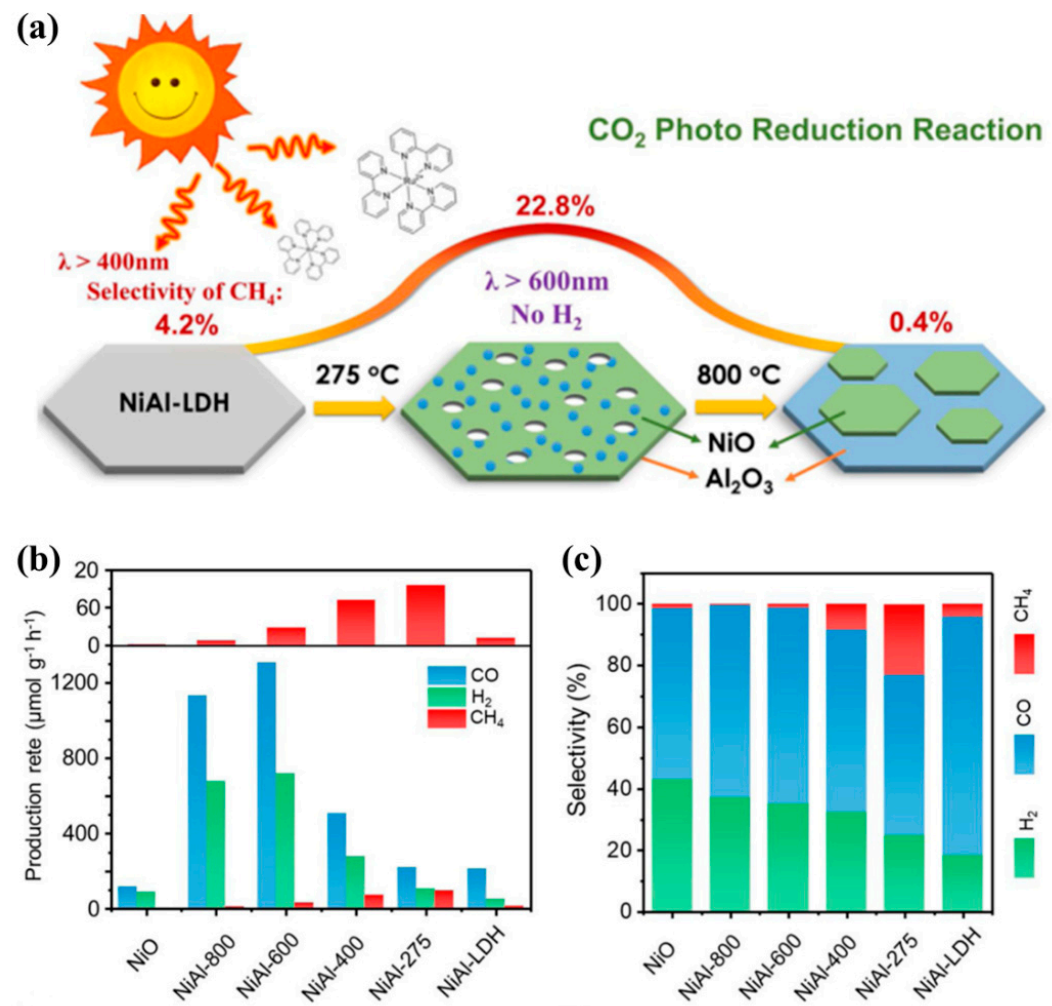

Figure 10. (a) Schematic view of the synthesis approach developed for obtaining $\mathrm{NiO}$ photocatalyst. (b) Photocatalytic $\mathrm{CO}_{2}$ conversion to useful chemicals. (c) Selectivity for various NiAl-LDH photocatalysts, oxidized at various temperatures as represented by temperature value after name. (Figures taken with permission from reference [56]. Copyright 2020, Elsevier).

\section{Metals Loaded/Embedded Layered Double Hydroxide (LDH) Photocatalysts}

Another effective strategy for the development of efficient LDH photocatalysts is to couple, embed, or dope the metals/non-metals to LDH structures, which will lead to improved photocatalytic performance in terms of $\mathrm{CO}_{2}$ photo-reduction. Until today, a limited amount of investigations has been done with respect to mentioned domain; however, there exists an enormous potential to develop metals embedded or doped $\mathrm{LDH}$, which might result in an enhanced and efficient photocatalytic $\mathrm{CO}_{2}$ conversion to useful chemicals/fuels.

Zhao et al. reported a Ti embedded MgAl-LDH (MgAlTi-LDH) synthesized by three different methodologies and their performance evaluated by photocatalytic $\mathrm{CO}_{2}$ conversion with water to useful products [57]. The three different synthesis methodologies include (i) co-precipitation (CP), (ii) co-precipitation and hydrothermal (HT), and (iii) co-precipitation followed by calcination and reconstruction (R). It was observed that the two key factors influencing the photocatalytic activity were crystallinity and surface area of the prepared samples. Moreover, the effect of the temperature treatment was also investigated in accordance with the photocatalytic performance. Figure 11a shows the surface morphologies for the MgAlTi-LDH samples synthesized by coprecicpitation method followed by $\mathrm{HT}$ and R treatment at various temperatures, respectively. It was observed that the CP samples hydrothermally treated at different temperatures go under transformation of their small nanoflakes $(50 \mathrm{~nm})$ to large nanoflakes with increased size $(500-1000 \mathrm{~nm})$. Such transformation indicates the increase of crystallite size, which was also confirmed by XRD data. On the other hand, calcinated and reconstructed samples (R-MgAlTi LDH) do not exhibit any significant change in the crystallite size with the increase of the temperature. When employed for photocatalytic $\mathrm{CO}_{2}$ tests, all samples exhibited better $\mathrm{CO}$ yield as compared to standard $\mathrm{TiO}_{2}-\mathrm{P} 25$. Figure $11 \mathrm{~b}, \mathrm{c}$ show the photocatalytic $\mathrm{CO}_{2}$ conversion to $\mathrm{CO}$ normalized by catalyst mass and surface area, respectively. It was noticed that HT150 and HT200 samples (hydrothermally treated sample at 150 and $200^{\circ} \mathrm{C}$ ) exhibit best performance 
in accordance with both parameters, which can be attributed to the optimum condition of $\mathrm{TiO}_{2}$ crystallinity, crystallite size, band gap, and surface area of the LDH photocatalyst.
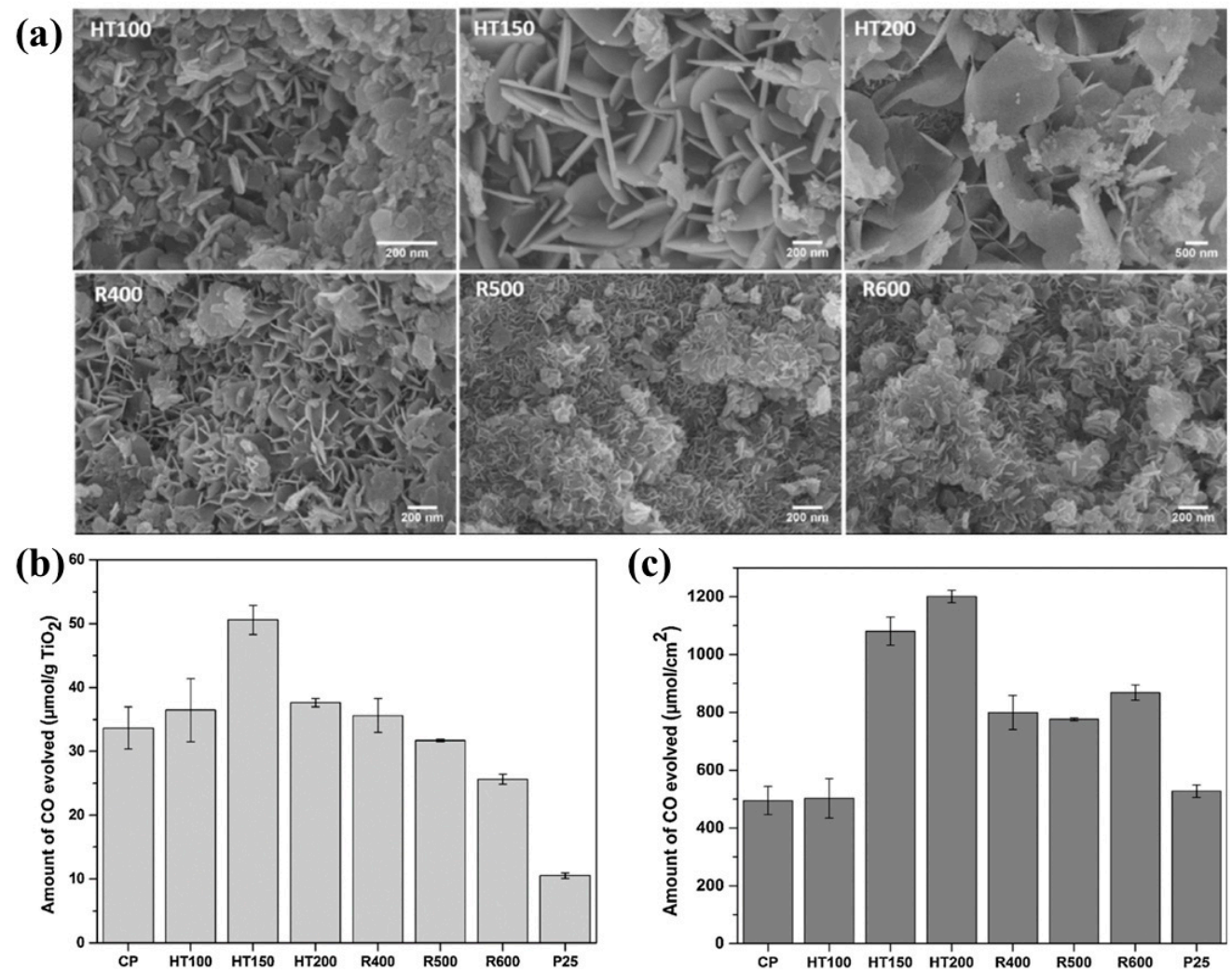

Figure 11. (a) SEM images for the MgAlTi-LDH samples synthesized by coprecipitation approach followed by hydrothermal treatment (HT100, HT150, and HT200) and coprecipitation followed by calcination and reconstruction (R400, R500, and R600); the number represents the temperature value. (b) Photocatalytic $\mathrm{CO}$ production rate normalized as amount of $\mathrm{TiO}_{2}$ present in the $\mathrm{LDH}$ photocatalysts and (c) normalized per surface area of the LDH photocatalysts synthesized. (Figures taken from [57]. Copyright 2016, Elsevier).

A research work reported by Iguchi et al. presented extension of their previously reported work by modifying the $\mathrm{MgAl} \mathrm{LDH}$ with $\mathrm{Ga}_{2} \mathrm{O}_{3}$ and loading $\mathrm{Ag}$ nanoparticles on it [58]. It was observed that by loading $0.25 \mathrm{wt}$ \% of $\mathrm{Ag}$ co-catalyst of $\mathrm{Ga}_{2} \mathrm{O}_{3}-\mathrm{MgAl} \mathrm{LDH}$, the photocatalytic $\mathrm{CO}_{2}$ conversion to $\mathrm{CO}$ was improved with enhanced selectivity towards $\mathrm{CO}$. The molar concentration of already prepared MgAl LDH was varied in order to optimize the sample with the best performance. It was observed the sample with 95 molar concentration and $0.25 \mathrm{wt} \%$ of loaded Ag co-catalyst, exhibited the best performance, yielding $211.7 \mu \mathrm{mol} / \mathrm{h}$ with $0.19 \mathrm{~g}$ of photocatalyst. Such an increased yield was associated to the enhanced $\mathrm{CO}_{2}$ adsorption by $\mathrm{MgAl} \mathrm{LDH}$, improving surface areas and selectivity induced by Ag nanoparticles.

Another research investigated by Chong et al. presents the role of MgAl-LDO as an interlayer in between $\mathrm{Pt}$ and $\mathrm{TiO}_{2}$ for $\mathrm{CO}_{2}$ photo-reduction to useful chemicals [59]. It was observed that the insertion of MgAl-LDO layer boosts the photocatalytic $\mathrm{CO}_{2}$ conversion to $\mathrm{CO}$ and $\mathrm{CH}_{4}$ as compared to reference samples. The authors used rutile $\mathrm{TiO}_{2}$ rods, as they are more active for water oxidation, thus providing more protons and electrons, which can be utilized for $\mathrm{CO}_{2}$ photo-reduction. The $\mathrm{MgAl}-\mathrm{LDH}$ was in situ deposited and then calcined at high temperature to give LDO upon which the Pt (fixed $1 \mathrm{wt}$ \% $)$ was deposited. The sample optimization was performed by varying the loading amount of MgAl-LDH on the $\mathrm{TiO}_{2}$ surface. It was observed that there exist no significant changes in the sample crystallinity, surface morphology, and surface areas. Figure $12 \mathrm{a}-\mathrm{c}$ shows TEM images for the Pt-MgAl-LDO-TiO 2 
photocatalyst with clear depiction of the MgAl-LDO interlayer and Pt deposition. Figure $12 \mathrm{~d}$ shows the photocatalytic $\mathrm{CO}$ and $\mathrm{CH}_{4}$ evolution rate from $\mathrm{CO}_{2}$ photo-reduction and it can be noticed that $\mathrm{Pt}-\mathrm{MgAl}-\mathrm{LDO}-\mathrm{TiO}_{2}$ exhibit the highest production rate as compared to all other samples. The key parameter for promoting and enhancing the photocatalytic $\mathrm{CO}_{2}$ conversion is synergetic effect of $\mathrm{Pt}$ deposition and interlayer of MgAl-LDO. It was proposed that the thin layer of MgAl-LDO optimized by $\mathrm{MgAl}-\mathrm{LDO}$ deposition promotes the $\mathrm{CO}_{2}$ adsorption and efficient transfer of photogenerated electrons to $\mathrm{Pt}$ where the $\mathrm{CO}_{2}$ photo-reduction can occur. Moreover, the Pt nanoparticles act as electron sinks, and once they receive the photoexcited electrons, it is difficult for them to go back and recombine. The proposed reaction mechanism is well displayed in Figure 12e.
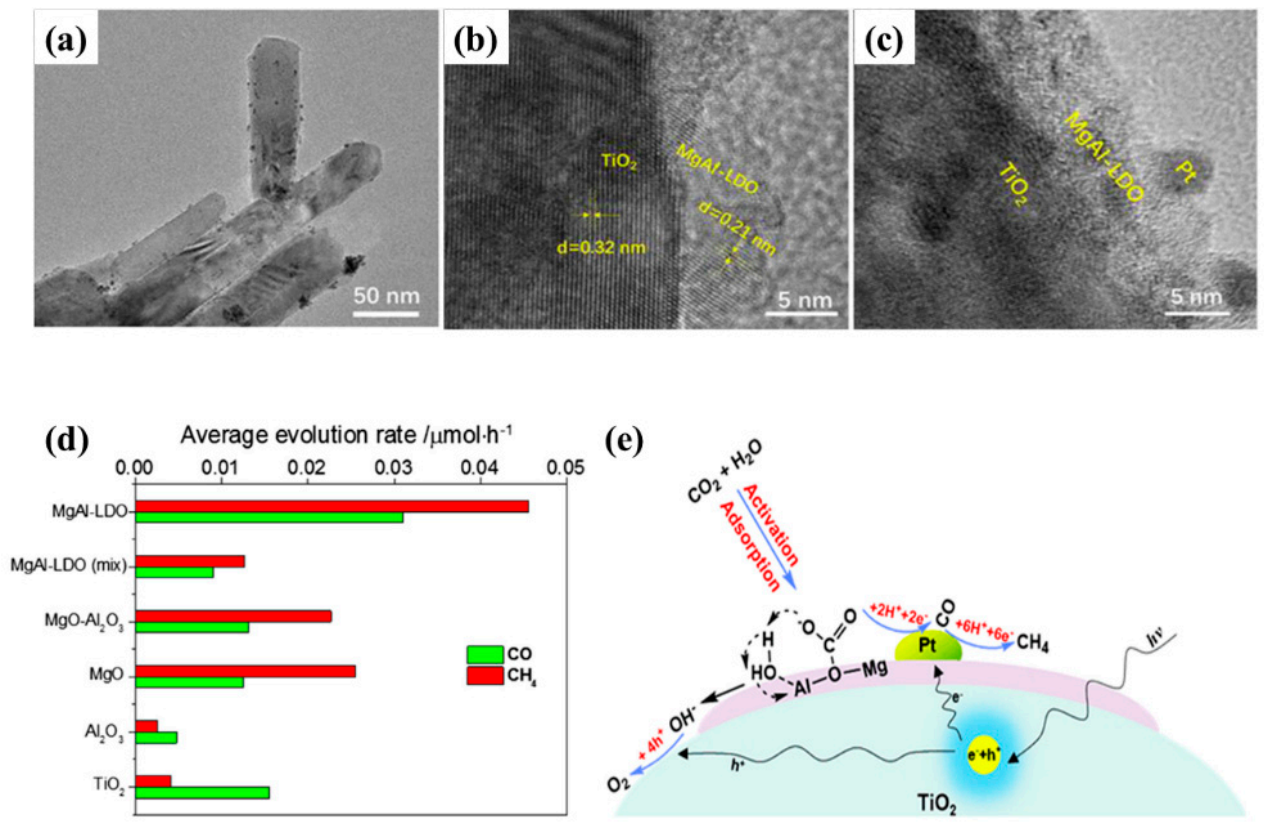

Figure 12. (a-c) TEM images for the Pt-MgAl-LDO- $\mathrm{TiO}_{2}$ indicating the presence of interlayer $\mathrm{MgAl}-\mathrm{LDO}$ between $\mathrm{Pt}$ nanoparticles and rutile $\mathrm{TiO}_{2}$ nanorods. (d) $\mathrm{CO}$ and $\mathrm{CH}_{4}$ evolution rate for all samples synthesized when employed for photocatalytic $\mathrm{CO}_{2}$ conversion. (e) Proposed mechanism involved in the photocatalytic $\mathrm{CO}_{2}$ conversion to $\mathrm{CO}$ and $\mathrm{CH}_{4}$ on the surface of Pt-MgAl-LDO-TiO 2 . (Figures taken from [59]. Copyright 2018, Elsevier).

Another research conducted by Wang et al. developed series of palladium (Pd) loaded CoAl-LDH $(\mathrm{Pd} / \mathrm{CoAl}-\mathrm{LDH})$ photocatalysts with varied content of $\mathrm{Pd}$, in combination with a ruthenium-based complex acting as a photosensitizer [60]. When these photocatalysts employed for photocatalytic $\mathrm{CO}_{2}$ conversion, the syngas $\mathrm{CO} / \mathrm{H}_{2}$ was the major product, where Pd promotes the production of $\mathrm{H}_{2}$ and CoAl-LDH yielded $\mathrm{CO}$ under visible light irradiation even when extended above $600 \mathrm{~nm}$. It was observed that the ratio of $\mathrm{CO} / \mathrm{H}_{2}$ can be tuned by varying the loading of $\mathrm{Pd}$ nanoparticles. Figure $13 \mathrm{a}, \mathrm{b}$ show the production rate of $\mathrm{CO} / \mathrm{H}_{2}$ and selectivity with varying the ratio of $\mathrm{Pd}$. It can be noticed that with increasing the $\mathrm{Pd}$ amount, the relative amount of $\mathrm{H}_{2}$ is increased due to reduction of protons. As $\mathrm{Pd}$ is a well-known $\mathrm{H}_{2}$ producing cocatalyst, $\mathrm{H}_{2}$ is produced by $\mathrm{Pd}$, which captures the photogenerated electrons from the $\mathrm{LDH}$, whereas the photogenerated electrons within the LDH can directly react with the adsorbed $\mathrm{CO}_{2}$ to convert it into $\mathrm{CO}$. The proposed mechanism of the $\mathrm{CO}_{2}$ photo-reduction over the prepared photocatalysts is shown in Figure $13 \mathrm{c}$ where triethanolamine (TEOA) assists to regenerate the Ru based photosensitizer.

The summarized overview of up to date developed metal embedded/loaded LDH photocatalysts employed for photocatalytic $\mathrm{CO}_{2}$ conversion to useful chemicals are presented in Table 2 in respect to research objective, reaction conditions, products yielded, and important influential parameters contributing to enhanced performance. 
Table 2. Summary of various metal loaded/embedded LDH photocatalysts with research goal, reaction conditions, value added chemicals production by photocatalytic $\mathrm{CO}_{2}$ conversion, and key parameters for improving performance.

\begin{tabular}{|c|c|c|c|c|c|}
\hline $\begin{array}{l}\text { LDH Photo Catalysts + } \\
\text { Composite }\end{array}$ & Research Objective & $\begin{array}{l}\text { Light Source and } \\
\text { Reactants Employed }\end{array}$ & $\begin{array}{c}\text { Photo Catalytic Activity, } \mathrm{CO}_{2} \text { Conversion to } \\
\text { Value Added Chemicals }\end{array}$ & $\begin{array}{l}\text { Parameters Contributing } \\
\text { towards Improved } \\
\text { Performance }\end{array}$ & Ref. \\
\hline $\begin{array}{l}\text { Ti-embedded MgAl LDH } \\
\text { represented as } \\
\text { MgAlTi-LDH }\end{array}$ & $\begin{array}{l}\text { Development of a } \\
\text { ternary LDH } \\
\text { Exploration of three } \\
\text { different synthesis } \\
\text { approaches and } \\
\text { investigation of LDH } \\
\text { photocatalysts for } \\
\mathrm{CO}_{2} \text { photoreduction }\end{array}$ & $\begin{array}{l}\text { - UV-Vis light } \\
\text { Obtained from } 400 \mathrm{~W} \\
\text { Xe lamp providing } \\
\text { light in the range of } \\
200-1000 \mathrm{~nm} . \\
\mathrm{CO}_{2} \text { gas was } \\
\text { bubbled through } \\
\mathrm{H}_{2} \mathrm{O} \text { towards the } \\
\text { reactor for PCC }\end{array}$ & $\begin{array}{l}\text { - Only } \mathrm{CO} \text { was detected as a main product for } \\
\text { all samples with minor } \mathrm{CH}_{4} \\
\text { - The sample which was synthesized by } \\
\text { co-precipitation approach and followed by } \\
\text { hydrothermal treatment at } 150^{\circ} \mathrm{C} \text { showed } \\
\text { the best } \mathrm{CO} \text { yield of } \\
\text { - } \mathrm{CO} 50 \mu \mathrm{mol} \text { for } 5 \mathrm{~h} \text { of irradiation normalized } \\
\text { per g of } \mathrm{TiO}_{2}\end{array}$ & $\begin{array}{l}\text { Band gap, specific } \\
\text { surface area, } \mathrm{TiO}_{2} \\
\text { crystallinity, and } \\
\text { crystallite size; all } \\
\text { these factors } \\
\text { contributed to the } \\
\text { improved } \\
\text { photocatalytic activity }\end{array}$ & [57] \\
\hline Pt-MgAL-LDO-TiO ${ }_{2}$ & $\begin{array}{l}\text { Development of an } \\
\text { efficient LDO } \\
\text { photocatalysts via } \\
\text { introduction of } \\
\mathrm{MgAl} \mathrm{LDO} \mathrm{at} \\
\text { interface of } \mathrm{TiO}_{2} \text { and } \\
\text { Pt nanoparticles }\end{array}$ & $\begin{array}{ll}\text { - } & \text { Light is obtained } \\
\text { from } 300 \mathrm{~W} \\
\text { Xenon lamp } \\
\text { - } \mathrm{CO}_{2} \text { with } \mathrm{H}_{2} \mathrm{O} \text { vapor } \\
\text { were used } \\
\text { as reactants }\end{array}$ & 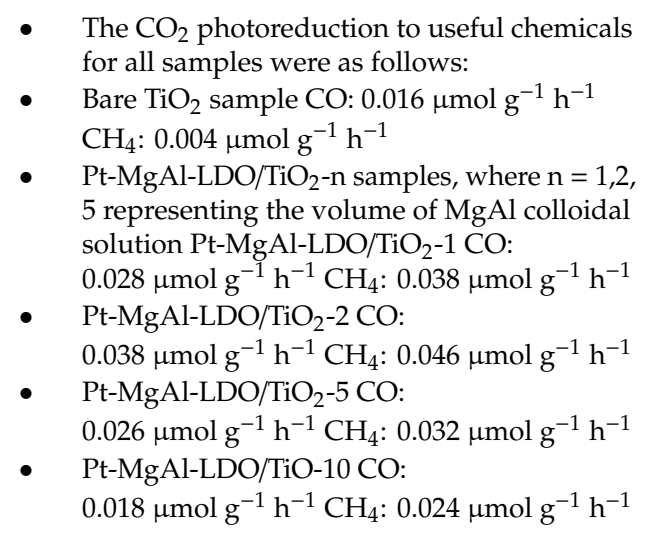 & $\begin{array}{l}\text { Enhanced } \\
\text { adsorption of } \mathrm{CO}_{2} \\
\text { on MgAl-LDH } \\
\text { surface and thus } \\
\text { easiness of its } \\
\text { dissociation with } \\
\mathrm{H}_{2} \mathrm{O} \text { molecules } \\
\text { Efficient } \\
\text { photogenerated } \\
\text { charge separation by } \\
\text { Pt leading to } \\
\text { improved } \\
\mathrm{CO}_{2} \text { photoreduction }\end{array}$ & [59] \\
\hline
\end{tabular}


Table 2. Cont.

\begin{tabular}{|c|c|c|c|c|c|}
\hline $\begin{array}{l}\text { LDH Photo Catalysts + } \\
\text { Composite }\end{array}$ & Research Objective & $\begin{array}{l}\text { Light Source and } \\
\text { Reactants Employed }\end{array}$ & $\begin{array}{c}\text { Photo Catalytic Activity, } \mathrm{CO}_{2} \text { Conversion to } \\
\text { Value Added Chemicals }\end{array}$ & $\begin{array}{l}\text { Parameters Contributing } \\
\text { towards Improved } \\
\text { Performance }\end{array}$ & Ref. \\
\hline $\begin{array}{l}\mathrm{Pd} / \mathrm{CoAl}-\mathrm{LDH} \text { and } \mathrm{Ru} \\
\text { based photosensitizer }\end{array}$ & $\begin{array}{l}\text { Development of an } \\
\text { efficient } \\
\text { heterostructure for } \\
\text { photocatalytic } \mathrm{CO}_{2} \\
\text { conversion to syngas } \\
\text { under } \\
\text { light irradiation }\end{array}$ & $\begin{array}{l}\mathrm{CO}_{2} \text { reduction } \\
\text { carried out under } \\
\text { visible light } \\
\text { irradiation with } \\
\text { wavelength more } \\
\text { than } 400 \mathrm{~nm} \text { and in } \\
\text { gaseous phase }\end{array}$ & $\begin{array}{l}\text { - } \mathrm{Pd} / \mathrm{CoAl}-\mathrm{LDH} \text { and } \mathrm{Ru} \text { based photosensitizer } \\
\text { increase the tunable syngas }\left(\mathrm{CO} / \mathrm{H}_{2}\right) \text { molar } \\
\text { ratio from 1:0.74 to } 1: 3 \text { under visible } \\
\text { light irradiation }\end{array}$ & $\begin{array}{l}\text { The presence of Pd } \\
\text { NPs lead to well } \\
\text { adsorb the water } \\
\text { molecules which } \\
\text { lead to formation of } \\
\mathrm{H}_{2} \text { during light } \\
\text { irradiation thus } \\
\text { providing a pathway } \\
\text { to tune the CO to } \\
\mathrm{H}_{2} \text { ratio }\end{array}$ & [60] \\
\hline
\end{tabular}


(a)

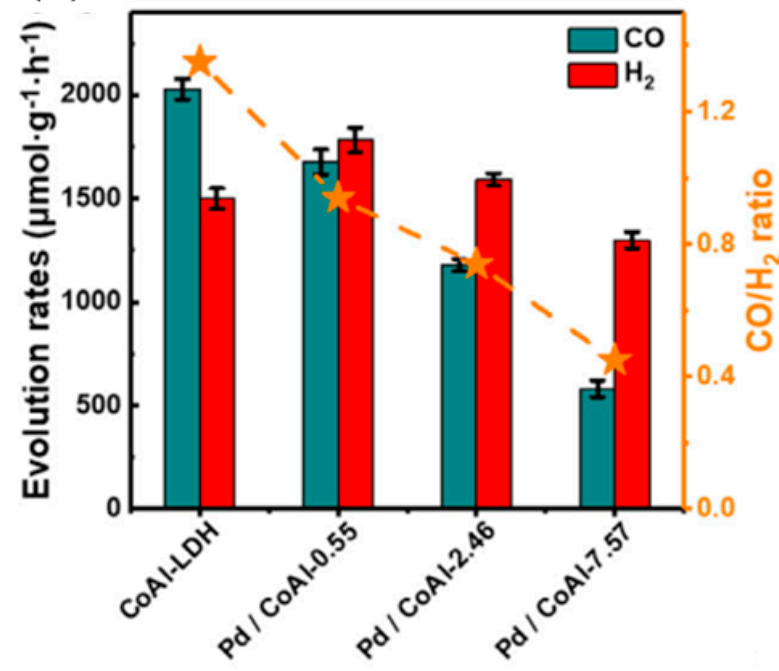

(b)

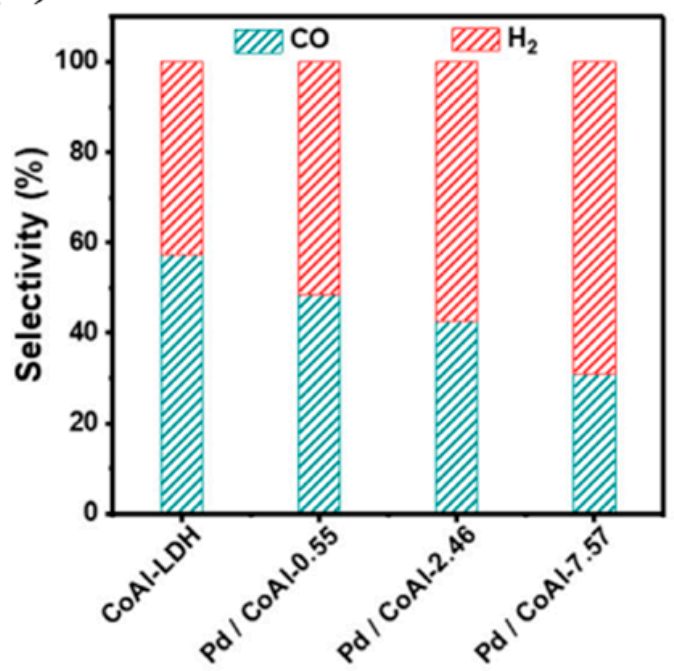

(c)

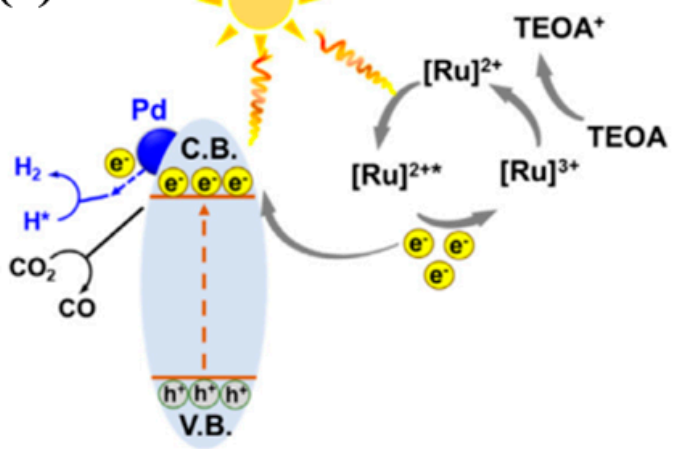

Pd/CoAl-LDH

Figure 13. (a) Photocatalytic evolution syngas via $\mathrm{CO}_{2}$ photo-reduction for varied amount Pd loaded CoAl-LDH (Pd/CoAl-LDH) photocatalysts. (b) Selectivity of prepared LDH photocatalysts towards CO and $\mathrm{H}_{2}$ production with increased Pd content. (c) Proposed mechanism involved in the photocatalytic $\mathrm{CO}_{2}$ conversion to $\mathrm{CO}$ and $\mathrm{H}_{2}$ on the surface of Pd/CoAl-LDH photocatalyst. (Figures taken from [60]. Copyright 2019, Elsevier).

\section{Composite/Hybrid/Heterojunctioned Layered Double Hydroxide (LDH) Based Photocatalysts}

The fabrication of hybrid/heterojunctioned photocatalyst materials has always been an attractive and fascinating domain for the material scientists/researchers. As a well-explored domain, a similar approach is also implicated for the synthesis of hybrid/heterojunctioned photocatalysts employing LDH as one of the components with another established semiconductor material. The LDH support can act as an adsorbent and/or photocatalyst support to capture/convert $\mathrm{CO}_{2}$ into useful products. Hence, the benefits and gains of the hybrid/heterojunctioned materials can be a harvested for $\mathrm{CO}_{2}$ reduction by designing a suitable LDH based hybrid photocatalysts. With plenty of research space, until now, very limited investigations have been done with the respective concept.

A research work reported by Zhao et al. displays hybrid photocatalysts composed of MgAl-LDO coupled with $\mathrm{TiO}_{2}$ cuboids $\left(\mathrm{MgAl}-\mathrm{LDO} / \mathrm{TiO}_{2}\right.$ ) [61]. The photocatalyst was synthesized by the combined approach of hydrothermal and coprecipitation methodologies, and a series of $\mathrm{MgAl}-\mathrm{LDO} / \mathrm{TiO}_{2}$ was prepared with varied molar ratio of $\mathrm{Mg}+\mathrm{Al}$ to $\mathrm{Ti}$, in order to optimize the photocatalyst with best performance. As the MgAl-LDO are reported to be in micrometer size platelets, it was required to synthesize micrometer size $\mathrm{TiO}_{2}$ which were synthesized in micrometer sized cuboids. Figure $14 \mathrm{a}-\mathrm{f}$ shows the morphology of various $\mathrm{MgAl}-\mathrm{LDO} / \mathrm{TiO}_{2}$ photocatalysts with varied ratio of $\mathrm{Mg}+\mathrm{Al}$. It is 
obvious that $\mathrm{MgAl}-\mathrm{LDO}$ platelets were successfully anchored on the $\mathrm{TiO}_{2}$ cuboids even after calcination and do not change the morphology. Hence, this report is also unique in terms of morphology of the photocatalyst obtained. When employed for $\mathrm{CO}_{2}$ photo-reduction with water vapors under $\mathrm{UV}$ light irradiation, $\mathrm{CO}$ was found to be the main product with small amount of $\mathrm{CH}_{4}$. Figure $14 \mathrm{~g}$ shows the $\mathrm{CO}$ production rate by photocatalytic $\mathrm{CO}_{2}$ conversion. It was observed that at a condition of UV light irradiation ( $4 \mathrm{~h}$ ) and $50{ }^{\circ} \mathrm{C}, \mathrm{MgAl}-\mathrm{LDO}$ alone had no activity, and also, when coupled with the $\mathrm{TiO}_{2}$, it did not show any significant photocatalytic activity towards $\mathrm{CO}_{2}$ conversion to $\mathrm{CO}$. This might be due to weak $\mathrm{CO}_{2}$ adsorption at lower temperatures by MgAl-LDO. However, at higher temperature, i.e., $150{ }^{\circ} \mathrm{C}$, the $10 \% \mathrm{Mg}$ - $\mathrm{Al} \mathrm{LDO} / \mathrm{TiO}_{2}$ showed a 5 times higher $\mathrm{CO}$ production as compared to bare $\mathrm{TiO}_{2}$ cuboids. Moreover, $10 \% \mathrm{MgAl}-\mathrm{LDO} / \mathrm{TiO}_{2}$ also exhibited the best performance, hence optimizing the $\mathrm{Mg}+\mathrm{Al}$ ratio to Ti. Such an enhanced $\mathrm{CO}$ production can be attributed to the improved adsorption capacity of MgAl-LDO at higher temperatures. Upon illumination, the photogenerated electron in $\mathrm{TiO}_{2}$ can easily transfer to the nearby interface of $\mathrm{MgAl}-\mathrm{LDO}$ and $\mathrm{TiO}_{2}$, where it can react with adsorbed $\mathrm{CO}_{2}$ converting it into $\mathrm{CO}$. Figure $14 \mathrm{~h}$ shows control tests of $10 \% \mathrm{MgAl}-\mathrm{LDO} / \mathrm{TiO}_{2}$ under He gas and water vapors as reactants. It was observed that, at a temperature of $50{ }^{\circ} \mathrm{C}, 10 \% \mathrm{MgAl}-\mathrm{LDO} / \mathrm{TiO}_{2}$ does not show any $\mathrm{CO}$ yield; however, at a temperature of $150^{\circ} \mathrm{C}$, a considerable amount of $\mathrm{CO}$ was observed. It was proposed that such $\mathrm{CO}$ might be a result of carbonate species on the surface of photocatalyst, which was stable at lower temperature, but at higher temperature, it was converted into CO.

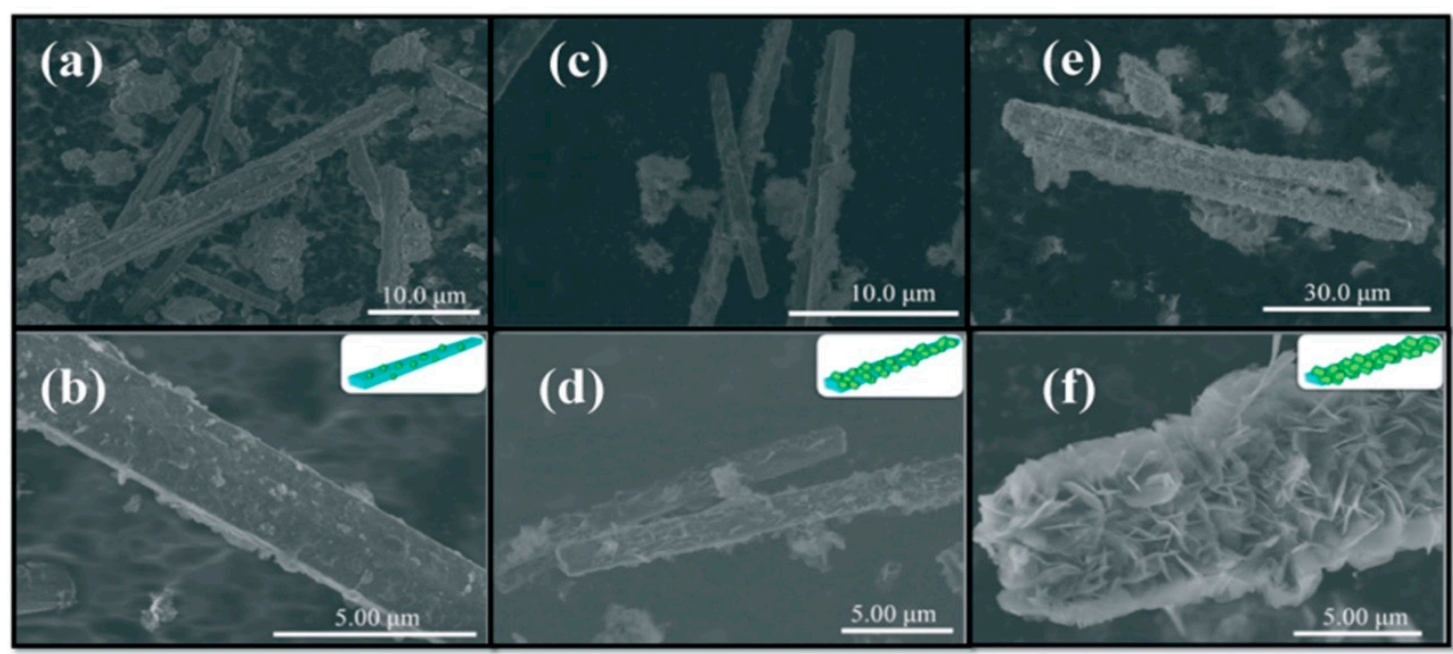

(g)

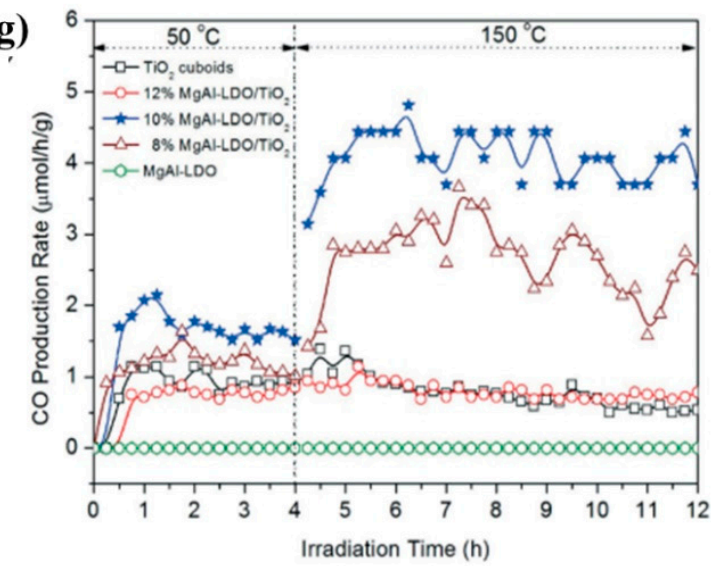

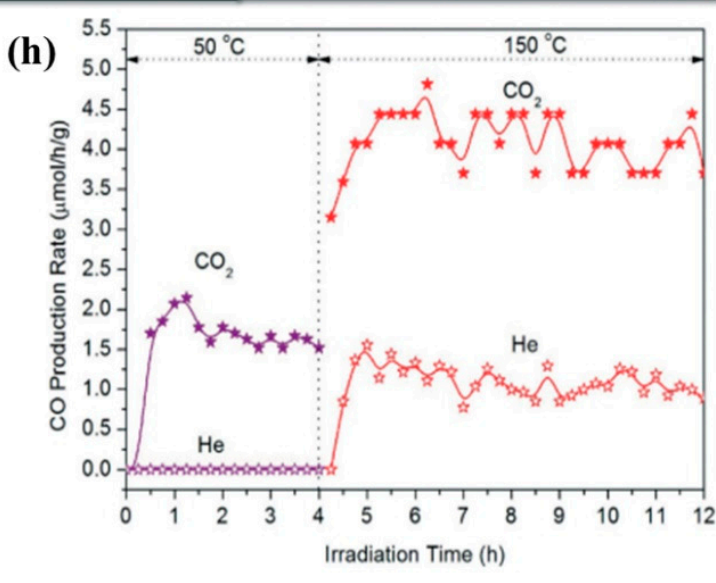

Figure 14. SEM images of $\mathrm{MgAl}-\mathrm{LDO} / \mathrm{TiO}_{2}$ composites: (a,b) $8 \% \mathrm{MgAl}-\mathrm{LDO} / \mathrm{TiO}_{2}$, (c,d) $10 \%$ $\mathrm{MgAl}-\mathrm{LDO} / \mathrm{TiO}_{2}$, and (e,f) $12 \mathrm{wt} . \% \mathrm{MgAl}-\mathrm{LDO} / \mathrm{TiO}_{2}$. Photocatalytic $\mathrm{CO}_{2}$ conversion into CO employing (g) all samples at varied temperature, and (h) 10 wt. $\% \mathrm{MgAl}-\mathrm{LDO} / \mathrm{TiO}_{2}$ under $\mathrm{CO}_{2}+\mathrm{H}_{2} \mathrm{O}$ and $\mathrm{He}+\mathrm{H}_{2} \mathrm{O}$ gaseous composition. (Figures taken with permission from reference [61]. Copyrights 2015, The Royal Society of Chemistry). 
Another work performed by Kumar et al. investigated the heterojunction of CoAl-LDH with P25, a well-known standard $\mathrm{TiO}_{2}$ [62]. P25 nanoparticles were encapsulated within microporous CoAl-LDH by a simple one step hydrothermal approach. It was observed that light absorption of the composite CoAl-LDH -P25 was red shifted, thus capturing the solar spectrum which might lead to improved photocatalytic activity. Furthermore, the $\mathrm{CO}_{2}$ adsorption capacity and matched band alignment also promote the efficient conversion of $\mathrm{CO}_{2}$ into useful chemicals. Figure $15 \mathrm{a}, \mathrm{b}$ shows the morphology of the P25@CoAl-LDH photocatalyst with clear depiction of 2D platelets of CoAl LDH with thickness of approximately $20 \mathrm{~nm}$ and irregular nanoparticles of P25 within size range of 20-50 nm. Figure 15c shows the UV-Vis DRS for all the samples investigated in the research work. P25 showed its characteristic absorption in the UV range with the absorption peak centered around $300 \mathrm{~nm}$, whereas CoAl-LDH exhibited two absorption peaks appearing in the UV and visible range, respectively. The absorption peak appearing around $500 \mathrm{~nm}$ was attributed to the $\mathrm{d}-\mathrm{d}$ transitions of octahedral $\mathrm{Co}^{2+}$. Figure $15 \mathrm{~d}$ shows the steady state photoluminescence (PL) spectroscopy for the samples. The PL peaks for P25@CoAl-LDH were intermediate between pure P25 and CoAl-LDH, thus endorsing the reduced charge recombination within the composite P25@CoAl-LDH photocatalyst. When employed for photocatalytic $\mathrm{CO}_{2}$ conversion, only three products were formed, i.e., $\mathrm{CO}, \mathrm{H}_{2}$, and $\mathrm{O}_{2}$, shown in Figure 16a-d. Pure P25 showed the poorest activity with negligible production; however, CoAl-LDH exhibited certain amount of $\mathrm{CO}$ and $\mathrm{O}_{2}$ production. P25@CoAl-LDH showed a production in between P25 and CoAl-LDH, whereas 20 wt.\% P25@CoAl-LDH showed a superior production of $\mathrm{CO}$ with negligible amount of $\mathrm{CH}_{4}$. Such an increased $\mathrm{CO}$ production and higher selectivity can be attributed to the well heterojunction formation within P25@CoAl-LDH and was associated to extended light absorption, enhanced $\mathrm{CO}_{2}$ adsorption, and effective photogenerated charges separation. Furthermore, the P25@CoAl-LDH sample also exhibited a stable performance up to 3 cycles of $\mathrm{CO}_{2}$ photo-reduction. Figure 15e shows the band gap alignment and heterojunction formation for the P25@CoAl-LDH photocatalyst. As well established, band gap of P25 is suitable for proton reduction but not suitable for $\mathrm{CO}_{2}$ photo-reduction. On the contrary, the bandgap of CoAl-LDH with its conduction band edge at $-0.75 \mathrm{eV}$ can easily produce $\mathrm{CO}$. Thus, the combination of both P25 and CoAl-LDH leads to formation of $\mathrm{p}-\mathrm{n}$ junction which is well aligned for the efficient production of $\mathrm{CO}$ and photogenerated charge separation, ultimately resulting in enhanced photocatalytic activity for $\mathrm{CO}_{2}$ conversion into useful product.

A research work executed by Tang et al. demonstrated the synthesis of unique homo-heterojunction of $\mathrm{BiOCl}$ nanoplates coupled with $\mathrm{ZnCr}$-LDH by a simple electrostatic interaction method [63]. As well-known BiOCl generally consists of two directions, that is, $\{001\}$ and $\{110\}$ surfaces. Both surfaces form a homojunction within the $\mathrm{BiOCl}$, whereas the $\mathrm{ZnCr}-\mathrm{LDH}$ can assemble on $\{001\}$ surface via electrostatic interaction. A built-in field will allow the electrons generated under irradiation to flow from one facet to another facet of $\mathrm{BiOCl}$, from where they can easily flow down to the coupled $\mathrm{ZnCr}-\mathrm{LDH}$ and react with adsorbed $\mathrm{CO}_{2}$. Various samples were synthesized with different content of the $\mathrm{ZnCr}-\mathrm{LDH}$ represented by "Sc" wt.\%. Figure 17a shows the photocatalytic $\mathrm{CO}_{2}$ conversion for various BiOCl-ZnCr-LDH samples with different contents of $\mathrm{ZnCr}$ yielding $\mathrm{CH}_{4}$ as a main product. The maximum yield was obtained when $\mathrm{ZnCr}-\mathrm{LDH}$ amount was $10 \mathrm{wt} . \%$. The proposed mechanism for charge transfer within BiOCl homojunction and heterojunction with $\mathrm{ZnCr}-\mathrm{LDH}$ is shown in Figure $17 \mathrm{~b}$. The key factor indulged in the performance improvement was the efficient charge transfer.

Another research work executed by Yang and coauthors proposed an urchinlike Z-scheme photocatalyst by hierarchical structure of CoZnAl-LDH/RGO/g- $\mathrm{C}_{3} \mathrm{~N}_{4}$ (LDH/RGO/CN) [64]. The LDH was synthesized by simple hydrothermal method, while for the synthesis of $\mathrm{LDH} / \mathrm{RGO} / \mathrm{CN}$, the already prepared RGO and $\mathrm{CN}$ were added into the ionic precursors of $\mathrm{LDH}$ and then subjected for hydrothermal process. For the sake of optimization and achieving of best sample, the weight ratio of $\mathrm{CN}$ was varied among the $\mathrm{LDH} / \mathrm{RGO} / \mathrm{CN}$ hybrid photocatalyst. The schematic view of the synthesis procedure designed to achieve LDH/RGO/CN is shown in Figure 18a. The morphologies of CN and LDH/RGO/CN 
are shown in Figure $18 \mathrm{~b}, \mathrm{c}$, respectively. The $\mathrm{CN}$ exhibited a bulky morphology with somewhat lamellar structures, whereas LDH/RGO/CN exhibited a well observable urchin like nanostructure. When employed for photocatalytic $\mathrm{CO}_{2}$ conversion, $\mathrm{CO}$ was observed as the key product, with $\mathrm{CH}_{4}$ up to $5 \mathrm{~h}$ of irradiation; it is shown in Figure 18d,e. It could be noticed that insertion of RGO between CoZnAl-LDH and CN significantly enhanced the CO yield, specifically for sample LDH/RGO/CN-2 (with $0.1 \mathrm{~g}$ of $\mathrm{CN}$ in the composite) whose $\mathrm{CO}$ yield was 3.4 and 8.5 times higher than $\mathrm{LDH} / \mathrm{CN}$ and bare $\mathrm{CN}$, respectively. As well established, $\mathrm{CO}_{2}$ adsorption and photocatalytic activity are two prime contributors for efficient photocatalytic $\mathrm{CO}_{2}$ conversion. The ternary composite of CoZnAl-LDH shows improved $\mathrm{CO}_{2}$ adsorption whereas $\mathrm{CN}$ is well known for its visible light activity. In addition, the insertion of RGO promotes the efficient charge separation from CoZnAl-LDH to valence band of $\mathrm{CN}$, whereas the holes of CoZnAl-LDH are generated by water oxidation. The proposed schematic based on several analysis techniques is displayed in Figure 18f.
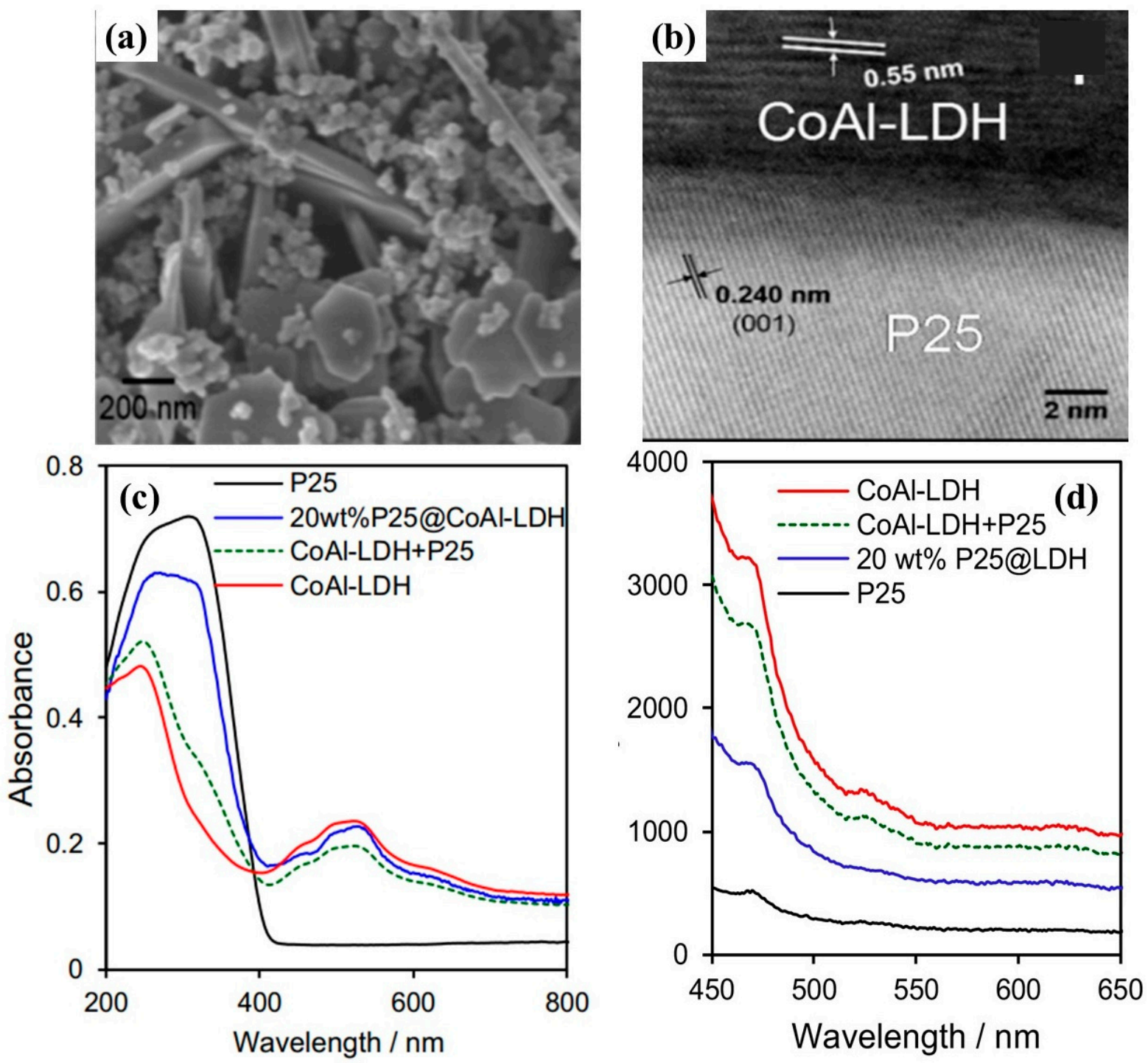

Figure 15. (a) High resolution SEM image and (b) TEM image of 20 wt.\% P25@CoAl-LDH. (c) UV-Vis DRS and (d) PL spectra for all the samples employed in the research. (Figures taken with permission from reference [62]. Copyright 1969, Elsevier). 
(a)
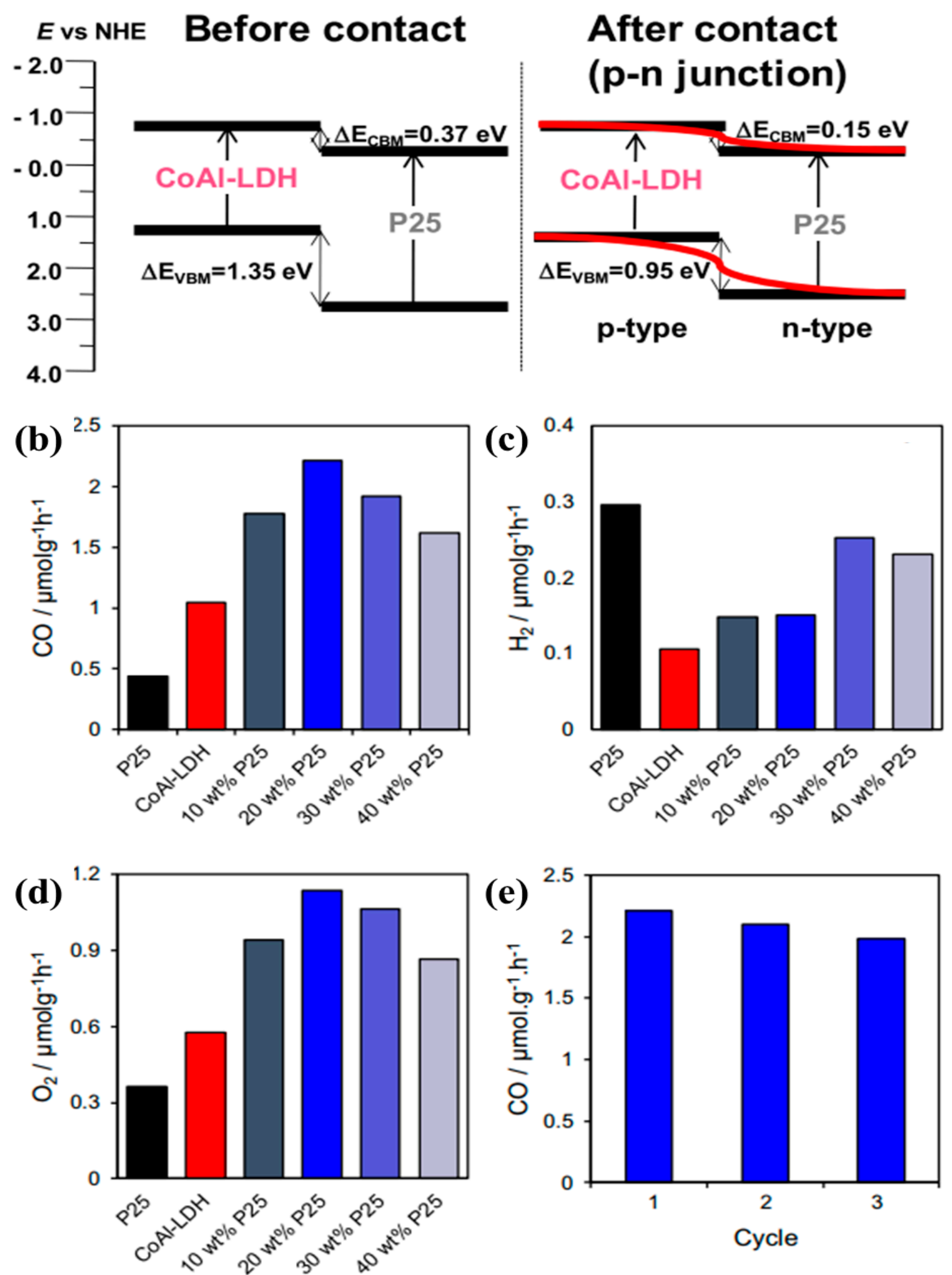

Figure 16. (a) Schematic diagram of the heterojunction formation between P25 and CoAl-LDH. Photocatalytic $\mathrm{CO}_{2}$ conversion to (b) $\mathrm{CO},(\mathbf{c}) \mathrm{H}_{2}$, (d) $\mathrm{O}_{2}$, and (e) stability evaluation for 20 wt.\% P25@CoAl-LDH. (Figures taken with permission from reference [62]. Copyright 1969, Elsevier). 


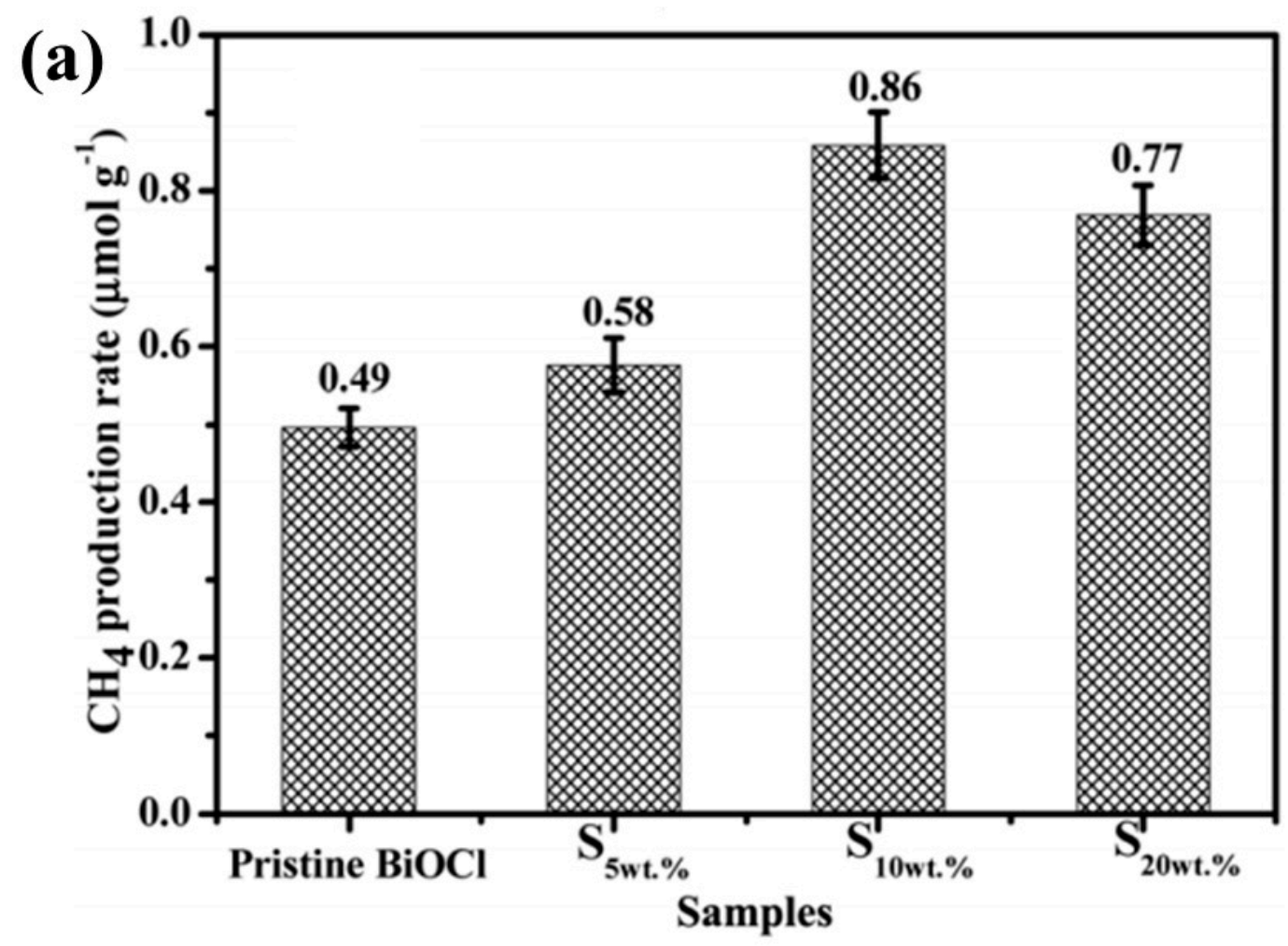

(b)

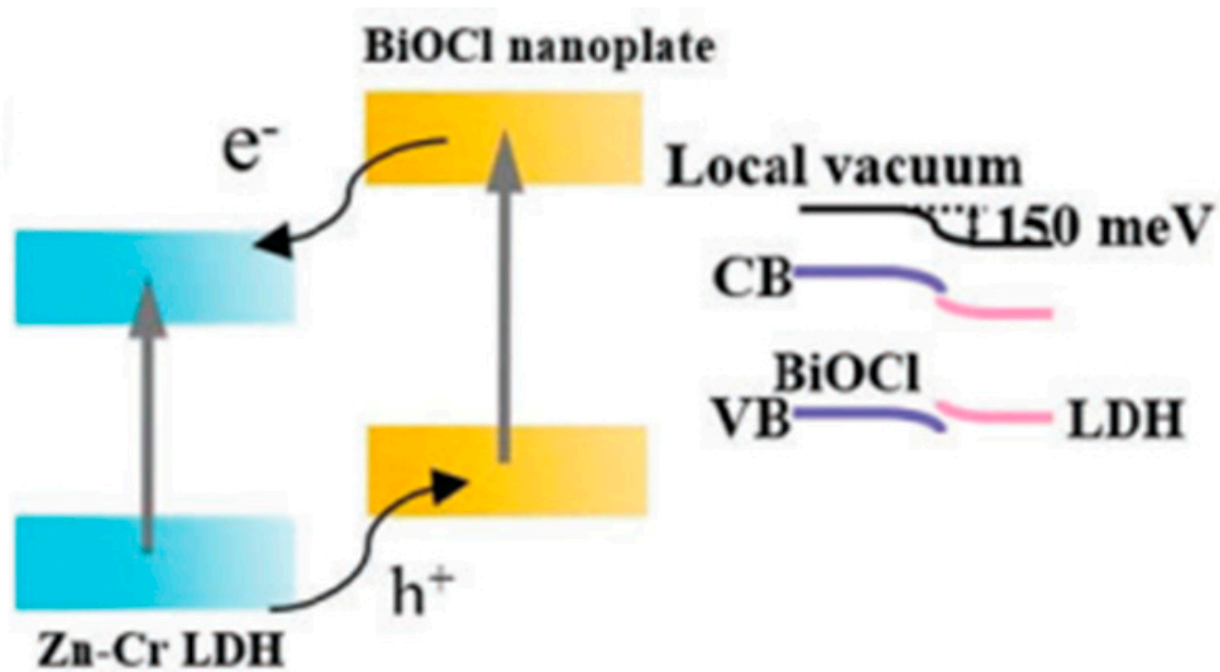

Figure 17. (a) Photocatalytic $\mathrm{CO}_{2}$ conversion to $\mathrm{CH}_{4}$ for various hybrid $\mathrm{BiOCl}-\mathrm{ZnCr}-\mathrm{LDH}$ photocatalysts, $\mathrm{S}$ represents the $\mathrm{BiOCl}-\mathrm{ZnCr}-\mathrm{LDH}$ sample with subscript indicating the composition of the $\mathrm{ZnCr}-\mathrm{LDH}$. (b) Schematic diagram of the heterojunction formation between $\mathrm{BiOCl}$ and $\mathrm{ZnCr} \mathrm{LDH}$. (Figures taken with permission from reference [63]. Copyrights 2018, The Royal Society of Chemistry).

Another excellent work done by Ziarati et al. reported an efficient architecture of 3D yolk@shell $\mathrm{TiO}_{2-x} / \mathrm{CoAl} \mathrm{LDH}\left(\mathrm{Y} @ S \mathrm{TiO}_{2-x} / \mathrm{LDH}\right.$ ) for photocatalytic $\mathrm{CO}_{2}$ conversion to solar fuels [65]. Such an architecture was synthesized by sequential designing of solvothermal, hydrogen treatment, and hydrothermal steps. When such a 3D architecture was employed for $\mathrm{CO}_{2}$ photo-reduction, it yielded $\mathrm{CH}_{3} \mathrm{OH}$ as a main product for the first $2 \mathrm{~h}$ of irradiation; however, the $\mathrm{CH}_{3} \mathrm{OH}$ production decreased with the passage of time, and $\mathrm{CH}_{4}$ yield increased. Figure 19a shows the $\mathrm{CH}_{3} \mathrm{OH}$ production for the 3D architecture photocatalyst along with other reference samples. Figure $19 \mathrm{~b}$ exhibits the time dependent photocatalytic $\mathrm{CO}_{2}$ conversion to solar fuels. Such a conversion of product from $\mathrm{CH}_{3} \mathrm{OH}$ to $\mathrm{CH}_{4}$ is proposed, since, with the passage of time, $\mathrm{CH}_{3} \mathrm{OH}$ gets adsorbed on the surface, 
and photocatalytic is converted into $\mathrm{CH}_{3}$ radical, which reacts with electron and protons to form $\mathrm{CH}_{4}$ as the key product. The enhanced performance of the 3D photocatalyst was attributed to the combination of better $\mathrm{CO}_{2}$ sorption capacity, improved light absorption, and enhanced charge separation at interface of $\mathrm{TiO}_{2-x}$ and $\mathrm{LDH}$.
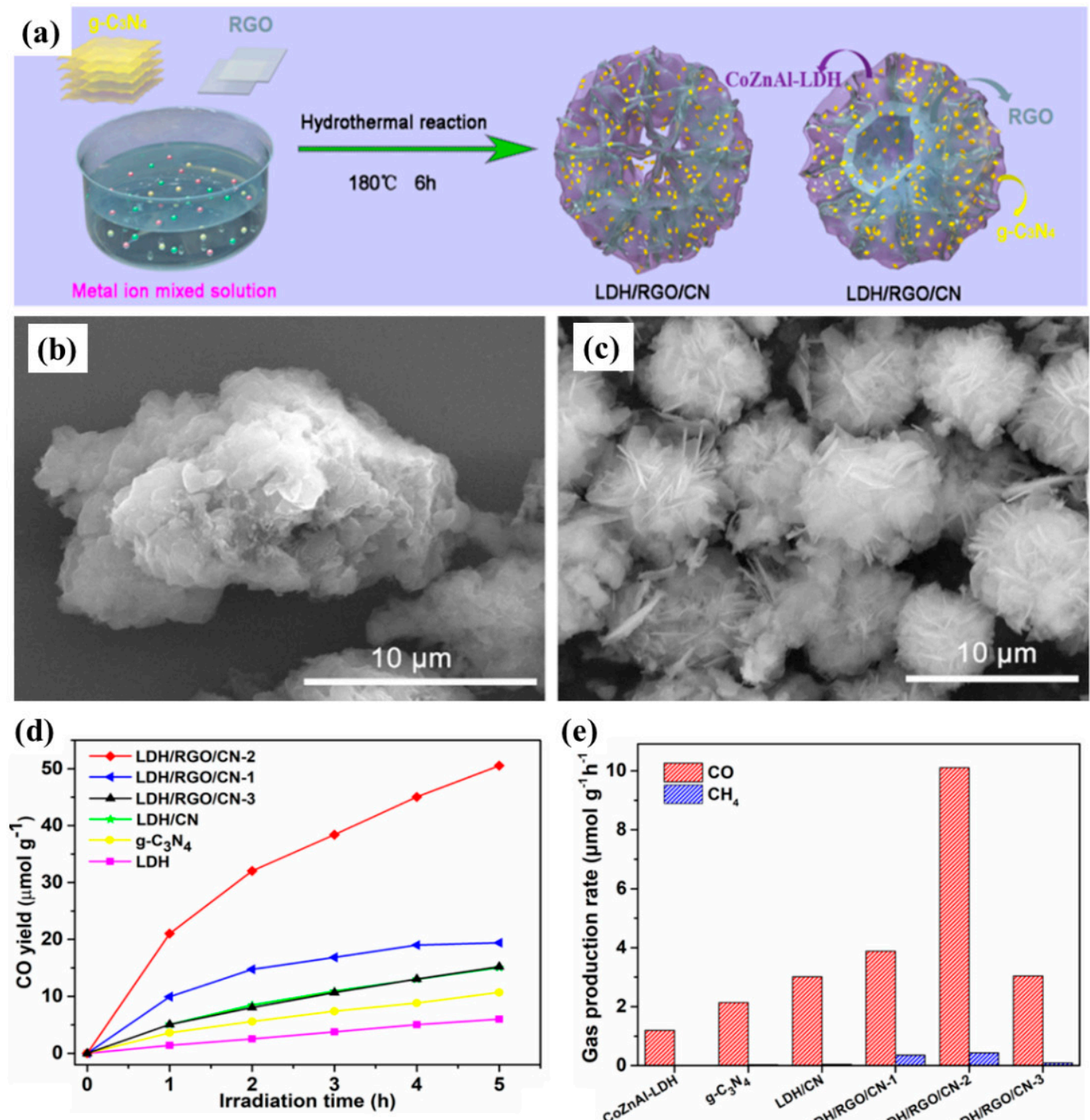

(e)
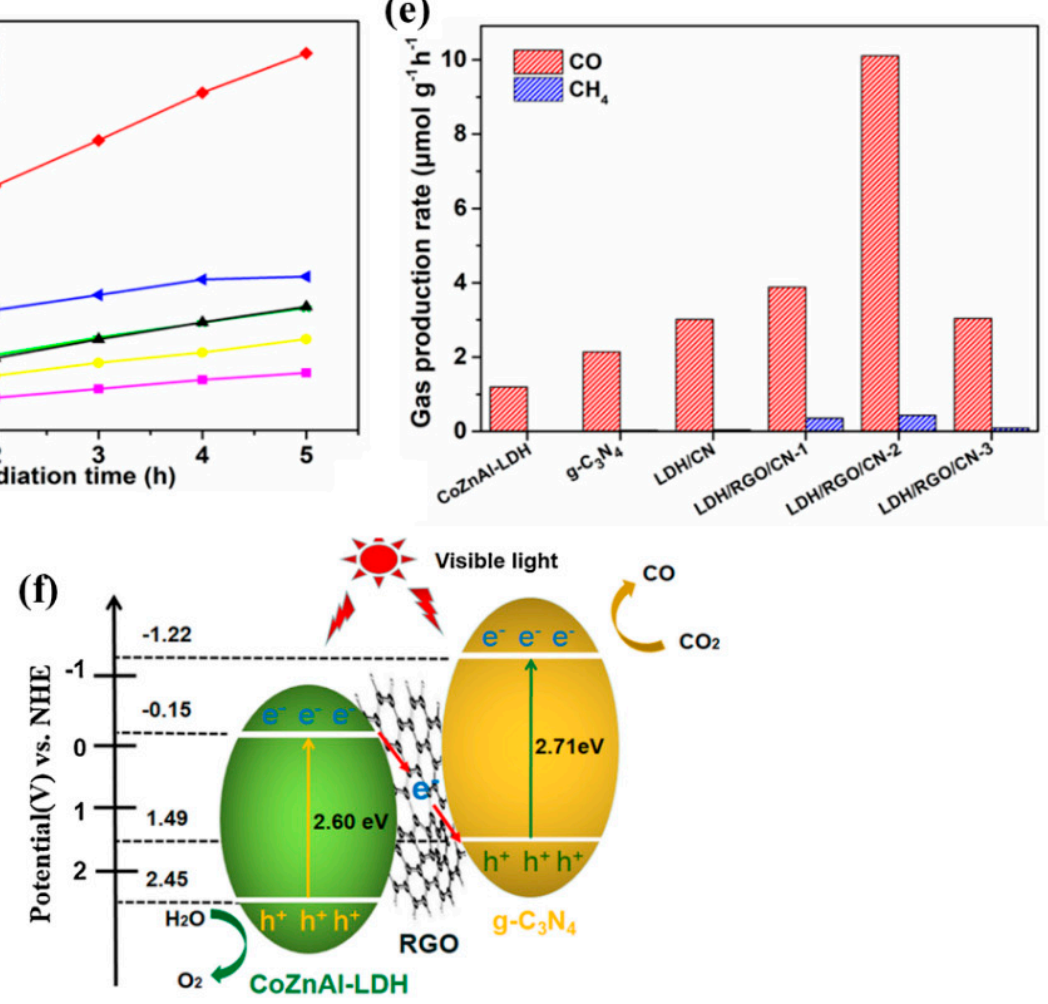

Figure 18. (a) Synthesis scheme of hybrid urchin like LDH/RGO/CN photocatalyst. SEM Images of (b) graphitic carbon nitride $(\mathrm{CN})$, and (c) urchin-like CoZnAl-LDH. (d) Photocatalytic $\mathrm{CO}_{2}$ conversion to $\mathrm{CO}$ for all samples. (e) Production rate of $\mathrm{CO}$ and minor $\mathrm{CH}_{4}$ per hour from all samples. (f) Proposed mechanism for the heterojunctioned formation and photocatalytic $\mathrm{CO}_{2}$ conversion to $\mathrm{CO}$, mainly. (Figures taken with permission from reference [64]. Copyright 2019, Elsevier). 
(a)

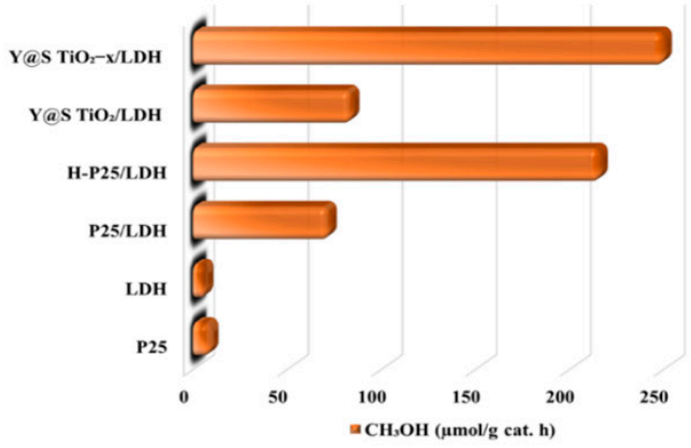

(b)

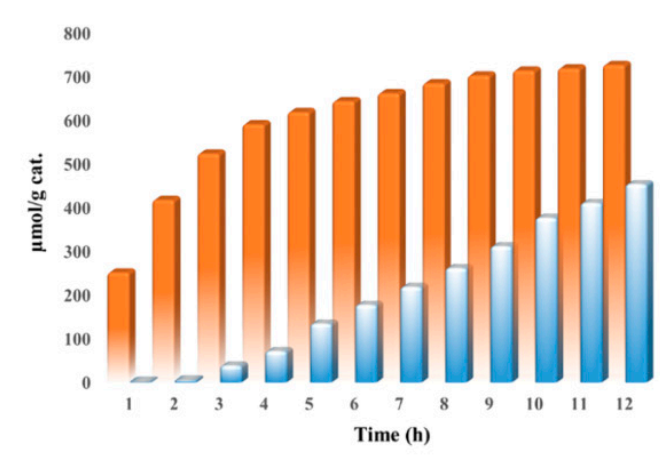

Figure 19. (a) Photocatalytic $\mathrm{CO}_{2}$ conversion into $\mathrm{CH}_{3} \mathrm{OH}$ (various samples). (b) Production rate of $\mathrm{CH}_{3} \mathrm{OH}$ and $\mathrm{CH}_{4}$ as a function of time over the hybrid $\mathrm{LDH}$ based photocatalyst. (Figures taken with permission from reference [65]. Copyright 2019 American Chemical Society).

Another approach represented an LDH based composite photocatalyst with doped strategy. Jo et al. developed a $\mathrm{N}$ doped $\mathrm{C}$ dots/ $\mathrm{CoAl} \mathrm{LDH} / \mathrm{gC}_{3} \mathrm{~N}_{4}(\mathrm{NCD} / \mathrm{LDH} / \mathrm{CN}$, represented as NLC) hybrid photocatalyst with efficient and selective photocatalytic $\mathrm{CO}_{2}$ conversion to $\mathrm{CH}_{4}$ [66]. The $\mathrm{N}$ doped carbon dots (NCD) are well researched materials as an alternate to noble metals cocatalysts. In their work, co-authors designed a strategy to employ NCD in replacement of noble metals and found a significant increase and selective production of $\mathrm{CH}_{4}$. Various NLC photocatalysts were synthesized by varying the contents of $\mathrm{LDH}$ to $\mathrm{CN}$ as 5, 10, 15, and $20 \mathrm{wt} . \%$, whereas the amount of NCD was kept fixed for all samples, which was $2 \mathrm{wt} . \%$. Figure 20a shows the SEM image of the NLC sample exhibiting a flower like morphology with clear depiction of LDH and CN. Figure 20b shows a high resolution TEM image of NLC with clear presence of all three components, i.e., LDH, CN, and NCD in the hybrid sample. When utilized for photocatalytic $\mathrm{CO}_{2}$ conversion, the key product obtained was $\mathrm{CH}_{4}$ with small amounts of $\mathrm{CO}$ and $\mathrm{H}_{2}$, as shown in Figure 20c. It was observed when NLC is formed by $2 \mathrm{wt} . \%$ NCD and with LDH to CN ratio of 10, the sample NLC-10 exhibited the maximum production rate as compared to all other samples. The most remarkable selectivity was $99 \%$ towards $\mathrm{CH}_{4}$ for NLC-10 sample. The reusability of the NLC-10 was also evaluated (shown in Figure 20d), which displayed a durable performance in each cycle, thus representing the stable performance during the prolonged reaction possibly to a good structural stability of the photocatalyst. The prime factors contributing to significantly improved photocatalytic performance of NLC consist of broadened light absorption, optimized surface area, and improved charge separation due to 2D junction in between LDH and CN. Moreover, the product selectivity was attributed to the well aligned band gap with corresponding product redox potential. The proposed mechanism for the photocatalytic $\mathrm{CO}_{2}$ conversion employing NLC-10 sample is shown in Figure 20e. Under the visible light irradiation, both LDH and CN photogenerate the charges and electron flowing down to conduction band of LDH whereas holes from $\mathrm{LDH}$ towards the valence band of $\mathrm{CN}$ where they are regenerated by water oxidation. Due to formation of well-defined 2D-2D heterojunction between $\mathrm{LDH}$ and $\mathrm{CN}$, the photogenerated charges are efficiently transferred and react with $\mathrm{CO}_{2}$ adsorbed on the LDH surface. In addition, NCD also acts as electron sinks for efficient removal of electrons from conduction band of LDH to get reacted with adsorbed $\mathrm{CO}_{2}$ and converted to $\mathrm{CH}_{4}$.

Recently $\mathrm{Wu}$ and co-authors developed an efficient $\mathrm{NiFe}-\mathrm{LDH}$ wrapped $\mathrm{Cu}_{2} \mathrm{O}$ nanocube (NFC) heterostructure for enhanced photocatalytic $\mathrm{CO}_{2}$ conversion [67]. The NFC photocatalysts were synthesized by a simple co-precipitation approach with varied time of aging temperature. Figure 21a-c shows the SEM images of NiFe-LDH, $\mathrm{Cu}_{2} \mathrm{O}$ nanocubes and the NFC heterostructure photocatalyst, respectively. The $\mathrm{NiFe}-\mathrm{LDH}$ consisted of interconnected layers resulting in a flower like morphology, whereas $\mathrm{Cu}_{2} \mathrm{O}$ were in fine nanocubes. The NFC heterostructure shows a smooth structure of nanocubes covered with layers of LDH. The photocatalytic $\mathrm{CO}_{2}$ conversion for NFC photocatalyst yielded mainly $\mathrm{CH}_{4}$ as a key product. Figure $21 \mathrm{~d}$ shows the $\mathrm{CH}_{4}$ production rate for various samples with varied 
aging time, i.e., 1, 2, and $4 \mathrm{~h}$ represented by NFC-1, NFC-2, and NFC-4, respectively. The NFC-4 displayed the highest efficiency amongst all the samples. The authors proposed a Z-scheme mechanism for conversion of $\mathrm{CO}_{2}$ to $\mathrm{CH}_{4}$, shown in Figure 21e. It can be assumed that upon light irradiation, the electrons generated in $\mathrm{Cu}_{2} \mathrm{O}$ react to the adsorbed $\mathrm{CO}_{2}$ on NFC surface and are converted to $\mathrm{CH}_{4}$, while the holes in valence band are filled by the photogenerated electrons from LDH. Thus, the key factors involved for the enhanced efficiency include visible light absorption, efficient charge separation, and improved $\mathrm{CO}_{2}$ adsorption.
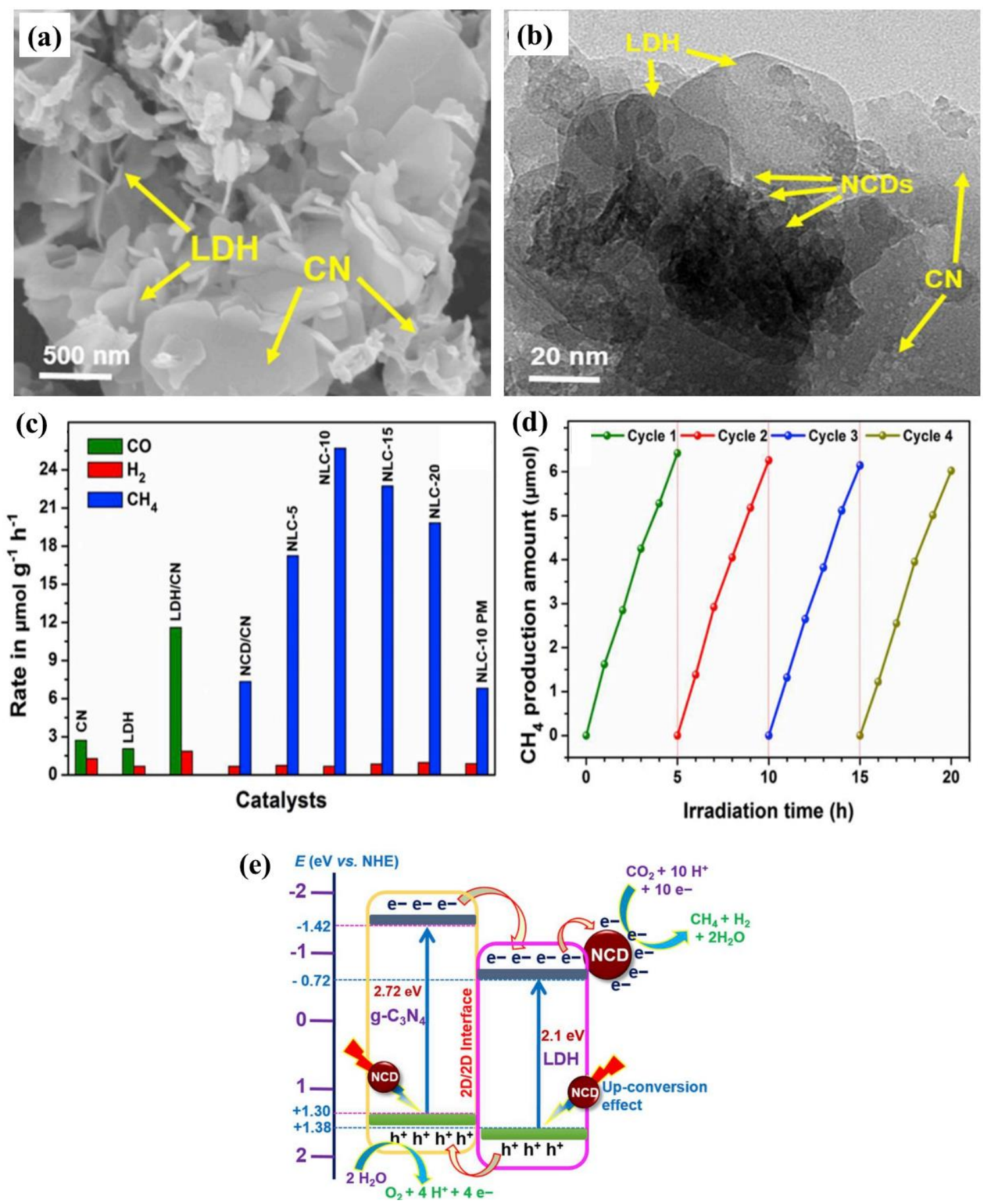

Figure 20. (a,b) TEM images for the hybrid NLC-10 photocatalyst. (c) Photocatalytic $\mathrm{CO}_{2}$ conversion from various samples to $\mathrm{CO}, \mathrm{H}_{2}$, and $\mathrm{CH}_{4}$, with (d) stable performance evaluation. (e) Schematic for the proposed mechanism of $\mathrm{CO}_{2}$ conversion to useful chemicals over the hybrid NLC photocatalyst surface. (Figures taken with permission from reference [66]. Copyright 2019, Elsevier). 

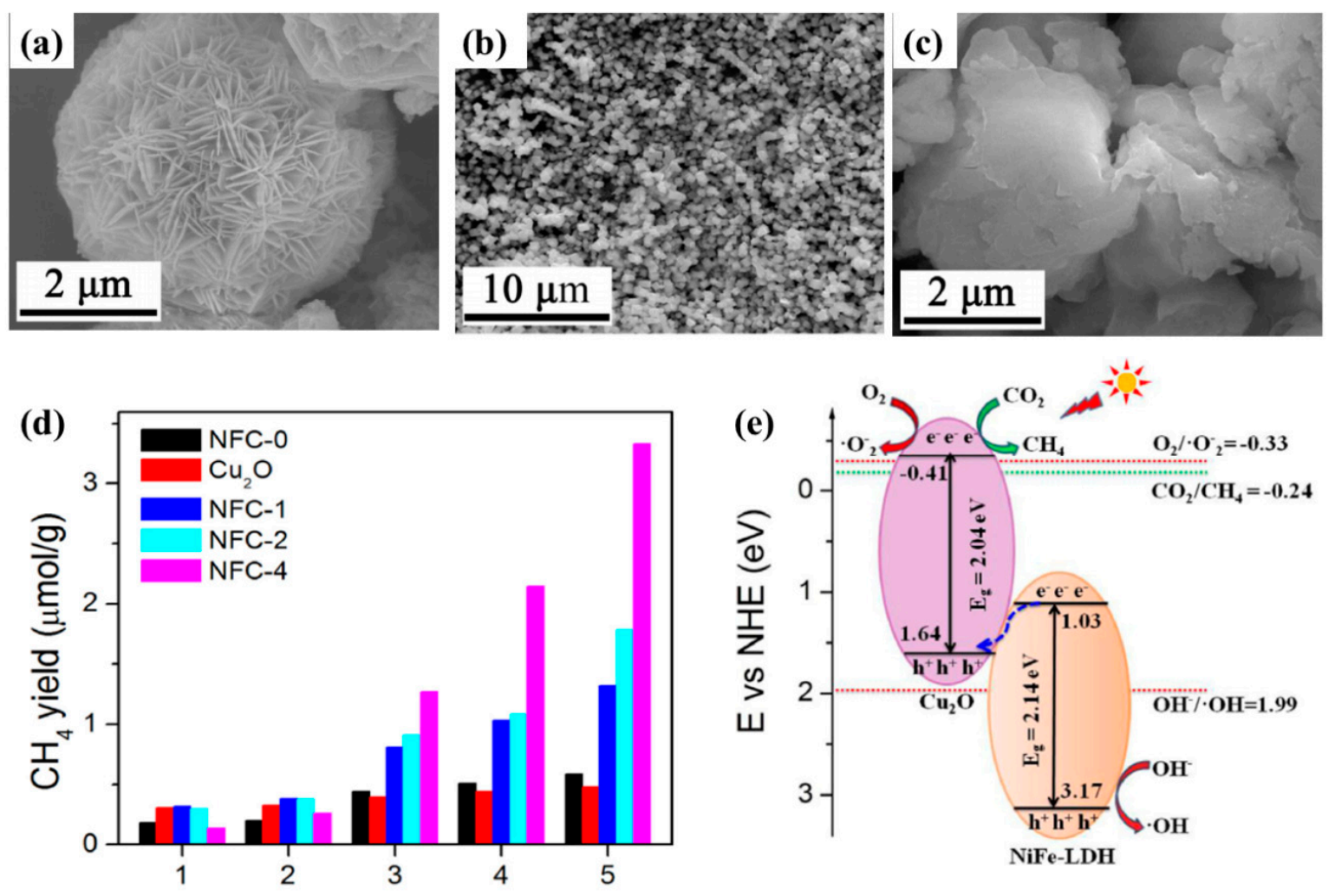

Figure 21. SEM images of (a) NiFe-LDH, (b) $\mathrm{Cu}_{2} \mathrm{O}$ Cuboids, and (c) hybrid NiFe-LDH-Cu $2 \mathrm{O}(\mathrm{NFC}-4$ Sample). (d) Photocatalytic $\mathrm{CO}_{2}$ conversion from reference and various NFC samples to $\mathrm{CH}_{4}$. (e) Proposed Z-scheme mechanism involved in PCC with band gap alignment. (Figures taken with permission from reference [67]. Copyright 2020, Elsevier).

Similarly, Jiang et al. reported $\mathrm{Cu}_{2} \mathrm{O}$ loaded $\mathrm{ZnCr} \mathrm{LDH}$ for $\mathrm{CO}_{2}$ photo-reduction to useful fuels [68]. The $\mathrm{Cu}_{2} \mathrm{O} @ \mathrm{ZnCr} \mathrm{LDH}$ was synthesized by a ternary $\mathrm{CuZnCr} \mathrm{LDH}$ via in situ reduction process. A variety of samples were prepared by in situ reduction of $\mathrm{Cu}_{2-x} \mathrm{Zn}_{2-2 x} \mathrm{Cr}$

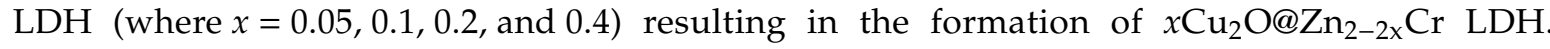
The photocatalytic $\mathrm{CO}_{2}$ conversion employing $x \mathrm{Cu}_{2} \mathrm{O} @ \mathrm{Zn}_{2-2 \mathrm{x}} \mathrm{Cr}$ LDH sample is shown in Figure 22a,b. The $\mathrm{CO}_{2}$ conversion to mainly $\mathrm{CO}$ was observed from the samples with $0.1 \mathrm{Cu}_{2} \mathrm{O} @ \mathrm{Zn}_{1.8} \mathrm{Cr} \mathrm{LDH}$ sample exhibiting the highest yield as compared to its corresponding reference samples (Figure 22a). The key behind the significantly enhanced activity after $\mathrm{Cu}$ loading was its superb electron extraction property from the photocatalyst. Figure 22c exhibits the $\mathrm{CO}_{2}$ conversion of various $x \mathrm{Cu}_{2} \mathrm{O} @ \mathrm{Zn}_{2-2 x} \mathrm{Cr}$ LDH samples, indicating the $0.1 \mathrm{Cu}_{2} \mathrm{O} @ \mathrm{Zn}_{1.8} \mathrm{Cr} \mathrm{LDH}$ sample is the most efficient photocatalyst with optimized loading of $\mathrm{Cu}$ content. Moreover, the effect of various additives was also investigated for $0.1 \mathrm{Cu}_{2} \mathrm{O} @ \mathrm{Zn}_{1.8} \mathrm{Cr} \mathrm{LDH}$ sample and is shown in Figure 22d. It was observed that $\mathrm{Na}_{2} \mathrm{SO}_{3}$ and $\mathrm{Na}_{2} \mathrm{CO}_{3}$ additives suppressed the formation of $\mathrm{CO}$ and enhanced the formation of $\mathrm{H}_{2}$, due to their better hole scavenging properties and occupying the $\mathrm{CO}_{2}$ adsorption sites. Figure 22e shows the proposed mechanism of $\mathrm{CO}_{2}$ photo-reduction for $0.1 \mathrm{Cu}_{2} \mathrm{O} @ \mathrm{Zn}_{1.8} \mathrm{Cr} \mathrm{LDH}$ sample. Upon light irradiation, the photogenerated electrons are extracted by $\mathrm{Cu}_{2} \mathrm{O}$ nanoparticles where they react with adsorbed $\mathrm{CO}_{2}$ species to yield $\mathrm{CO}$. Hence the key role of $\mathrm{Cu}_{2} \mathrm{O}$ nanoparticles on the surface of $0.1 \mathrm{Cu}_{2} \mathrm{O} @ \mathrm{Zn}{ }_{1.8} \mathrm{Cr} \mathrm{LDH}$ sample is an efficient electron separator providing $\mathrm{CO}_{2}$ active sites. 

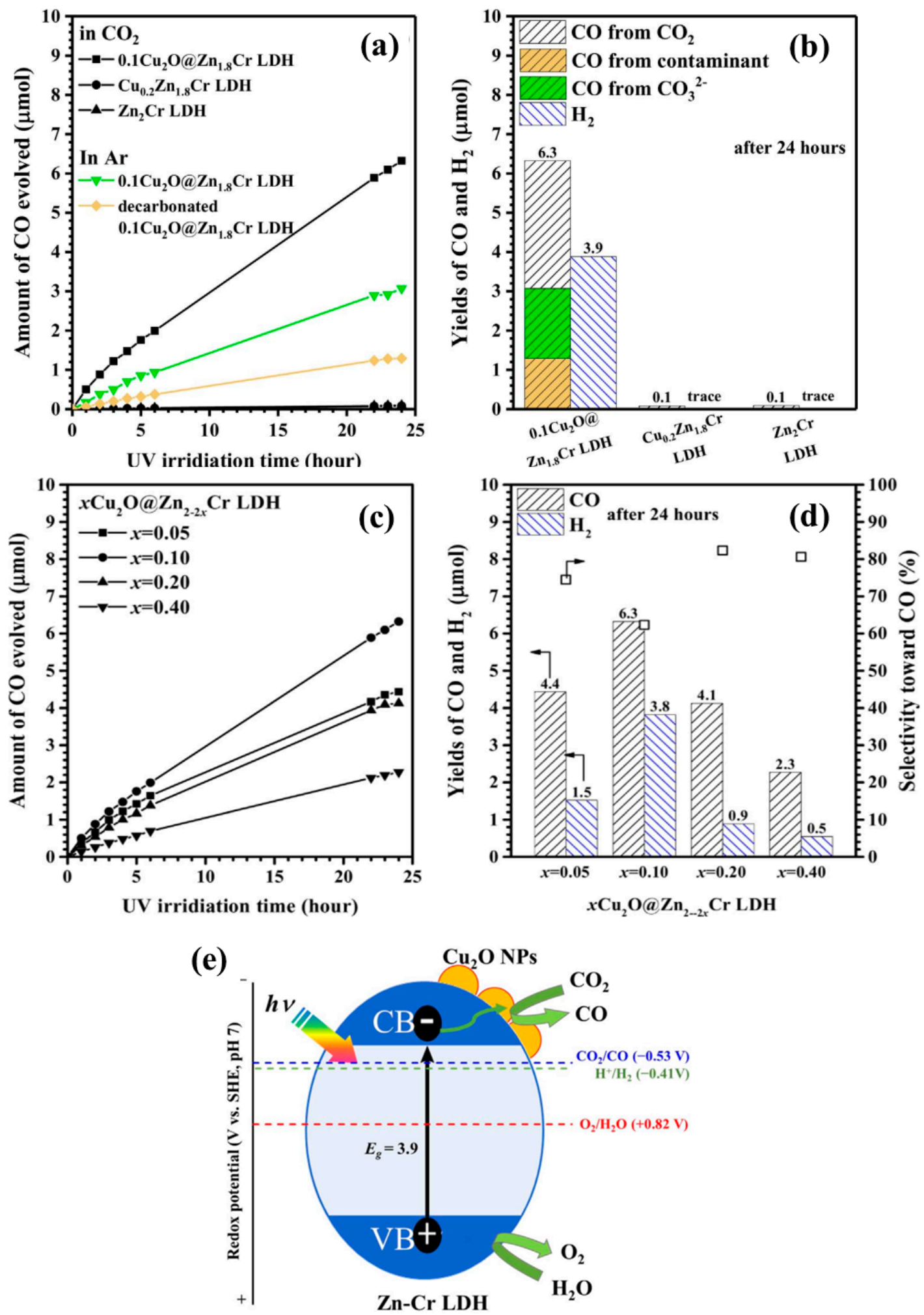

Figure 22. Photocatalytic $\mathrm{CO}_{2}$ conversion to $\mathrm{CO}$ and $\mathrm{H}_{2}$, (a) employing $0.1 \mathrm{Cu}_{2} \mathrm{O} @ \mathrm{ZnCr} \mathrm{LDH}$ samples under $\mathrm{CO}_{2}$ and Ar gaseous reactants; (b) amount of $\mathrm{CO}$ and $\mathrm{H}_{2}$ yielded after $24 \mathrm{~h}$ of reaction for employing 0.1Cu $\mathrm{u}_{2} \mathrm{O} @ \mathrm{ZnCr} \mathrm{LDH}$ samples, (c) under $\mathrm{CO}_{2}$ gaseous reactant for various $\mathrm{xCu_{2 }} @ \mathrm{O} \mathrm{ZnCr}$ $\mathrm{LDH}$ samples; and (d) amount of $\mathrm{CO}$ and $\mathrm{H}_{2}$ produced after $24 \mathrm{~h}$ for various $\mathrm{xCu}_{2} \mathrm{O} @ \mathrm{ZnCr} \mathrm{LDH}$ samples. (e) Proposed mechanism involved in PCC with band gap alignment. (Figures taken with permission from reference [68]. Copyright 2017, Elsevier). 
In another manner, LDH materials can be utilized as based material to synthesize efficient composite/heterojunctioned/hybrid photocatalysts. There are very limited reports regarding the utilization of LDH materials as photocatalyst precursors. To our best knowledge, in our investigation, we found a couple of research works taking advantage of mentioned approach and providing a novel pathway towards efficient photocatalysts development. Ye et al. reported $\mathrm{CeO}_{2-x}$ platelets from monometallic cerium $\mathrm{LDH}(\mathrm{MCe}-\mathrm{LDH})$ and evaluated their performance for photocatalytic $\mathrm{CO}_{2}$ conversion [69]. The synthesis approach consists of two steps including synthesis of MCe-LDH in the first step followed by second step of heat treatment at various temperatures up to $800{ }^{\circ} \mathrm{C}$. Figure $23 \mathrm{a}$ shows the SEM image of a synthesized un-calcined MCe-LDH displaying the quasi-hexagonal platelets. Figure $23 \mathrm{~b}$ shows the SEM image of the MCe-LDH calcined at a temperature of $800{ }^{\circ} \mathrm{C}$, thus indicating that thermal treatment does not change significantly the structure except for the increased density of the nanopores. Figure 23c exhibits the UV-Vis DRS for various samples. It was observed that MCe-LDH exhibits broad hump at $320 \mathrm{~nm}$, whereas when MCe-LDH were calcined, the absorption spectra showed two absorption peaks at 280 and $320 \mathrm{~nm}$, corresponding to the $\mathrm{Ce}^{3+}$ and $\mathrm{Ce}^{4+}$, respectively. The inset to UV-Vis DRS shows the absorption ratio for $\mathrm{Ce}^{3+}$ to $\mathrm{Ce}^{4+}$ with temperature. The MCe-LDH sample calcined at $800^{\circ} \mathrm{C}$ (MCe-LDH-800) shows the maximum ratio, whereas upon increasing the temperature up to $1000{ }^{\circ} \mathrm{C}$, the absorption ratio decreased due to structure distortion. Figure $23 \mathrm{~d}$ displays the photocatalytic $\mathrm{CO}_{2}$ conversion test with the synthesized and reference samples. It was observed that only $\mathrm{CO}$ was yielded, and sample calcined at $800{ }^{\circ} \mathrm{C}$ yielded the maximum $\mathrm{CO}$ production rate, 2.5 times higher than reference $\mathrm{CeO}_{2}$. Moreover, the optimized sample MCe-LDH-800 shows a stable photocatalytic performance for 4 cycles ( $8 \mathrm{~h}$ of each cycle) of testing. The photocatalytic performance was believed to be enhanced by two key factors of $\mathrm{Ce}^{3+} / \mathrm{Ce}^{4+}$ redox couple present at the surface of MCe-LDH and enhanced surface areas. The $\mathrm{Ce}^{3+} / \mathrm{Ce}^{4+}$ redox couple supports in the efficient charge separation, whereas improved surface areas lead to increased active sites for $\mathrm{CO}_{2}$ adsorption and conversion. The proposed mechanism by authors is shown in Figure 23e; under light irradiation, $\mathrm{Ce}^{4+}$ ions and oxygen vacancies will trap the photogenerated electrons. Such oxygen vacancy will promote the $\mathrm{CO}_{2}$ adsorption which will react with $\mathrm{Ce}^{3+}$ ions and get converted to $\mathrm{CO}_{2}{ }^{-}$, which will further react with electron and proton to give $\mathrm{CO}$. On the other hand, $\mathrm{Ce}^{3+}$ ions after reducing adsorbed $\mathrm{CO}_{2}$ will be converted to $\mathrm{Ce}^{4+}$ ions, and thus, the reaction cycle continues.

The summary of the reviewed composite photocatalysts with LDH with respective research aims, reaction condition, solar fuels production, and various contributing parameters to catalytic performance is tabulated in Table 3. 
Table 3. Summary of various $\mathrm{LDH}$ based composite photocatalysts with research goal, reaction conditions, value added chemicals production by photocatalytic $\mathrm{CO}_{2}$ conversion, and key parameters for improved performance.

\begin{tabular}{|c|c|c|c|c|c|}
\hline $\begin{array}{c}\text { LDH } \\
\text { Photo-Catalyst }\end{array}$ & Research Objective & $\begin{array}{l}\text { Light Source and } \\
\text { Reactants Employed }\end{array}$ & $\begin{array}{l}\text { Photo-Catalytic Activity, } \\
\mathrm{CO}_{2} \text { Conversion to Value } \\
\text { Added Chemicals }\end{array}$ & $\begin{array}{l}\text { Parameters Contributing towards } \\
\text { Improved Performance }\end{array}$ & Ref \\
\hline $\mathrm{MgAl}-\mathrm{LDO} / \mathrm{TiO}_{2}$ & $\begin{array}{l}\text { Investigation of } \\
\mathrm{MgAl}-\mathrm{LDO} / \mathrm{TiO}_{2} \\
\text { composite } \\
\text { photocatalysts for } \\
\text { PCC by varying the } \\
\text { ration of } \mathrm{Mg}+\mathrm{Al} \\
\text { to } \mathrm{Ti}\end{array}$ & $\begin{array}{l}50 \text { W Xe lamp with a } \\
\text { UV cut-off filter was } \\
\text { used as a } \\
\text { light irradiation } \\
\mathrm{CO}_{2} \text { bubbled } \\
\text { through water was } \\
\text { used as a reactant }\end{array}$ & $\begin{array}{l}\text { - Sample with } 10 \text { wt.\% of } \\
\text { MgAl-LDO } \mathrm{TiO}_{2} \text { yields } \\
\text { the best performance } \\
\text { with production rate of } \\
\mathrm{CO}: 4.3 \mu \mathrm{mol} \mathrm{g}^{-1} \mathrm{~h}^{-1} \\
\text { (under } \mathrm{UV}_{\mathrm{ight}} \mathrm{CO} \text { : } \\
1.0 \mu \mathrm{mol} \mathrm{g}^{-1} \mathrm{~h}^{-1} \text { (under } \\
\text { Visible light) }\end{array}$ & $\begin{array}{l}\text { - Ratio of } \mathrm{Mg}+\mathrm{Al} \text { to } \mathrm{Ti} \text { in the } \\
\text { composite } \mathrm{LDH} \text { enhances the } \\
\mathrm{CO}_{2} \text { adsorption } \\
\text { Under light irradiation, } \\
\text { the photogenerated charges form } \\
\mathrm{TiO}_{2} \text { can travel to adsorbed } \mathrm{CO}_{2} \\
\text { and photoreduce to } \\
\text { respective product }\end{array}$ & [61] \\
\hline $\begin{array}{l}\text { P25@CoAl- LDH Nano } \\
\text { Composite }\end{array}$ & $\begin{array}{l}\text { A facile and } \\
\text { cost-effective } \\
\text { synthesis strategy for } \\
\text { P25 encapsulated } \\
\text { CoAl-LDH with } \\
\text { improved } \\
\mathrm{CO}_{2} \text { photoreduction }\end{array}$ & $\begin{array}{l}\text { - } \quad \text { UV-Vis and visible } \\
\text { light is obtained } \\
\text { from } 300 \mathrm{~W} \text { Xe lamp } \\
\mathrm{CO}_{2} \text { gas was } \\
\text { bubbled through } \\
\text { water containing } \\
\text { suspended photocatalyst }\end{array}$ & $\begin{array}{l}\text { - } 20 \text { wt.\% P25@CoAl- } \\
\text { LDH yielded the best } \\
\text { production rate of CO: } \\
2.21 \mu \mathrm{mol} \mathrm{g}^{-1} \mathrm{~h}^{-1} \\
\text { (UV-Vis light } \\
\text { irradiation) CO: } \\
0.714 \mu \mathrm{mol} \mathrm{g}^{-1} \mathrm{~h}^{-1} \text { (with } \\
\text { visible light irradiation) }\end{array}$ & $\begin{array}{l}\text { The type II junctions formed } \\
\text { between P25 and CoAl LDH lead } \\
\text { to the efficient separation of } \\
\text { photogenerated electro-hole pairs } \\
\text { leading to enhanced CO yield } \\
\text { The bandgap positions well } \\
\text { aligned to produce selectively CO } \\
\text { with a value of greater than } 90 \%\end{array}$ & [62] \\
\hline $\mathrm{BiOCl}-\mathrm{ZnCr}-\mathrm{LDH}$ & $\begin{array}{l}\text { The development of } \\
\text { homo-hetero } \\
\text { junctioned } \\
\text { BiOCl-ZnCr-LDH } \\
\text { for efficient } \\
\mathrm{CO}_{2} \text { photo-reduction }\end{array}$ & $\begin{array}{l}\text { - Light is obtained } \\
\text { from } 500 \mathrm{~W} \\
\text { Xenon Lamp } \\
\mathrm{CO}_{2} \text { bubbled } \\
\text { through water was } \\
\text { used as a reactant }\end{array}$ & 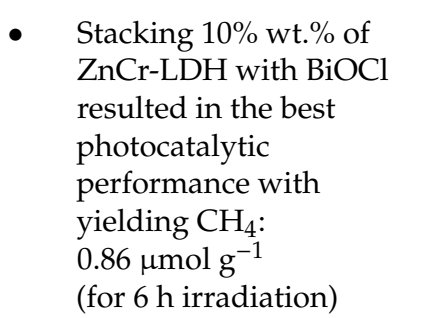 & $\begin{array}{l}\text { - The composite formation of } \\
\text { ZnCr-LDH with BiOCl, resulting } \\
\text { in homo-hetero junctioned } \\
\text { system which lead to improved } \\
\text { holes separation and thus } \\
\text { enhanced } \\
\text { photocatalytic performance }\end{array}$ & [63] \\
\hline
\end{tabular}


Table 3. Cont.

\begin{tabular}{|c|c|c|c|c|c|}
\hline $\begin{array}{c}\text { LDH } \\
\text { Photo-Catalyst }\end{array}$ & Research Objective & $\begin{array}{l}\text { Light Source and } \\
\text { Reactants Employed }\end{array}$ & $\begin{array}{c}\text { Photo-Catalytic Activity, } \mathrm{CO}_{2} \\
\text { Conversion to Value Added } \\
\text { Chemicals }\end{array}$ & $\begin{array}{l}\text { Parameters Contributing towards } \\
\text { Improved Performance }\end{array}$ & Ref \\
\hline $\begin{array}{c}\text { In situ loaded RGO and } \\
\text { g- } \mathrm{C}_{3} \mathrm{~N}_{4} \text { on } \\
\text { CoZnAl-LDH, } \\
\text { represented by } \\
\mathrm{LDH} / \mathrm{RGO} / \mathrm{CN}\end{array}$ & $\begin{array}{l}\text { - Synthesis of a } \\
\text { Z-scheme } \\
\text { hybrid Photocatalysts } \\
\text { Investigation of } \\
\text { various components } \\
\text { for improved } \\
\mathrm{CO}_{2} \text { photoreduction }\end{array}$ & 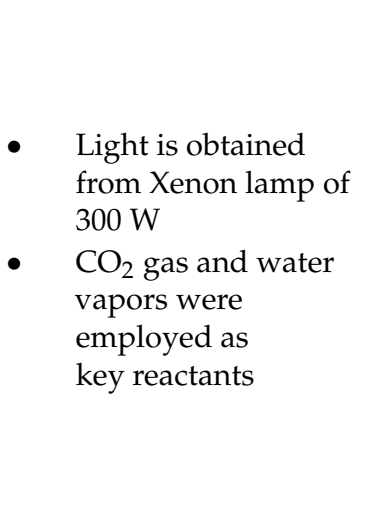 & 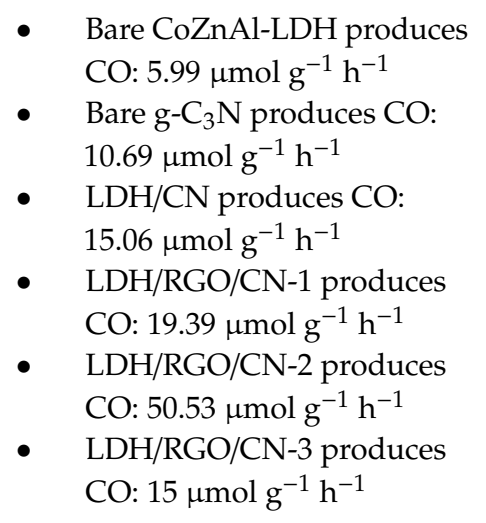 & $\begin{array}{l}\text { The optimum content of } \mathrm{g}-\mathrm{C}_{3} \mathrm{~N}_{4} \\
\text { provides the best performance } \\
\text { due to increased charge lifetime } \\
\text { and enhanced separation via } \\
\text { Z-scheme mechanism } \\
\text { The RGO acts as an electron } \\
\text { mediator at the junction of } \mathrm{CN} \\
\text { and LDH }\end{array}$ & [64] \\
\hline $\mathrm{Y@S} \mathrm{TiO}_{2-\mathrm{x}} / \mathrm{LDH}$ & $\begin{array}{l}\text { Development of a } \\
\text { novel 3-D } \\
\text { nanoarchitecture for } \\
\text { efficient } \\
\mathrm{CO}_{2} \text { photoreduction } \\
\text { Investigation of time } \\
\text { dependent } \\
\text { experiments for } \\
\text { selective } \\
\text { fuel/chemical production }\end{array}$ & $\begin{array}{l}\text { Light is obtained } \\
\text { from Xenon lamp of } \\
300 \mathrm{~W} \\
\mathrm{CO}_{2} \text { was bubbled } \\
\text { through water and } \\
\text { used as key reactants }\end{array}$ & $\begin{array}{l}\text { - } \quad \mathrm{Y} @ \mathrm{TiO}_{2-\mathrm{x}} / \mathrm{LDH} \text { yielded } \\
\mathrm{CH}_{3} \mathrm{OH} / \mathrm{CH}_{4} \text { with respect to } \\
\text { time of irradiation } \\
\text { For } 2 \mathrm{~h} \text { of irradiation, } \\
\text { the key product obtained } \\
\text { was } \mathrm{CH}_{3} \mathrm{OH} \text { : } \\
216 \mu \mathrm{mol} \mathrm{g}^{-1} \mathrm{~h}^{-1} \\
\text { After } 12 \mathrm{~h} \text { of irradiation, }^{-} \\
\text {the amounts of } \mathrm{CH}_{3} \mathrm{OH} \text { and } \\
\mathrm{CH}_{4} \text { increased to } 726 \text { and } \\
453 \mu \mathrm{mol} \mathrm{g}^{-1} \text {, respectively }\end{array}$ & $\begin{array}{l}\text { Advanced architecture of } \mathrm{Y} @ \mathrm{~S} \\
\mathrm{TiO}_{2} \text { containing } \\
\text { oxygenvacancies linked with } \\
\mathrm{LDH} \text { plates enhances } \mathrm{CO}_{2} \\
\text { absorption in defect sites } \\
\text { and interlayerspaces } \\
\text { Moreover, } \mathrm{TiO}_{2-x} \text { provides a } \\
\text { better light absorption with } \\
\text { narrower band gap } \\
\text { The time dependent selectivity } \\
\text { was attributed to the conversion } \\
\text { of radicals adsorbed to } \mathrm{CH}_{4} \text { and } \\
\mathrm{CH}_{3} \mathrm{OH}\end{array}$ & [65] \\
\hline
\end{tabular}


Table 3. Cont.

\begin{tabular}{|c|c|c|c|c|c|}
\hline $\begin{array}{c}\text { LDH } \\
\text { Photo-Catalyst }\end{array}$ & Research Objective & $\begin{array}{l}\text { Light Source and } \\
\text { Reactants Employed }\end{array}$ & $\begin{array}{c}\text { Photo-Catalytic Activity, } \mathrm{CO}_{2} \\
\text { Conversion to Value Added } \\
\text { Chemicals }\end{array}$ & $\begin{array}{l}\text { Parameters Contributing towards } \\
\text { Improved Performance }\end{array}$ & Ref \\
\hline $\begin{array}{l}\mathrm{NiFe}-\mathrm{LDH} \text { wrapped } \\
\mathrm{Cu}_{2} \mathrm{O} \text { nanocubes, } \\
(\mathrm{NFC})\end{array}$ & $\begin{array}{l}\text { Inexpensive and } \\
\text { facile synthesis of } \\
\text { Z-scheme 2-D } \\
\text { NiFe-LDH and } \\
\mathrm{Cu}_{2} \mathrm{O} \text { nanocubes for } \\
\text { efficient } \\
\mathrm{CO}_{2} \text { photoreduction }\end{array}$ & 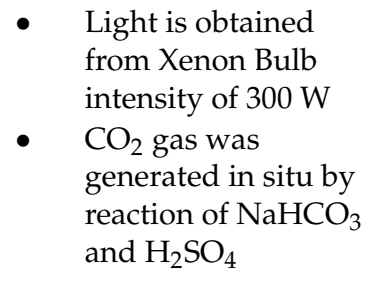 & $\begin{array}{l}\text { - } \mathrm{NFC}-4 \text { with } 4 \mathrm{hr} \text { of aging at } \\
65^{\circ} \mathrm{C} \text { yielded the best solar } \\
\text { fuel, i.e., } \mathrm{CH}_{4} \text { around } \\
3.33 \mathrm{mmol} \mathrm{g}^{-1} \text { for } 4 \mathrm{~h} \\
\text { irradiation, which is about } \\
6.9 \text { times of } \mathrm{Cu}_{2} \mathrm{O} \text { and } \\
5.6 \text { times of } \mathrm{NiFe}-\mathrm{LDH}\end{array}$ & $\begin{array}{l}\text { Z-scheme mechanism for charge } \\
\text { separation and improved light } \\
\text { absorption were the key reason } \\
\text { for enhanced } \mathrm{CH}_{4} \text { yield }\end{array}$ & [67] \\
\hline $\mathrm{xCu}_{2} \mathrm{O} @ \mathrm{Zn}_{2-2 \mathrm{x}} \mathrm{Cr} \mathrm{LDH}$ & $\begin{array}{l}\text { - Inexpensive facile } \\
\text { strategy to } \\
\text { synthesize the } \\
\text { ternary LDH } \\
\text { photocatalyst for } \\
\text { efficient } \\
\mathrm{CO}_{2} \text { photoreduction }\end{array}$ & $\begin{array}{l}\text { - UV light is obtained } \\
\text { from } 200 \text { W Xe lamp } \\
\mathrm{CO}_{2} \text { was bubbled } \\
\text { through DI water } \\
\text { containing respective } \\
\text { photocatalysts in } \\
\text { suspended form }\end{array}$ & $\begin{array}{l}\mathrm{Cu}_{2} \mathrm{O} @ \mathrm{Zn}_{2-2 x} \mathrm{Cr} \mathrm{LDH} \\
\text { produces maximum yield of } \\
\text { solar products (for } 24 \mathrm{~h} \text { ), } \\
\text { which contains, } \mathrm{H}_{2}: \\
41.2 \mu \text { mol and } \mathrm{CO}: 0.8 \mu \mathrm{mol} \\
\text { with additive of } \mathrm{Na}_{2} \mathrm{SO}_{4}\end{array}$ & $\begin{array}{l}\text { - The loaded } \mathrm{Cu}_{2} \mathrm{O} \text { nanoparticles } \\
\text { acts as an efficient electron } \\
\text { extractor from } \\
\mathrm{LDH} \text { photocatalyst } \\
\text { The addition of } \mathrm{Na}_{2} \mathrm{SO}_{3} \\
\text { suppresses the generation of } \mathrm{CO} \\
\text { and promotes the water } \\
\text { splitting leading to formation of } \\
\mathrm{H}_{2} \text {. }\end{array}$ & [68] \\
\hline $\begin{array}{l}\text { Mono-metallic Cerium } \\
\text { LDH } \\
\text { (MCe-LDH) }\end{array}$ & $\begin{array}{l}\text { - Synthesis of } \\
\text { MCe-LDH by a } \\
\text { simple and } \\
\text { facile approach } \\
\text { - Investigation of the } \\
\text { heat treatment effect } \\
\text { at various } \\
\text { temperatures for } \\
\mathrm{CO}_{2} \text { photoreduction }\end{array}$ & $\begin{array}{l}\text { UV-Vis light } \\
\text { obtained from } 300 \mathrm{~W} \\
\text { Xenon lamp } \\
\mathrm{CO}_{2} \text { and water } \\
\text { vapors were used as } \\
\text { reactant in } \\
\text { gaseous phase }\end{array}$ & $\begin{array}{l}\text { MCe-LDH heated upto } \\
800{ }^{\circ} \mathrm{C} \text { yielded the } \\
\text { maximum CO yield of } \\
13.4 \mu \mathrm{mol} \mathrm{g}^{-1} \text { in } 8 \mathrm{~h}\end{array}$ & $\begin{array}{l}\text { Heat treatment resulted in } \\
\text { enhancement of concentration } \\
\text { ratio of and increased surface } \\
\text { area, both factors enhanced the } \\
\text { photo reduction of } \mathrm{CO}_{2}\end{array}$ & [69] \\
\hline
\end{tabular}



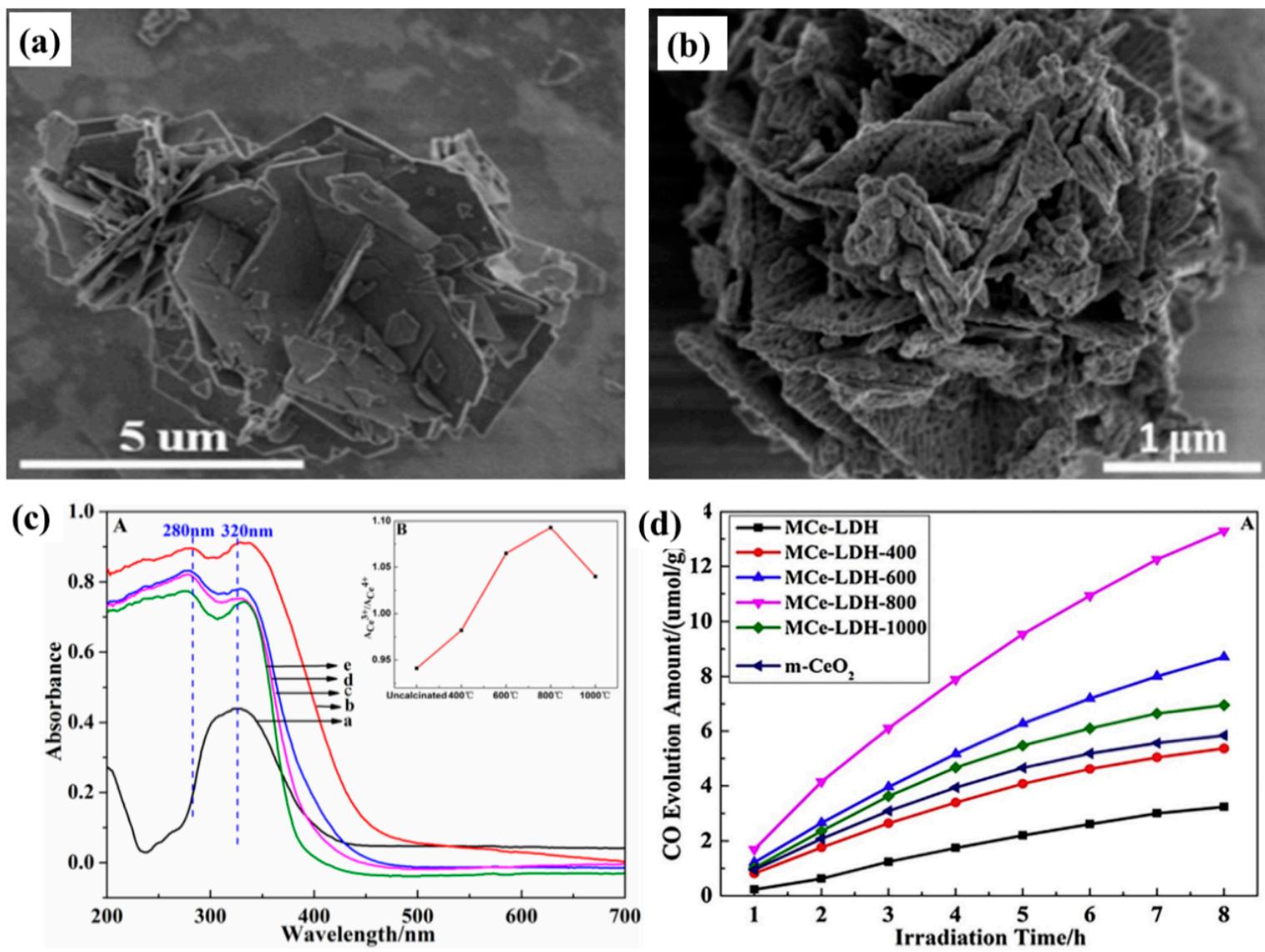

(e)

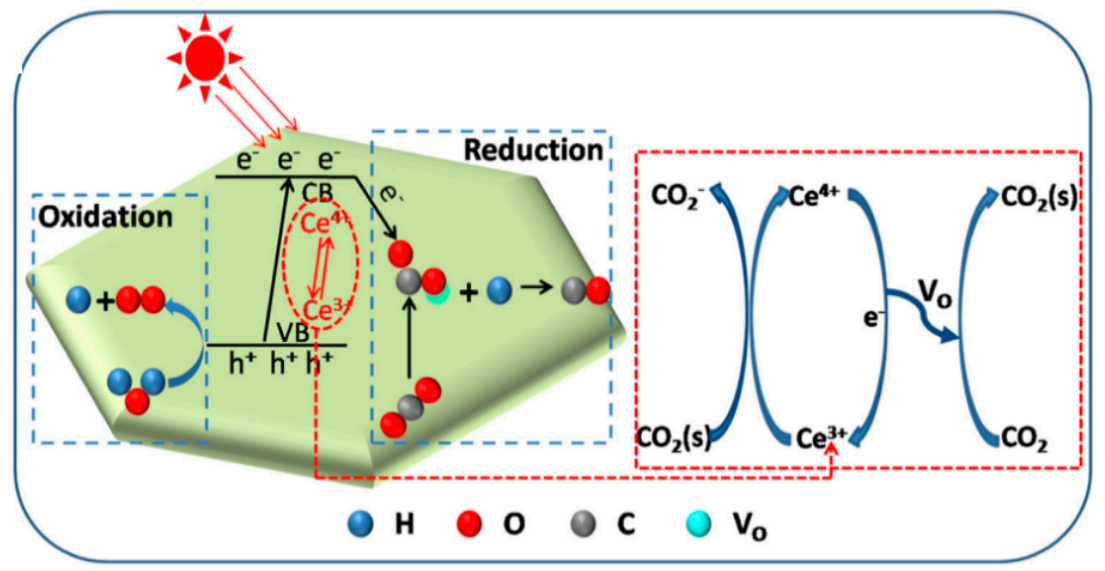

Figure 23. SEM images of (a) MCe-LDH and, (b) MCe-LDH calcined at $800^{\circ} \mathrm{C}$. (c) UV-Vis DRS spectra of the various reference and synthesized samples in the respective research work. (d) Photocatalytic $\mathrm{CO}_{2}$ conversion from various MCe-LDH samples to $\mathrm{CO}$. (e) Schematic of the mechanism involved in PCC with $\mathrm{H}_{2} \mathrm{O}$. (Figures taken with permission from reference [69]. Copyright 2017, Elsevier).

\section{Conclusions}

The review mainly focusses on the progress of LDH and LDH based photocatalysts for photocatalytic $\mathrm{CO}_{2}$ conversion. The influential properties, reaction conditions, proposed mechanisms, and various influential aspects for photocatalytic $\mathrm{CO}_{2}$ conversion were comprehensively explained. The interesting and mind captivating behavior of LDH photocatalysts for improved photocatalytic performance can be attributed to a combination of prime parameters which include (i) improved $\mathrm{CO}_{2}$ adsorption, (ii) improved light absorption, (iii) improved separation of photogenerated charges, and (iv) better product selectivity due to band gap alignment. Furthermore, surface modification 
of LDH, effect of various additives, noble metals loading/embedding, wrapping with graphene derivatives, and hybrid LDH based heterojunctioned photocatalysts were studied and explained principally. Conclusively, it can be inferred that LDH and/or LDH based photocatalysts open up a new way towards the alternate and efficient photocatalysts with a great potential for efficient for photocatalytic $\mathrm{CO}_{2}$ conversion into useful chemicals/fuels.

Author Contributions: A.R. collected the data, analyzed it, and wrote the review. S.A. reviewed and modified the manuscript. M.A. analyzed and tabulated the data, and S.-I.I. analyzed, modified, and rewrote the manuscript. All authors have read and agreed to the published version of the manuscript.

Funding: The authors are thankful towards the Ministry of Science and ICT and the Technology Development Program to Solve Climate Changes of the National Research Foundation (NRF) funded by the Ministry of Science and ICT for financial support under the grant numbers 2017R1E1A1A01074890 and 2015M1A2A2074670, respectively.

Acknowledgments: The authors gratefully acknowledge the support of the Ministry of Science and ICT, and the Technology Development Program to Solve Climate Changes of the National Research Foundation (NRF) funded by the Ministry of Science. The authors also acknowledge the Flux Photon Corporation for their support.

Conflicts of Interest: The authors declare no conflict of interest.

\section{References}

1. Cherniwchan, J. Economic growth, industrialization, and the environment. Resour. Energy Econ. 2012, 34, 442-467. [CrossRef]

2. Aznar-Márquez, J.; Ruiz-Tamarit, J.R. Environmental pollution, sustained growth, and suf fi cient conditions for sustainable development. Econ. Model. 2016, 54, 439-449. [CrossRef]

3. Li, K.; Lin, B. Impacts of urbanization and industrialization on energy consumption $/ \mathrm{CO}_{2}$ emissions: Does the level of development matter? Renew. Sustain. Energy Rev. 2015, 52, 1107-1122. [CrossRef]

4. Rabab, S.; Zaman, K.; Mushtaq, M.; Ahmad, M. Energy for economic growth, industrialization, environment and natural resources: Living with just enough. Renew. Sustain. Energy Rev. 2013, 25, 580-595.

5. Yujie, S. As featured in: Steering charge kinetics in photocatalysis: Intersection of materials syntheses. Chem. Soc. Rev. 2015, 44, 2893-2939.

6. White, J.L.; Baruch, M.F.; Iii, J.E.P.; Hu, Y.; Fortmeyer, I.C.; Park, J.E.; Zhang, T.; Liao, K.; Gu, J.; Yan, Y. Light-Driven Heterogeneous Reduction of Carbon Dioxide: Photocatalysts and Photoelectrodes. Chem. Rev. 2015, 115, 12888-12935. [CrossRef] [PubMed]

7. Tu, W.; Zhou, Y.; Zou, Z. Photocatalytic Conversion of $\mathrm{CO}_{2}$ into Renewable Hydrocarbon Fuels: State-of-the-Art Accomplishment, Challenges and Prospects. Adv. Mater. 2014, 26, 4607-4626. [CrossRef] [PubMed]

8. Inoue, T.; Fujishima, A.; Konishi, S.; Honda, K. Photoelectrocatalytic reduction of carbon dioxide in aqueous suspensions of semiconductor powders. Nature 1979, 277, 637-638. [CrossRef]

9. Mo, S.; Ching, W. Electronic and optical properties of three phases of titaniumdioixde: Rutile, anatase, and brookite. Phys. Rev. 1995, 51, 23-32. [CrossRef]

10. Mao, J.; Peng, T.; Zhang, X.; Li, K.; Ye, L.; Zan, L. Effect of graphitic carbon nitride microstuctures on the activity and selectivity of photocatalytic $\mathrm{CO}_{2}$ reduction under visible light. Catal. Sci. Technol. 2013, 5, 1253-1260. [CrossRef]

11. Peng, F.; Wang, J.; Ge, G.; He, T.; Cao, L.; He, Y.; Ma, H.; Sun, S. Photochemical reduction of $\mathrm{CO}_{2}$ catalyzed by silicon nanocrystals produced by high energy ball milling. Mater. Lett. 2013, 92, 65-67. [CrossRef]

12. Hsu, H.-C.; Shown, I.; Chang, Y.-C.; Du, H.-Y.; Lin, Y.-G.; Tseng, C.-A.; Wang, C.-H.; Chen, L.-C.; Lin, Y.-C.; Chen, K.-H. Graphene oxide as a promising photocatalyst for $\mathrm{CO}_{2}$ to methanol conversion. Nanosclae 2013, 5, 262-268. [CrossRef]

13. Liu, L.; Zhao, H.; Andino, J.M.; Li, Y. Photocatalytic $\mathrm{CO}_{2}$ Reduction with $\mathrm{H}_{2} \mathrm{O}$ on $\mathrm{TiO}_{2}$ Nanocrystals: Comparison of Anatase, Rutile, and Brookite Polymorphs and Exploration of Surface Chemistry. ACS Catal. 2012, 8, 1817-1822. [CrossRef]

14. Ali, S.; Flores, M.C.; Razzaq, A.; Sorcar, S.; Hiragond, C.B.; Kim, H.R.; Park, Y.H.; Hwang, Y.; Kim, H.S.; Kim, H.; et al. Gas Phase Photocatalytic $\mathrm{CO}_{2}$ Reduction, "A Brief Overview for Benchmarking". Catalysts 2019, 9, 727. [CrossRef] 
15. Parayil, S.K.; Razzaq, A.; Park, S.; Kim, H.R.; Grimes, C.A.; In, S.I. Photocatalytic conversion of $\mathrm{CO}_{2}$ to hydrocarbon fuel using carbon and nitrogen co-doped sodium titanate nanotubes. Appl. Catal. A Gen. 2015, 498, 205-213. [CrossRef]

16. Razzaq, A.; Sinhamahapatra, A.; Kang, T.; Grimes, C.A.; Yu, J.; In, S.-I. Efficient solar light photoreduction of $\mathrm{CO}_{2}$ to hydrocarbon fuels via magnesiothermally reduced $\mathrm{TiO}_{2}$ photocatalyst. Appl. Catal. B Environ. 2017, 215, 28-35. [CrossRef]

17. In, S.-I.; Ii, D.D.V.; Schaak, R.E. Hybrid CuO-TiO ${ }_{2-\mathrm{x}} \mathrm{N}_{\mathrm{x}}$ Hollow Nanocubes for Photocatalytic Conversion of CO 2 into Methane under Solar Irradiation. Angew. Chem. 2012, 3915-3918. [CrossRef]

18. Park, S.-M.; Razzaq, A.; Park, Y.H.; Sorcar, S.; Park, Y.; Grimes, C.A.; In, S.-I. Hybrid $\mathrm{Cu}_{\mathrm{x}} \mathrm{O}_{-} \mathrm{TiO}_{2}$ Heterostructured Composites for Photocatalytic $\mathrm{CO}_{2}$ Reduction into Methane Using Solar Irradiation: Sunlight into Fuel. ACS Omega 2016, 1, 868-875. [CrossRef]

19. Zubair, M.; Razzaq, A.; Grimes, C.A.; In, S.-I. $\mathrm{Cu}_{2} \mathrm{ZnSnS}_{4}(\mathrm{CZTS})-\mathrm{ZnO}$ : A noble metal-free hybrid Z-scheme photocatalyst for enhanced solar-spectrum photocatalytic conversion of $\mathrm{CO}_{2}$ to $\mathrm{CH}_{4}$. J. $\mathrm{CO}_{2}$ Util. 2017, 20, 301-311. [CrossRef]

20. Parayil, S.K.; Razzaq, A.; In, S.-I. Formation of titania-silica mixed oxides in solvent mixtures and their influences for the photocatalytic $\mathrm{CO}_{2}$ conversion to hydrocarbon. J. Nanosci. Nanotechnol. 2015, 15, 7285-7292. [CrossRef]

21. Kim, K.; Razzaq, A.; Sorcar, S.; Park, Y.; Grimes, A. RSC Advances conversion of $\mathrm{CO}_{2}$ into $\mathrm{CH}_{4}$ under solar irradiation. RSC Adv. 2016, 6, 38964-38971. [CrossRef]

22. Razzaq, A.; Grimes, C.A.; In, S.-I. Facile fabrication of a noble metal-free photocatalyst: $\mathrm{TiO}_{2}$ nanotube arrays covered with reduced graphene oxide. Carbon 2016, 98, 537-544. [CrossRef]

23. Rim, H.; Razzaq, A.; Grimes, C.A.; In, S.-I. Heterojunction p-n-p Cu $2 \mathrm{O} / \mathrm{S}-\mathrm{TiO}_{2} / \mathrm{CuO}$ : Synthesis and application to photocatalytic conversion of $\mathrm{CO}_{2}$ to methane. J. $\mathrm{CO}_{2}$ Util. 2017, 20, 91-96.

24. Hiragond, C.; Ali, S.; Sorcar, S.; In, S.-I. Hierarchical Nanostructured Photocatalysts for $\mathrm{CO}_{2}$ Photoreduction. Catalysts 2019, 9, 370. [CrossRef]

25. Ali, S.; Razzaq, A.; In, S.-I. Development of graphene based photocatalysts for $\mathrm{CO}_{2}$ reduction to $\mathrm{C} 1$ chemicals: A brief overview. Catalysts 2018, 335, 39-54. [CrossRef]

26. Ali, S.; Lee, J.; Kim, H.; Hwang, Y.; Razzaq, A.; Jung, J.; Cho, C.; In, S.-I. Sustained, photocatalytic $\mathrm{CO}_{2}$ reduction to $\mathrm{CH}_{4}$ in a continuous flow reactor by earth-abundant materials: Reduced titania-Cu $2 \mathrm{O}$ Z-scheme heterostructures. Appl. Catal. B Environ. 2020, 279, 119344. [CrossRef]

27. Daud, M.; Hai, A.; Banat, F.; Wazir, M.B.; Habib, M.; Bharath, G.; Al-harthi, M.A. A review on the recent advances, challenges and future aspect of layered double hydroxides (LDH) - Containing hybrids as promising adsorbents for dyes removal. J. Mol. Liq. 2019, 288, 110989. [CrossRef]

28. Mohapatra, L.; Parida, K. A review on the recent progress, challenges and perspective of layered double hydroxides as promising photocatalysts. J. Mater. Chem. A Mater. Energy Sustain. 2016, 4, 10744-10766. [CrossRef]

29. Long, X.; Wang, Z.; Xiao, S.; An, Y.; Yang, S. Transition metal based layered double hydroxides tailored for energy conversion and storage. Biochem. Pharmacol. 2016, 19, 213-226. [CrossRef]

30. Zhang, W.; Li, N.; Xie, Z.; Liu, Z.; Huang, Q. ScienceDirect Defective layered double hydroxide formed by $\mathrm{H}_{2} \mathrm{O}_{2}$ treatment act as highly efficient electrocatalytic for oxygen evolution reaction. Int. J. Hydrog. Energy 2019, 44, 21858-21864. [CrossRef]

31. Hou, L.; Du, Q.; Su, L.; Di, S.; Ma, Z.; Chen, L.; Shao, G. Ni-Co layered double hydroxide with self-assembled urchin like morphology for asymmetric supercapacitors. Mater. Lett. 2019, 237, 262-265. [CrossRef]

32. Prasad, C.; Tang, H.; Qin, Q.; Zul, S.; Shah, S.; Bahadur, I. An overview of semiconductors/layered double hydroxides composites: Properties, synthesis, photocatalytic and photoelectrochemical applications. J. Mol. Liq. 2019, 289, 111114. [CrossRef]

33. Chatterjee, A.; Bharadiya, P.; Hansora, D. Layered double hydroxide based bionanocomposites. Appl. Clay Sci. 2019, 177, 19-36. [CrossRef]

34. Cao, Y.; Li, G.; Li, X. Graphene/layered double hydroxide nanocomposite: Properties, synthesis and applications. Chem. Eng. J. 2016, 292, 207-223. [CrossRef]

35. Feitknecht, W.; Gerber, M. Acknowledgement of the double hydroxide and base double salt III Manesium-aluminium double hydroxide. Helv. Chim. Acta 1942, 27, 131-137. [CrossRef] 
36. Allmann, R. The crystal structure of pyroaurite. Acta Crystallogr. Sect. B Struct. Crystallogr. Cryst. Chem. 1968, 24, 972-977. [CrossRef]

37. Liu, X.; Shao, Y.; Zhang, Y.; Meng, G.; Zhang, T.; Wang, F. Using high-temperature mechanochemistry treatment to modify iron oxide and improve the corrosion performance of epoxy coating. High-temperature ball milling treatment. Corros. Sci. 2015, 90, 451-462. [CrossRef]

38. Zhang, Q.; Wang, J.; Yin, S.; Sato, T.; Saito, F. Synthesis of a visible-light active $\mathrm{TiO}_{2-\mathrm{x}} \mathrm{S}_{\mathrm{x}}$ photocatalyst by means of mechanochemical doping. J. Am. Ceram. Soc. 2004, 87, 1161-1163. [CrossRef]

39. Olfs, H.W.; Torres-Dorante, L.O.; Eckelt, R.; Kosslick, H. Comparison of different synthesis routes for Mg-Al layered double hydroxides (LDH): Characterization of the structural phases and anion exchange properties. Appl. Clay Sci. 2009, 43, 459-464. [CrossRef]

40. Theiss, F.L.; Ayoko, G.A.; Frost, R.L. Synthesis of layered double hydroxides containing $\mathrm{Mg}^{2+}, \mathrm{Zn}^{2+}$, $\mathrm{Ca}^{2+}$ and $\mathrm{Al}^{3+}$ layer cations by co-precipitation methods-A review. Appl. Surf. Sci. 2016, 383, $200-213$. [CrossRef]

41. Wang, Q.; Ohare, D. Recent advances in the synthesis and application of layered double hydroxide (LDH) nanosheets. Chem. Rev. 2012, 112, 4124-4155. [CrossRef] [PubMed]

42. Arai, Y.; Ogawa, M. Preparation of Co-Al layered double hydroxides by the hydrothermal urea method for controlled particle size. Appl. Clay Sci. 2009, 42, 601-604. [CrossRef]

43. Han, S.H.; Zhang, C.G.; Hou, W.G.; Sun, D.J.; Wang, G.T. Study on the preparation and structure of positive sol composed of mixed metal hydroxide. Colloid Polym. Sci. 1996, 274, 860-865. [CrossRef]

44. Yuan, X.; Wang, Y.; Zhou, C. One-pot hydrothermal synthesis of graphene/MgAl-LDH composite by urea hydrolysis. Nanomater. Energy 2014, 3, 30-38. [CrossRef]

45. Ahmed, N.; Shibata, Y.; Taniguchi, T.; Izumi, Y. Photocatalytic conversion of carbon dioxide into methanol using zinc-copper-M(III) (M = aluminum, gallium) layered double hydroxides. J. Catal. 2011, 279, 123-135. [CrossRef]

46. Ahmed, N.; Morikawa, M.; Izumi, Y. Photocatalytic conversion of carbon dioxide into methanol using optimized layered double hydroxide catalysts. Catal. Today 2012, 185, 263-269. [CrossRef]

47. Iguchi, S.; Teramura, K.; Hosokawa, S.; Tanaka, T. Photocatalytic conversion of $\mathrm{CO}_{2}$ in an aqueous solution using various kinds of layered double hydroxides. Catal. Today 2015, 251, 140-144. [CrossRef]

48. Iguchi, S.; Teramura, K.; Hosokawa, S.; Tanaka, T. Effect of the chloride ion as a hole scavenger on the photocatalytic conversion of $\mathrm{CO}_{2}$ in an aqueous solution over Ni-Al layered double hydroxides. Phys. Chem. Chem. Phys. 2015, 17, 17995-18003. [CrossRef]

49. Iguchi, S.; Teramura, K.; Hosokawa, S.; Tanaka, T. Photocatalytic conversion of $\mathrm{CO}_{2}$ in water using fluorinated layered double hydroxides as photocatalysts. Appl. Catal. A Gen. 2016, 521, 160-167. [CrossRef]

50. Flores-Flores, M.; Luévano-Hipólito, E.; Martínez, L.M.T.; Morales-Mendoza, G.; Gómez, R. Photocatalytic $\mathrm{CO}_{2}$ conversion by $\mathrm{MgAl}$ layered double hydroxides: Effect of $\mathrm{Mg}^{2+}$ precursor and microwave irradiation time. J. Photochem. Photobiol. A Chem. 2018, 363, 68-73. [CrossRef]

51. Wang, K.; Zhang, L.; Su, Y.; Shao, D.; Zeng, S.; Wang, W. Photoreduction of carbon dioxide of atmospheric concentration to methane with water over CoAl-layered double hydroxide nanosheets. J. Mater. Chem. A 2018, 6, 8366-8373. [CrossRef]

52. Tokudome, Y.; Fukui, M.; Iguchi, S.; Hasegawa, Y.; Teramura, K.; Tanaka, T.; Takemoto, M.; Katsura, R.; Takahashi, M. A nanoLDH catalyst with high $\mathrm{CO}_{2}$ adsorption capability for photo-catalytic reduction. J. Mater. Chem. A 2018, 6, 9684-9690. [CrossRef]

53. Gao, G.; Zhu, Z.; Zheng, J.; Liu, Z.; Wang, Q.; Yan, Y. Ultrathin magnetic Mg-Al LDH photocatalyst for enhanced $\mathrm{CO}_{2}$ reduction: Fabrication and mechanism. J. Colloid Interface Sci. 2019, 555, 1-10. [CrossRef] [PubMed]

54. Bai, S.; Wang, Z.; Tan, L.; Waterhouse, G.I.N.; Zhao, Y.; Song, Y.F. 600 nm Irradiation-Induced Efficient Photocatalytic $\mathrm{CO}_{2}$ Reduction by Ultrathin Layered Double Hydroxide Nanosheets. Ind. Eng. Chem. Res. 2020, 59, 5848-5857. [CrossRef]

55. Xiong, X.; Zhao, Y.; Shi, R.; Yin, W.; Zhao, Y.; Waterhouse, G.I.N.; Zhang, T. Selective photocatalytic $\mathrm{CO}_{2}$ reduction over $\mathrm{Zn}$-based layered double hydroxides containing tri or tetravalent metals. Sci. Bull. 2020, 65, 987-994. [CrossRef]

56. Wang, Z.; Xu, S.M.; Tan, L.; Liu, G.; Shen, T.; Yu, C.; Wang, H.; Tao, Y.; Cao, X.; Zhao, Y.; et al. 600 nm-driven photoreduction of $\mathrm{CO}_{2}$ through the topological transformation of layered double hydroxides nanosheets. Appl. Catal. B Environ. 2020, 270, 118884. [CrossRef] 
57. Zhao, H.; Xu, J.; Liu, L.; Rao, G.; Zhao, C.; Li, Y. CO $\mathrm{CO}_{2}$ photoreduction with water vapor by Ti-embedded $\mathrm{MgAl}$ layered double hydroxides. J. $\mathrm{CO}_{2}$ Util. 2016, 15, 15-23. [CrossRef]

58. Iguchi, S.; Hasegawa, Y.; Teramura, K.; Kidera, S.; Kikkawa, S.; Hosokawa, S.; Asakura, H.; Tanaka, T. Drastic improvement in the photocatalytic activity of $\mathrm{Ga}_{2} \mathrm{O}_{3}$ modified with $\mathrm{Mg}$-Al layered double hydroxide for the conversion of $\mathrm{CO}_{2}$ in water. Sustain. Energy Fuels 2017, 1, 1740-1747. [CrossRef]

59. Chong, R.; Su, C.; Du, Y.; Fan, Y.; Ling, Z.; Chang, Z.; Li, D. Insights into the role of MgAl layered double oxides interlayer in $\mathrm{Pt} / \mathrm{TiO}_{2}$ toward photocatalytic $\mathrm{CO}_{2}$ reduction. J. Catal. 2018, 363, 92-101. [CrossRef]

60. Wang, X.; Wang, Z.; Bai, Y.; Tan, L.; Xu, Y.; Hao, X.; Wang, J.; Mahadi, A.H.; Zhao, Y.; Zheng, L.; et al. Tuning the selectivity of photoreduction of $\mathrm{CO}_{2}$ to syngas over $\mathrm{Pd} /$ layered double hydroxide nanosheets under visible-light up to $600 \mathrm{~nm}$. J. Energy Chem. 2020, 46, 1-7. [CrossRef]

61. Zhao, C.; Liu, L.; Rao, G.; Zhao, H.; Wang, L.; Xu, J.; Li, Y. Synthesis of novel MgAl layered double oxide grafted $\mathrm{TiO}_{2}$ cuboids and their photocatalytic activity on $\mathrm{CO}_{2}$ reduction with water vapor. Catal. Sci. Technol. 2015, 5, 3288-3295. [CrossRef]

62. Kumar, S.; Isaacs, M.A.; Trofimovaite, R.; Durndell, L.; Parlett, C.M.A.; Douthwaite, R.E.; Coulson, B.; Cockett, M.C.R.; Wilson, K.; Lee, A.F. P25@CoAl layered double hydroxide heterojunction nanocomposites for $\mathrm{CO}_{2}$ photocatalytic reduction. Appl. Catal. B Environ. 2017, 209, 394-404. [CrossRef]

63. Tang, L.; Chen, R.; Meng, X.; Lv, B.; Fan, F.; Ye, J.; Wang, X.; Zhou, Y.; Li, C.; Zou, Z. Unique homo-heterojunction synergistic system consisting of stacked $\mathrm{BiOCl}$ nanoplate/Zn-Cr layered double hydroxide nanosheets promoting photocatalytic conversion of $\mathrm{CO}_{2}$ into solar fuels. Chem. Commun. 2018, 54, 5126-5129. [CrossRef] [PubMed]

64. Yang, Y.; Wu, J.; Xiao, T.; Tang, Z.; Shen, J.; Li, H.; Zhou, Y.; Zou, Z. Urchin-like hierarchical

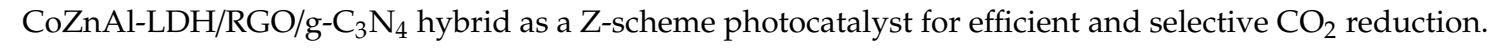
Appl. Catal. B Environ. 2019, 255, 117771. [CrossRef]

65. Ziarati, A.; Badiei, A.; Grillo, R.; Burgi, T. 3D Yolk@Shell TiO ${ }_{2-x} / \mathrm{LDH}$ Architecture: Tailored Structure for Visible Light $\mathrm{CO}_{2}$ Conversion. ACS Appl. Mater. Interfaces 2019, 11, 5903-5910. [CrossRef]

66. Jo, W.K.; Kumar, S.; Tonda, S. N-doped C dot/CoAl-layered double hydroxide/g- $\mathrm{C}_{3} \mathrm{~N}_{4}$ hybrid composites for efficient and selective solar-driven conversion of $\mathrm{CO}_{2}$ into $\mathrm{CH}_{4}$. Compos. Part B Eng. 2019, 176, 107212. [CrossRef]

67. Wu, Y.; Gong, Y.; Liu, J.; Chen, T.; Liu, Q.; Zhu, Y.; Niu, L.; Li, C.; Liu, X.; Sun, C.Q.; et al. Constructing $\mathrm{NiFe}-\mathrm{LDH}$ wrapped $\mathrm{Cu}_{2} \mathrm{O}$ nanocube heterostructure photocatalysts for enhanced photocatalytic dye degradation and $\mathrm{CO}_{2}$ reduction via Z-scheme mechanism. J. Alloys Compd. 2020, 831, 154723. [CrossRef]

68. Jiang, H.; Katsumata, K.I.; Hong, J.; Yamaguchi, A.; Nakata, K.; Terashima, C.; Matsushita, N.; Miyauchi, M.; Fujishima, A. Photocatalytic reduction of $\mathrm{CO}_{2}$ on $\mathrm{Cu}_{2} \mathrm{O}$-loaded $\mathrm{Zn}-\mathrm{Cr}$ layered double hydroxides. Appl. Catal. B Environ. 2018, 224, 783-790. [CrossRef]

69. Ye, T.; Huang, W.; Zeng, L.; Li, M.; Shi, J. $\mathrm{CeO}_{2-x}$ platelet from monometallic cerium layered double hydroxides and its photocatalytic reduction of $\mathrm{CO}_{2}$. Appl. Catal. B Environ. 2017, 210, 141-148. [CrossRef]

Publisher's Note: MDPI stays neutral with regard to jurisdictional claims in published maps and institutional affiliations.

(C) 2020 by the authors. Licensee MDPI, Basel, Switzerland. This article is an open access article distributed under the terms and conditions of the Creative Commons Attribution (CC BY) license (http://creativecommons.org/licenses/by/4.0/). 